\title{
Preliminary Safety Design Report for the Remote Handled Low-Level Waste Disposal Project
}

July 2012

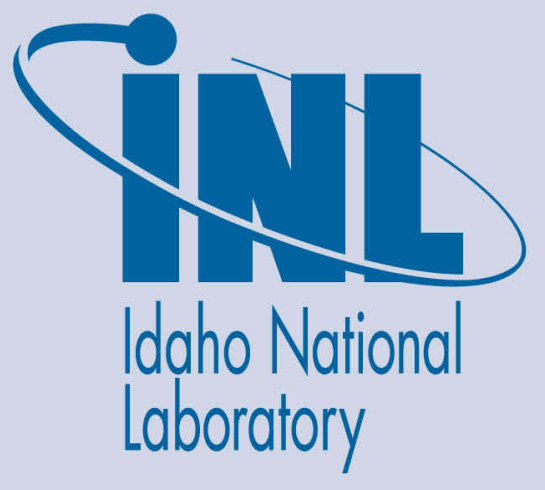

The INL is a U.S. Department of Energy National Laboratory operated by Battelle Energy Alliance 


\section{DISCLAIMER}

This information was prepared as an account of work sponsored by an agency of the U.S. Government. Neither the U.S. Government nor any agency thereof, nor any of their employees, makes any warranty, expressed or implied, or assumes any legal liability or responsibility for the accuracy, completeness, or usefulness, of any information, apparatus, product, or process disclosed, or represents that its use would not infringe privately owned rights. References herein to any specific commercial product, process, or service by trade name, trade mark, manufacturer, or otherwise, does not necessarily constitute or imply its endorsement, recommendation, or favoring by the U.S. Government or any agency thereof. The views and opinions of authors expressed herein do not necessarily state or reflect those of the U.S. Government or any agency thereof. 


\title{
Preliminary Safety Design Report for the Remote Handled Low-Level Waste Disposal Project
}

July 2012

\author{
Idaho National Laboratory \\ Idaho Falls, Idaho 83415
}

http://www.inl.gov

Prepared for the

U.S. Department of Energy

Office of Nuclear Energy

Under DOE Idaho Operations Office

Contract DE-AC07-05ID14517 


\title{
Preliminary Safety Design Report for the Remote Handled Low-Level Waste Disposal Project
}

\author{
INL/EXT-10-19054
}

Revision 0

June 2012

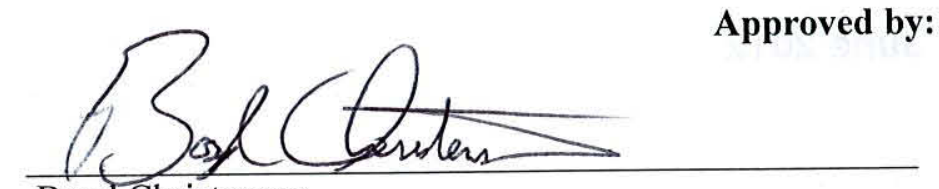

Boyd Christensen

INL Nuclear Safety Analyst

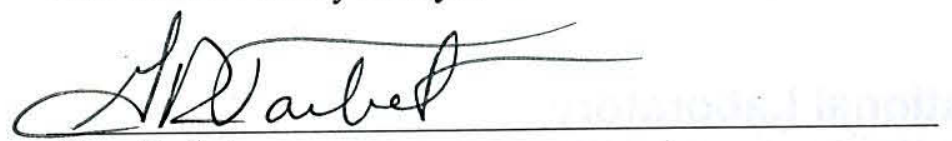

Gary Tarbet

Design Authority, RH LLW Disposal Project

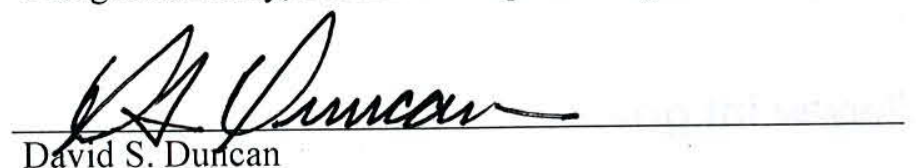

INL Project Manager

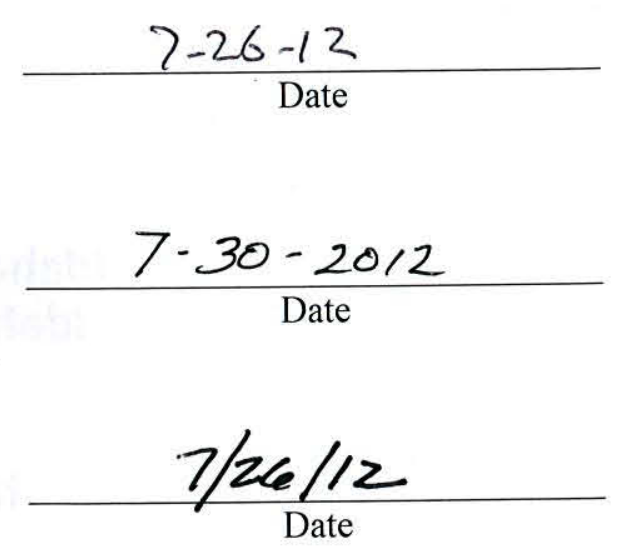


INL/EXT-10-19054

Revision 0

\begin{abstract}
A new onsite, remote-handled low-level waste disposal facility has been identified as the highest ranked alternative for providing continued, uninterrupted remote-handled low-level waste disposal for remote-handled low-level waste from the Idaho National Laboratory and for nuclear fuel processing activities at the Naval Reactors Facility. Historically, this type of waste has been disposed of at the Radioactive Waste Management Complex. Disposal of remote-handled low-level waste in concrete disposal vaults at the Radioactive Waste Management Complex will continue until the facility is full or until it must be closed in preparation for final remediation of the Subsurface Disposal Area (approximately at the end of Fiscal Year 2017).

This preliminary safety design report supports the design of an onsite remotehandled low-level waste disposal facility by providing an initial nuclear facility hazard categorization, discussing site characteristics that impact accident analysis, providing the facility and process information necessary to support the hazard analysis, identifying and evaluating potential hazards for processes associated with onsite handling and disposal of remote-handled low-level waste, and discussing the need for safety features that will become part of the facility design. This safety basis does not include the potential for offsite low-level waste shipments.
\end{abstract}




\section{CONTENTS}

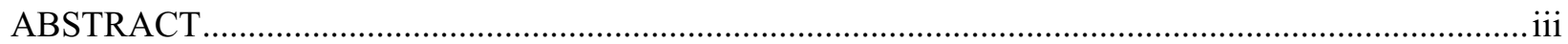

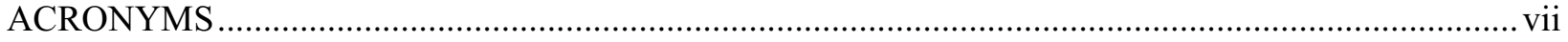

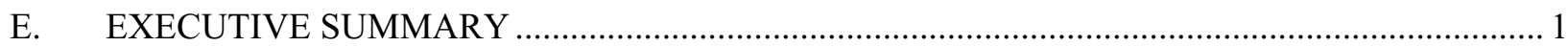

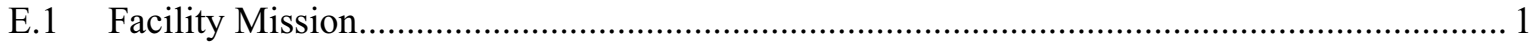

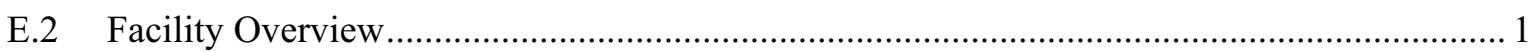

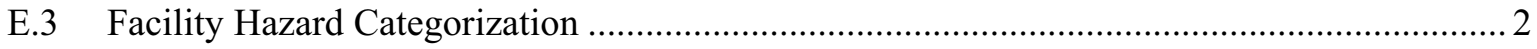

E.4 Safety Analysis Overview .................................................................................. 2

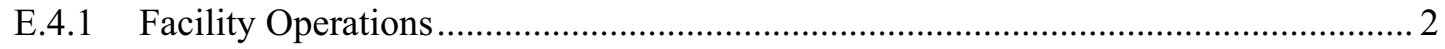

E.4.2 Design-Basis Accidents ................................................................................ 2

E.4.3 Preventive and Mitigative Engineered Features …................................................. 3

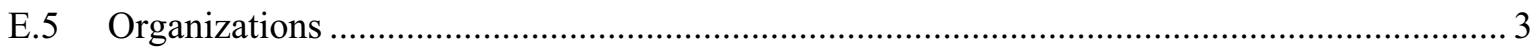

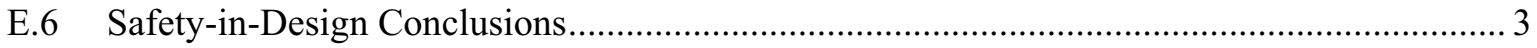

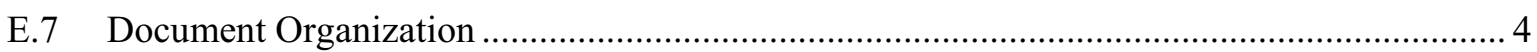

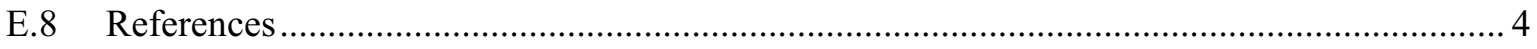

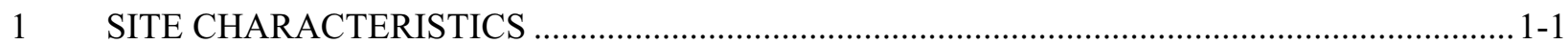

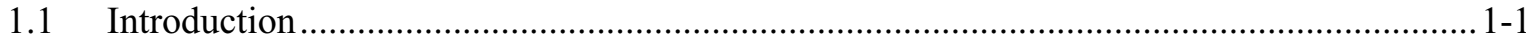

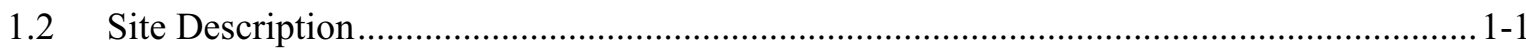

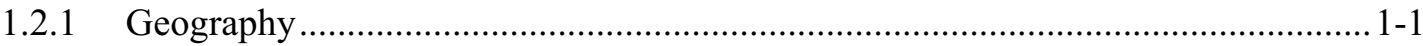

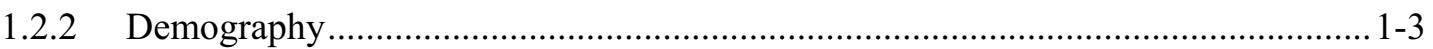

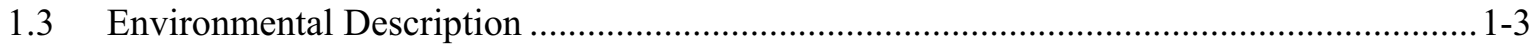

1.4 Natural Event Accident Initiators............................................................................ 1-3

1.5 Man-Made External Accident Initiators..................................................................... 1-3

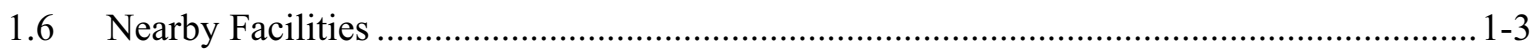

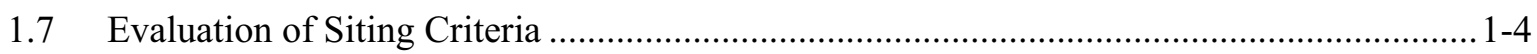

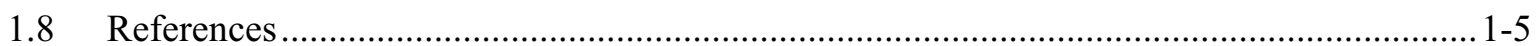

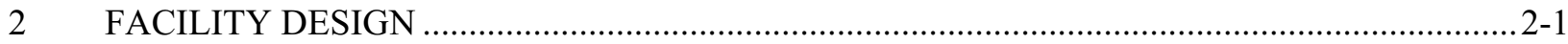

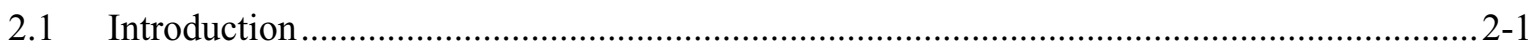

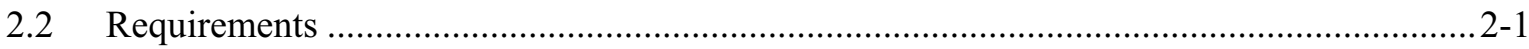

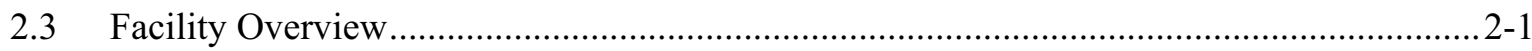

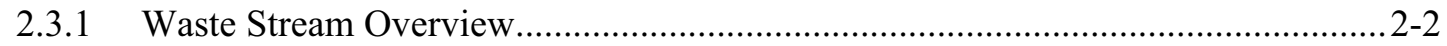

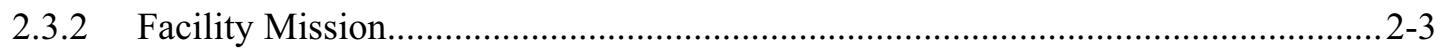

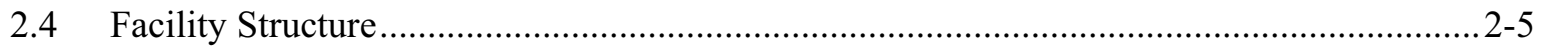

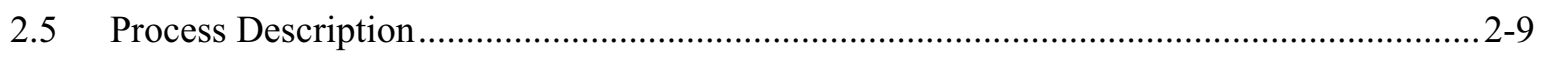

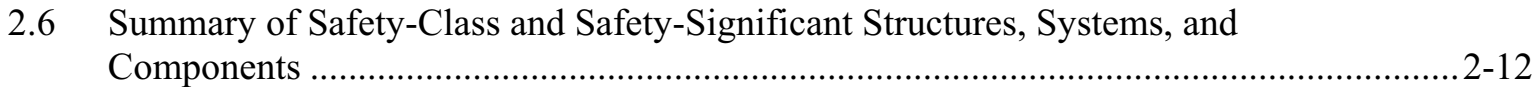

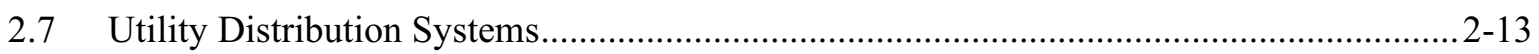

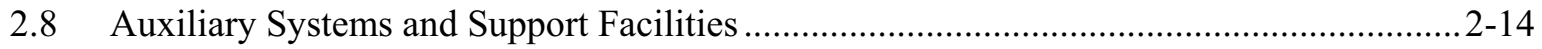

2.9 Design Provisions for Decontamination and Decommissioning .......................................2-15

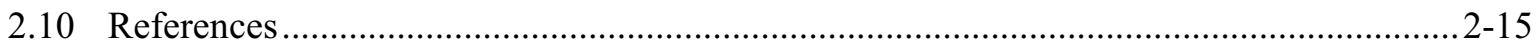




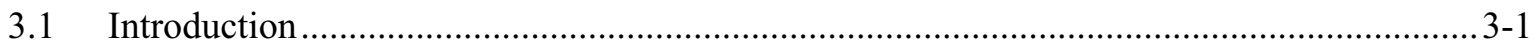

3.2 Hazard Analysis, Accident Analysis, Control Selection, and Classification

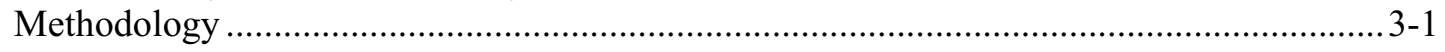

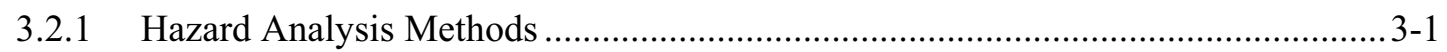

3.2.2 Accident Consequence Analysis Methods ........................................................ 3-1

3.2.3 Method for Analysis of Design-Basis Accidents ........................................................ 3-2

3.2.4 Control Selection and Classification Methods ........................................................ 3-3

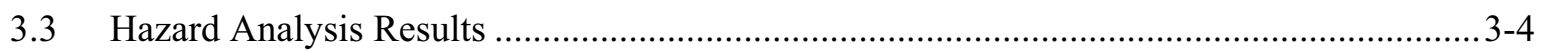

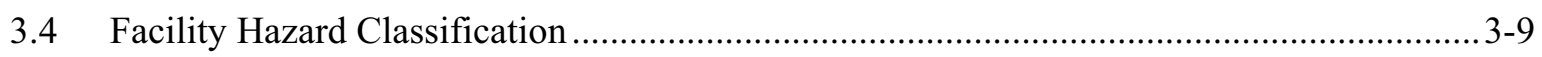

3.4.1 Hazardous Material Inventories ..........................................................................

3.4.2 Comparison of Inventories to Threshold Quantities .......................................... 3-10

3.5 Results of Analysis of Accidents ................................................................................

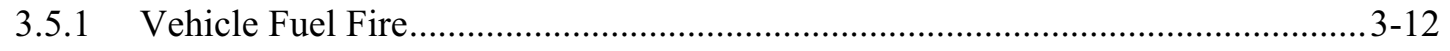

3.5.2 Container Drop Accident ............................................................................... $3-14$

3.5.3 Direct Radiation Exposure During Waste Container Handling ............................. 3-16

3.5.4 Severe Seismic Event.................................................................................... 3-18

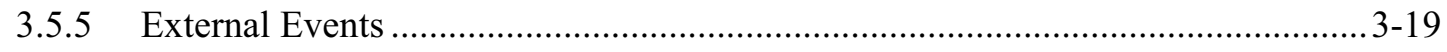

3.6 Summary of Significant Facility Worker Hazards and Controls ....................................... 3-19

3.7 Summary of Safety Functions and SSCs and SACs ..................................................... 3-19

3.8 Accidents Beyond the Design Basis ......................................................................... 3-21

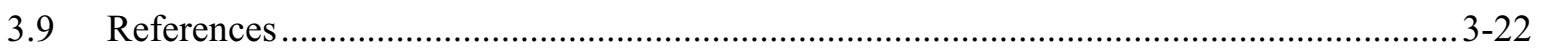

4 SAFETY STRUCTURES, SYSTEMS, AND COMPONENTS FOR PRELIMINARY

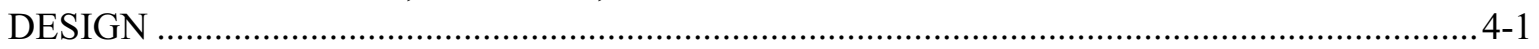

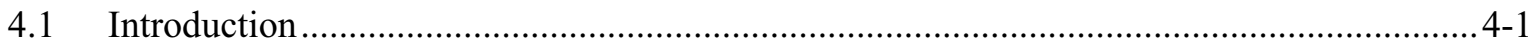

4.2 Safety-Class Structures, Systems, and Components ................................................... $4-1$

4.3 Safety-Significant Structures, Systems, and Components ............................................. 4-1

4.3.1 Vault Shield Plugs...................................................................................... $4-2$

4.3.2 Waste Container Transfer System Shielding ....................................................... 4-4

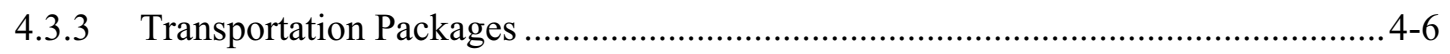

4.4 Specific Administrative Controls ............................................................................... $4-9$

4.4.1 Specific Procedures for Transferring Waste Containers with High Contact

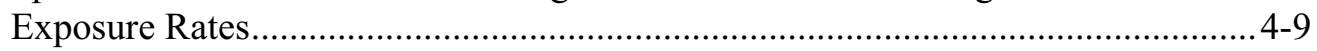

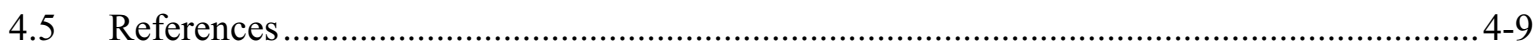

5 PRELIMINARY DERIVATION OF TECHNICAL SAFETY REQUIREMENTS......................5-1

6 DESIGN FOR THE PREVENTION OF INADVERTENT CRITICALITY ................................ 6-1

APPENDIX A.SAFETY MANAGEMENT PROGRAM ROADMAP ............................................... A-1

APPENDIX B.DESIGN APPROACH TO ADDRESS DOE ORDER 420.1B DESIGN REQUIREMENTS 


\section{FIGURES}

Figure 1-1. Map of INL and location of selected site within its boundary. ........................................... 1-2

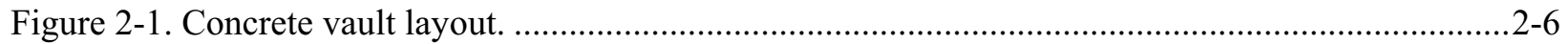

Figure 2-2. Proposed layout for the RH LLW disposal project. ........................................................2-6

Figure 2-3. Example waste container used inside the 55-ton scrap cask.............................................2-8

Figure 2-4. RH LLW disposal project engineered cover. ................................................................. 2-9

Figure 2-5. RH LLW disposal project process flow diagram. ..........................................................2-10

Figure 2-6. Waste container placement method at RWMC ............................................................2-11

Figure 2-7. 55-ton scrap cask used for transporting waste to a disposal facility. ................................2-12

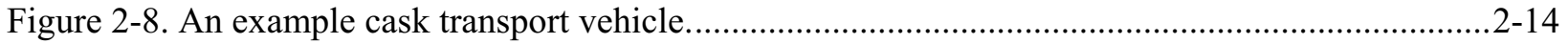

TABLES

Table 1-1.Summary of key evaluation areas for the identification of site selection criteria.....................1-4

Table 2-1. Waste streams proposed for the RH LLW disposal project...............................................2-2

Table 2-2. Waste stream and container/vault configurations..............................................................

Table 3-1.INL radiological risk evaluation guidelines. ..................................................................... $3-4$

Table 3-2. Preliminary hazards identified for the RH LLW disposal project. ........................................ 3-5

Table 3-3.Bounding radionuclide content for RH LLW disposal project containers. ............................3-10

Table 3-4. Sum of ratios of individual vault inventory to HC-2 TQs................................................ 3-11

Table 3-5. Release factors for RH LLW disposal project fire scenarios.............................................. 3-13

Table 3-6. Inhalation dose consequences for RH LLW disposal project fire scenarios. ........................3-13

Table 3-7. Release factors for RH LLW disposal project drop scenarios........................................... 3-15

Table 3-8. Inhalation dose consequences for container drop accident....................................................15

Table 3-9. Direct radiation exposure rates due to unshielded containers.................................................17

Table 3-10. Preliminary hazard controls for RH LLW disposal project..............................................3-20

Table 4-1. Safety-significant SSCs and performance criteria..............................................................4-2

Table A-1.Safety management program roadmap. ........................................................................ 1

Table B-2. Top-level DOE O 420.1B and DOE G 420.101 requirements compliance matrix.................... 7 


\section{ACRONYMS}

$\mathrm{AC}$

administrative control

ALARA as low as reasonably achievable

ARF

airborne release fraction

ATR

Advanced Test Reactor

BEA

Battelle Energy Alliance, LLC

$\mathrm{BR}$

breathing rate

CD-2

critical decision phase 2

CDR

conceptual design report

CED

committed effective dose

CIC

core internal changeout

CSDR

conceptual safety design report

CVAS

cask-to-vault adapting structure

DBA

design-basis accident

DC

deposition coefficient

DCF

dose conversion factor

D\&D

decontamination and decommissioning

DOE

Department of Energy

DOE-ID Department of Energy Idaho Operations Office

DR damage ratio

DSA documented safety analysis

EA environmental assessment

EG evaluation guideline

FCF Fuel Conditioning Facility

FONSI Finding of No Significant Impact

FTC Facility transfer cask

FY fiscal year

HC hazard category

HFEF Hot Fuel Examination Facility

IBC International Building Code

ICBO International Conference of Building Officials

INL Idaho National Laboratory

LCO limiting condition for operation

LOCA loss-of-coolant accident 
LLW low-level waste

LPF leak path factor

MAR material-at-risk

MFC Materials and Fuels Complex

NEPA National Environmental Policy Act

NNSA National Nuclear Security Administration

NOAA National Oceanic and Atmospheric Administration

$\mathrm{NPH}$ natural phenomena hazard

NRF Naval Reactors Facility

PDSA preliminary documented safety analysis

PHA preliminary hazards analysis

PSDR preliminary safety design report

RCRA Resource Conservation and Recovery Act

RF respirable fraction

$\mathrm{RH} \quad$ remote-handled

RH LLW Remote-Handled Low-Level Waste

RSAC radiological safety analysis computer

RSWF Radioactive Scrap and Waste Facility

RTA Reactor Test Area

RWMC Radioactive Waste Management Complex

SAC specific administrative control

SDA Subsurface Disposal Area

SDC seismic design category

SDS safety design strategy

SFHP spent fuel handling project

SNF spent nuclear fuel

SSC structure, system, and component

ST $\quad$ source term

TFR technical and functional requirement

TQ threshold quantity

TRU transuranic

TSR technical safety requirement

WAC waste acceptance criteria 
INL/EXT-10-19054

Revision 0

\section{E. EXECUTIVE SUMMARY}

This preliminary safety design report (PSDR) updates the information presented in the conceptual safety design report (CSDR) (INL 2010a) developed for the Remote-Handled Low-Level Waste (RH LLW) Disposal Project that will be located at Idaho National Laboratory (INL).In addition, this PSDR discusses site characteristics that impact accident analysis, provides the facility and process information necessary to support the hazard analysis, identifies and evaluates potential hazards for processes associated with onsite handling and disposal of RH LLW, and discusses the need for safety features that will become part of the facility design. This PSDR was prepared in accordance with Department of Energy (DOE)-STD-1189-2008, "Integration of Safety into the Design Process." This PSDR does not include the potential for offsite LLW shipments.

The information in this report is based upon the information contained in TFR-483, "Technical and Functional Requirements for the Remote-Handled Low-Level Waste Disposal Project," and SPC-1437, "Design-Build-Operate Performance Specification for the Remote-Handled Low-Level Waste Disposal Project." Since the design-build process will allow the bidders a level of latitude for design optimizations, their proposals for the project will be evaluated for design differences which will be properly reflected in the preliminary documented safety analysis (PDSA).

\section{E.1 Facility Mission}

On July 1, 2009, DOE approved a mission need statement for the INL RH LLW disposal project to develop replacement RH LLW disposal capability in support of INL's nuclear energy mission and the Naval Nuclear Propulsion Program (DOE-ID 2009). The continuing nuclear mission of the INL, associated ongoing and planned operations, and naval spent nuclear fuel (SNF) activities at the Naval Reactors Facility (NRF) require continued capability to appropriately dispose of RH LLW. Development of a new onsite disposal facility has been identified as the highest ranked alternative for providing continued, uninterrupted INL RH LLW disposal capability (INL 2010b), and the final site selection is documented in the environmental assessment (DOE-ID 2011) where a Finding of No Significant Impact (FONSI) was determined to be appropriate.

\section{E.2 Facility Overview}

The proposed RH LLW disposal project is anticipated to be designed, constructed, and operated similar to the RH LLW concrete disposal vaults currently in use in the Radioactive Waste Management Complex (RWMC). The vaults are anticipated to be constructed of reinforced, precast concrete cylinders stacked on end and placed in honeycomb-type arrays. A removable concrete plug is anticipated to be set on top of the stacked precast concrete cylinders to serve as a radiation shield and water barrier.

The facility is anticipated to be laid out in a manner to allow trucks entering the disposal facility to have full access to the unloading area adjacent to the disposal vaults. The crane and other miscellaneous equipment, required for completion of the transportation package-to-vault transfer operation, will be staged before arrival of the waste containers. The new facility will use these same methods and will set up the necessary equipment in a similar configuration as RWMC. Since there will be differences in operations, further operational details will be provided in later safety-basis documentation (i.e., PDSA and final DSA). Suggested controls will also be considered and finalized in later safety-basis documentation. 
The total number of vaults that will be constructed is based upon estimated projections of future waste quantities (TFR-483). The general layout in the conceptual design report (CDR) (INL 2010c) shows the areal extent of the vaults, as determined using a minimum vault height of $20 \mathrm{ft}$ that can accommodate disposal of multiple waste containers per vault depending on size of the container.

\section{E.3 Facility Hazard Categorization}

The RH LLW disposal project mission is to develop replacement RH LLW disposal capability in support of INL's nuclear energy mission and the Naval Nuclear Propulsion Program. This mission will be accomplished by providing separated, individual concrete disposal vaults. The total remote-handled LLW disposal project radioactive material inventory anticipated to be present in the facility at a given time will exceed the hazard category (HC)-2 threshold quantity (TQ) values for several radionuclides per DOE-STD-1027-92, "Hazard Categorization and Accident Analysis Techniques for Compliance with DOE Order 5480.23, Nuclear Safety Analysis Reports."

DOE-STD-1027 supplemental guidance provides for facility categorization modification in the final hazard categorization process, considering (1) alternative release fractions or (2) change in material subject to an accident due to facility features that preclude bringing material together or causing harmful interaction from a common severe phenomenon (facility segmentation). These provisions will be further evaluated during the development of the PDSA and final DSA per NS-18101, "INL Safety Analysis Process," to determine if modification to the preliminary facility hazard category is appropriate based on alternative release fractions or facility segmentation considerations. If the segmented facility consideration is successful, the facility may be categorized based on the contents of a single vault. Such a categorization may result in a reduced facility hazard category. The hazard categorization process is presented in Chapter 3.

\section{E.4 Safety Analysis Overview}

\section{E.4.1 Facility Operations}

The proposed RH LLW disposal project will provide concrete disposal vaults needed to dispose of RH LLW. Specifically, the proposed RH LLW disposal project will be designed to do the following:

- Provide a concrete vault disposal system that can accommodate transportation packages and waste containers for waste disposal of RH LLW generated at NRF, the Advanced Test Reactor (ATR) Complex, and other INL locations such as the Materials and Fuels Complex (MFC).

- Provide crane access areas to support the placement of waste materials into the vaults, as needed, that will support the combined weight of a loaded crane during placement (crane, transportation package, transportation package-to-vault adapter components, shielding/sealing plug, and waste containers).

- Place waste containers into vaults and cover with a vault shield plug assembly to provide the appropriate level of shielding and worker protection per radiation levels specified in DOE O 5400.5, "Radiation Protection of the Public and the Environment."

\section{E.4.2 Design-Basis Accidents}

On the basis of risk binning criteria, the postulated accidents that are considered design-basis accidents (DBAs) that are subjected to the detailed accident analysis process include: 
INL/EXT-10-19054

Revision 0

- Vehicle fuel fire (bounds all fire and explosion events)

- Container drop accident (bounds all radioactive material release events)

- Direct radiation exposure during waste container handling (representative for all direct radiation exposure events)

- Severe seismic event (representative for all natural phenomena hazard [NPH] events)

- External events (consequences bounded by other events).

\section{E.4.3 Preventive and Mitigative Engineered Features}

The following safety-significant structures, systems, and components (SSCs) were identified during the hazard and accident analysis process to protect facility workers from direct radiation exposure:

- Robust transportation package

- Waste container transfer system shielding

- Vault shield plug.

There were no safety-class SSCs identified. A single specific administrative control (SAC) requiring technical safety requirement (TSR) coverage was identified:

- Specific procedures for transferring waste containers with high contact exposure rates.

Facility inventory controls in the form of waste acceptance criteria (WAC) will ensure that inhalation dose consequences do not exceed evaluation guidelines (EGs).

\section{E.5 Organizations}

The DOE Idaho Operations Office (DOE-ID) is responsible for all operations at the INL. Battelle Energy Alliance (BEA), LLC, is the current management and operating contractor for the INL and is responsible for design, construction, operation, and maintenance of the RH LLW disposal project.

\section{E.6 Safety-in-Design Conclusions}

The safety analysis for the RH LLW disposal project and its operations, as documented here, demonstrates that public and worker health and safety and the environment are adequately protected by the safety functions that are part of the RH LLW disposal project design. Protection is provided by the safety-significant SSCs that govern RH LLW disposal project operations as derived from the hazard and accident analysis.

The design-build concept will place milestones out of phase with standard project progression and provide for the potential for design optimization concepts causing re-evaluation of the PSDR. This risk is accounted for in the safety design strategy (SDS) (INL 2010d) and will be mitigated through the tailoring strategy. 
INL/EXT-10-19054

Revision 0

\section{E.7 Document Organization}

This PSDR is compliant with the requirements of 10 CFR 830, "Nuclear Safety Management," Subpart B, "Safety Basis Requirements," and is written in a format that follows the DOE guidelines specified in DOE-STD-1189-2008.

\section{E.8 References}

10 CFR 830, "Nuclear Safety Management," Subpart B, "Safety Basis Requirements," Code of Federal Regulations, Office of the Federal Register, January 2001.

DOE-ID, 2009, Mission Need Statement for the Idaho National Laboratory Remote-Handled Low-Level Waste Disposal Project, DOE/ID-11364, Idaho National Laboratory, June 2009.

DOE-ID, 2011, Environmental Assessment for the Replacement Capability for Disposal of RemoteHandled Low-Level Radioactive Waste Generated at the Department of Energy's Idaho Site, DOE/EA-1793, Idaho National Laboratory, December 2011.

DOE Order 5400.5, "Radiation Protection of the Public and the Environment," Change 2, U.S. Department of Energy, January 1993.

DOE-STD-1027-92, "Hazard Categorization and Accident Analysis Techniques for Compliance with DOE Order 5480.23, Nuclear Safety Analysis Reports," U.S. Department of Energy, September 1997.

DOE-STD-1 189-2008, “Integration of Safety into the Design Process," U.S. Department of Energy, March 2008.

INL, 2010a, Conceptual Safety Design Report for the Remote-Handled Low-Level Waste Disposal Project, INL/EXT-09-17427, Idaho National Laboratory, Rev. 1, April 2010.

INL, 2010b, Remote-handled Low-level Waste Disposal Project Alternatives Analysis, INL/EXT-0917152, Idaho National Laboratory, April 2010.

INL, 2010c, Conceptual Design Report for the Remote Handled Low-Level Waste Disposal Project," INL/EXT-07-12901, Idaho National Laboratory, April 2010.

INL, 2010d, Safety Design Strategy for the Remote-Handled Low-Level Waste Disposal Project, INL/EXT-09-17117, Idaho National Laboratory, Rev. 31, April 2010 $\underline{\text { July } 2012 .}$

NS-18101, "INL Safety Analysis Process," current revision.

SPC-1437, "Design-Build-Operate Performance Specification for the Remote-Handled Low-Level Waste Disposal Project,” Rev. 0, January 2012.

TFR-483, "Remote-Handled Low-Level Waste Disposal Project,” Rev. 4, January 2012. 
INL/EXT-10-19054

Revision 0

\section{SITE CHARACTERISTICS}

\subsection{Introduction}

A description of the INL site characteristics important to understanding the safety basis of the RH LLW disposal project is contained in SAR-400, "INL Standardized Safety Analysis Report," Chapter 1, "Site Characteristics." Chapter 1 (SAR-400) is referenced in this chapter for descriptions of the INL site characteristics. Specific site characteristics that directly affect the design or the hazard and accident analysis of RH LLW disposal project are identified in this chapter, as necessary.

A siting study has been conducted to support the National Environmental Policy Act (NEPA) process that considered possible locations within the INL that are best suited for locating the proposed facility. The siting study used a five-step process to identify, screen, evaluate, score, and rank multiple sites located across the INL (INL 2010). The site selected for the RH LLW disposal project is documented in the environmental assessment (EA), (DOE 2011), "Environmental Assessment for the Replacement Capability for Disposal of Remote-Handled Low-Level Radioactive Waste Generated at the Department of Energy's Idaho Site," with a FONSI being determined to be appropriate. The site is located approximately 0.5 mile southwest of the ATR Complex as shown in Figure 1-1.

\subsection{Site Description}

A site description of the INL and the RH LLW disposal project site, including pertinent information on regional and INL geography, off-site and on-site demography, and regional and local land use, is contained in Chapter 1 of SAR-400 and in the siting study (INL 2010a).

\subsubsection{Geography}

The RH LLW disposal project site has a 45-acre parcel within which a properly sized site will allow for adequate road access for unloading operations for the facility. The site is located in an undisturbed area with existing unpaved road access and is located within 0.25 mile of an accessible paved roadway. A power line is located approximately 1 mile to the east. A major utility line is located approximately 0.5 mile to the west. Surficial sediment thickness, determined from wells in the vicinity of the site, ranges from 26 to $58 \mathrm{ft}$, which is more than adequate to support facility design and construction options. It also has excellent subsurface characteristics to impede downward migration of radionuclides and is located away from potential volcanic hazards.

There are some geotechnical and characterization data from ATR construction activities that may be applicable at this location. The site is outside of aquifer recharge zones and perched water. It is located outside the 1,000-year flood and is not in the ancestral Lake Terreton boundary. However, it is near a perched water zone. The site is not located on the Sagebrush-Steppe Ecosystem Reserve and is not close to vegetation transects. 

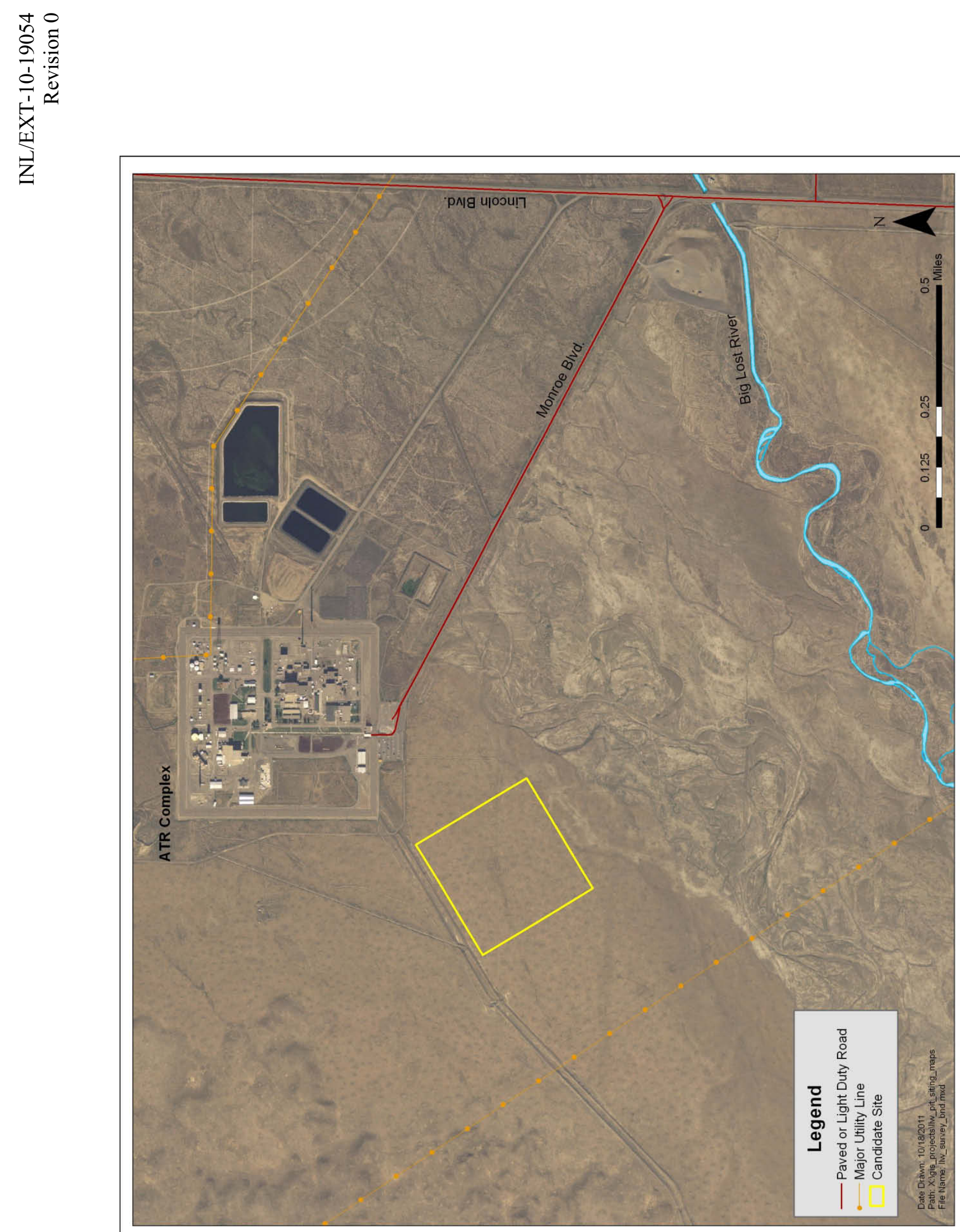

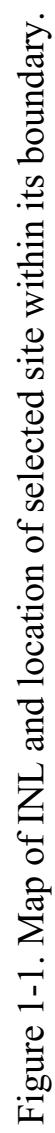


INL/EXT-10-19054

Revision 0

\subsubsection{Demography}

Not required for a PSDR per DOE-STD-1189-2008.

\subsection{Environmental Description}

Chapter 1 of SAR-400 contains descriptions of regional and local meteorology, hydrology (surface water and groundwater), and geology. The descriptions of site meteorology, hydrology, and geology in SAR-400 provide the basis for identifying and defining NPHs important to the safety analysis (see Section 1.4). Meteorological data from observation stations at the INL maintained by the National Oceanic and Atmospheric Administration (NOAA) provides the basis for atmospheric dispersion modeling required for the accident consequence analysis in Chapter 3.

\subsection{Natural Event Accident Initiators}

Specific natural phenomena threats (hazards) that are potential accident initiators for INL facilities are identified in Chapter 1 of SAR-400, which also lists the design criteria for these NPHs that are considered in evaluating potential accident initiators for RH LLW disposal project operations. NPHs directly applicable to the RH LLW disposal project are addressed in Chapter 3.

\subsection{Man-Made External Accident Initiators}

External, man-made threats, exclusive of sabotage and terrorism, ${ }^{a}$ that could be accident initiators for the RH LLW disposal project are identified and evaluated in Chapter 3 of this PSDR. Based on an assessment of aircraft impact probabilities at the MFC, an aircraft crash into the RH LLW disposal project is considered beyond extremely unlikely (probability of $<10^{-6}$ per year) when considered as an accident initiator in Chapter 3 (EDF-6437 and DOE 1996). External, man-made threats identified for evaluation as a part of the RH LLW disposal project operation hazard and accident analyses are a range fire and an adjacent facility fire.

\subsection{Nearby Facilities}

No postulated events identified and evaluated in Chapter 3 involving the RH LLW disposal project could negatively impact nearby INL facilities other than a possible evacuation due to a release of radioactive material. The INL site emergency plan addresses postulated accidents. These emergency preparedness plans are described in Chapter 15, "Emergency Preparedness Program," of SAR-400.

Refer to Section 1.7, "Nearby Facilities," (SAR-400) for a further description of nearby facilities that could be affected by accidents in the RH LLW disposal project or could adversely impact the RH LLW disposal project. As documented in the siting study (INL 2010a), the RH LLW disposal project site is located in a core infrastructure area but is well away from the explosive test area.

The site is approximately 0.5 mile southwest of the ATR Complex. The maximum dose from a hypothetical large break loss-of-coolant accident (LOCA) at the ATR is $~ 7.5$ rem at the Reactor Test Area (RTA) exclusion zone as documented in SAR-153, "Upgraded Final Safety Analysis Report for the Advanced Test Reactor." At a distance of 0.5 mile from the exclusion zone, this dose is less than the EGs

a. The analysis of postulated accidents caused by sabotage and terrorism is not within the scope of this PSDR. Identifying and controlling the risk of potential sabotage and terrorism threats at INL is the responsibility of INL security, and malevolent acts are addressed in the hazard assessment and response plans of the Emergency Preparedness Program. 
INL/EXT-10-19054

Revision 0

for an extremely unlikely event, and would not adversely impact the RH LLW disposal project beyond a possible need for evacuation.

\subsection{Evaluation of Siting Criteria}

As delineated in the siting study (INL 2010a), previous INL siting studies provided examples of various methods used for development and application of evaluation criteria and ranking strategies for site selection. Although these studies were conducted to evaluate sites for different types of facilities, they each identified numerous onsite candidate sites with a range of individual characteristics. Based on the analysis of previous siting studies, five key areas emerged as the primary contributors to development of site evaluation criteria. The criteria were developed from the synthesis of information and requirements from the following areas:

1. Regulations

2. Key assumptions

3. Conceptual design

4. Facility performance

5. Previous siting study criteria.

The first key evaluation area (regulations) sets the regulatory framework for siting a RH LLW disposal project to meet DOE requirements. The second and third areas (key assumptions and conceptual design) include facility-specific features related to type and volume of waste, geometry of the disposal system (vaults), and facility needs in terms of utilities and support infrastructure. The fourth area (facility performance) draws requirements from regulations and DOE Orders and considers, in large part, the physical setting of each location (i.e., geology, hydrology, natural resources, and natural phenomena hazards). The fifth area (previous siting study criteria) provides examples of evaluation criteria developed during the siting of other facilities at INL. The previous studies also identified and provided characterization data for a number of sites across INL that can be considered as candidate locations for a RH LLW disposal project disposal facility. Table 1-1 summarizes the resultant drivers drawn from review of the five areas.

Table 1-1.Summary of key evaluation areas for the identification of site selection criteria.

\begin{tabular}{|c|c|}
\hline Key Site Evaluation Areas & Contribution to Development of Selection Criteria \\
\hline \multirow{5}{*}{ 1. Regulations } & - DOE O 435.1, 430.1B, and 420.1 (with manuals, guides, and standards) \\
\hline & $\begin{array}{l}\text { - } 10 \text { CFR } 61.40 \text { and } 61.50 \text { (not required for a DOE facility but useful for criteria } \\
\text { development) }\end{array}$ \\
\hline & $\begin{array}{l}\text { - Applicable federal laws, executive orders, and implementing regulations (NEPA, } \\
\text { Clean Air Act; Endangered Species Act; and Historical, Tribal, and Cultural } \\
\text { Resources) }\end{array}$ \\
\hline & - Annualized waste generation rate of approximately $3,108 \mathrm{ft}^{3}$ per year \\
\hline & $\begin{array}{l}\text { - Waste type (RH LLW activated metals, ion-exchange resins, and other waste } \\
\text { streams) }\end{array}$ \\
\hline
\end{tabular}


Table 1-1.Summary of key evaluation areas for the identification of site selection criteria.

\begin{tabular}{|c|c|}
\hline Key Site Evaluation Areas & Contribution to Development of Selection Criteria \\
\hline \multirow{4}{*}{ 2. Key assumptions } & $\begin{array}{l}\text { - Limitations on waste characteristics resulting from the performance assessment } \\
\text { will be no more restrictive than those for the existing onsite RH LLW disposal } \\
\text { facility (contributes to conceptual facility design requirements that impact } \\
\text { criteria selection) }\end{array}$ \\
\hline & $\begin{array}{l}\text { - A new DSA and performance assessment will be required for the facility } \\
\text { (contributes to a need for evaluation of current site data that impact criteria } \\
\text { selection) }\end{array}$ \\
\hline & $\begin{array}{l}\text { - Facility size requirements (e.g., minimum area of } 5 \text { acres positioned to allow for } \\
\text { longitudinal expansion with surficial soils at a depth of } 26 \text { to } 58 \mathrm{ft} \text { ) }\end{array}$ \\
\hline & - Utilities (beneficial if power and water are available, but not mandatory) \\
\hline \multirow{4}{*}{ 3. Conceptual design } & $\begin{array}{l}\text { - Haul route and access roads (e.g., safe transport of anticipated loads and turning } \\
\text { radius) }\end{array}$ \\
\hline & $\begin{array}{l}\text { - Seismic design category (SDC) } 1 \text { [seismic design criterion per DOE-STD-1189- } \\
2008 \text { and the International Building Code(IBC)] }\end{array}$ \\
\hline & - Protection of the public (specifies three dose limit requirements) \\
\hline & - Facility requirements (e.g., access, power, water resources, and surface features) \\
\hline \multirow[b]{2}{*}{ 4. Facility performance } & $\begin{array}{l}\text { - Radionuclide Performance Assessment (specifies geological and hydrological } \\
\text { conditions that attenuate radionuclide migration and intruder assessments) }\end{array}$ \\
\hline & $\begin{array}{l}\text { - Site characteristics must be such that acceptable results can be obtained for the } \\
\text { NPH assessment (performance category-specific seismic and flooding } \\
\text { requirements for } 100,500 \text {, and 1,000-year events, with consideration of 10,000- } \\
\text { year events) }\end{array}$ \\
\hline \multirow{3}{*}{ 5. Previous siting studies } & - Examples of "Must" and "Want" criteria \\
\hline & - Identification of candidate sites (34 candidate sites identified) \\
\hline & - Evaluation methodology (three separate evaluation strategies identified) \\
\hline
\end{tabular}

\subsection{References}

DOE, 1996, “Accident Analysis for Aircraft Crash into Hazardous Facilities,” DOE-STD-3014-96, October 1996 (including Reaffirmation May 2006).

DOE, 2011, Environmental Assessment for the Replacement Capability for Disposal of Remote-Handled Low-Level Radioactive Waste Generated at the Department of Energy's Idaho Site (Including FONSI), DOE/EA-1793, Final, December 2011.

DOE-STD-1189-2008, “Integration of Safety into the Design Process," U.S. Department of Energy, March 2008.

EDF-6437, "Evaluation of the Aircraft Crash Frequency for the ZPPR Vault," Rev. 0, December 2005.

INL, 2010,Siting Study for the Remote-Handled Low-Level Waste Disposal Project, Rev. 2, INL/EXT-0712902, Idaho National Laboratory, October 2010. 
INL/EXT-10-19054

Revision 0

SAR-153, "Upgraded Final Safety Analysis Report for the Advanced Test Reactor," Idaho National Laboratory, Rev. 28, August 2010.

SAR-400, "INL Standardized Safety Analysis Report," Idaho National Laboratory, current revision. 
INL/EXT-10-19054

Revision 0

\section{FACILITY DESIGN}

\subsection{Introduction}

On July 1, 2009, DOE approved a mission need statement for the INL RH LLW disposal project to develop replacement RH LLW disposal capability in support of INL's nuclear energy mission and the Naval Nuclear Propulsion Program (DOE-ID 2009). The continuing nuclear mission of INL, associated ongoing and planned operations, and naval SNF activities at the NRF require continued capability to appropriately dispose of RH LLW. Development of a new onsite disposal facility has been identified as the highest ranked alternative for providing continued, uninterrupted INL RH LLW disposal capability as documented in the alternatives analysis (INL 2010a). The RH LLW Disposal Project will have an initial hazard categorization of a HC-2 nuclear facility; however, based on construction and disposed waste material characteristics, the hazard category for the facility may be downgraded to HC-3 (INL 2010b). Refer to Chapter 3 of this document and INL/EXT-09-17427, "Conceptual Safety Design Report for the Remote-Handled Low-Level Waste Disposal Project," (INL 2010b) for a more detailed discussion of hazard categorization.

This chapter describes the RH LLW disposal project, including the general design of principal SSCs and the RH LLW disposal process operations that are anticipated to be performed at the RH LLW disposal project. This chapter also includes a description of the utilities and auxiliary systems, including a summary description of the safety SSCs.

\subsection{Requirements}

The codes, standards, regulations, and DOE Orders applicable to this chapter for establishing adequate safety-in-design for the RH LLW disposal project are:

- $\quad 10$ CFR 830, "Nuclear Safety Management"

- DOE O 420.1B, "Facility Safety"

- DOE-STD-1189-2008. "Integrating Safety Into the Design Process"

- $\quad$ DOE-STD-3009-94, "Preparation Guide for U.S. Department of Energy Nonreactor Nuclear Facility Documented Safety Analysis"

- International Conference of Building Officials (ICBO), International Building Code (IBC, 2012), in effect at the time of the RH LLW disposal project construction

Detailed RH LLW disposal project codes, standards, regulations, and DOE Orders are delineated in technical and functional requirements (TFR-483, "Remote-Handled Low-Level Waste Project") and the CDR.

\subsection{Facility Overview}

The RH LLW disposal facility is projected to have an initial 20-year operating life commencing at the beginning of fiscal year (FY) 2018. The performance assessment (DOE-ID 2011) addresses responses beyond the operational life. 
INL/EXT-10-19054

Revision 0

\subsubsection{Waste Stream Overview}

The proposed RH LLW disposal project will be designed and constructed to support disposal of RH LLW streams generated at the Idaho Site. A summary of these waste streams is provided in Table 2-1.

Table 2-1. Waste streams proposed for the RH LLW disposal project.

\section{Activated metals}

- $\quad$ ATR: ATR produces activated metals during reactor core internal change-out (CIC) operations approximately once every 10 years. These components require time for decay before disposition and are in storage at the ATR Complex. Previous disposal of this waste stream was performed at RWMC using a cask that is no longer in use.

- $\quad$ NRF: NRF produces activated metals during routine operations. Currently, waste is disposed of in the RWMC vaults in 55-ton scrap cask carbon steel canisters. NRF will transition to stainless steel canisters before RHLLWDF is on-line. Future shipments will also include large concept cask stainless-steel liners.

- $\quad$ MFC: Activated metals with incidental quantities of debris will be generated from new missions and from processing of waste currently stored at MFC's Radioactive Scrap and Waste Facility (RSWF).

\section{Ion-exchange resins}

- $\quad$ ATR: ATR produces ion-exchange resin waste during routine pool and reactor operations. This waste is currently disposed of in NuPac 14-210L cask liners at the Nevada National Security Site.

- $\quad$ NRF: NRF produces resin waste during routine operations. Currently, the waste is disposed of in Type VII demineralizer tanks in the RWMC vaults. NRF will also be shipping larger ion-exchange resins from the new spent fuel handling project (SFHP) facility.

Ion-exchange resins from pool and reactor operations are generated at the ATR Complex and from pool operations at NRF. ATR ion-exchange resin is generated approximately four to six times annually from reactor loop and reactor ion-exchange systems. The generation rate depends on reactor operations and varies during the years when CICs are performed. The ion-exchange resin waste stream has typical contact exposure rates up to $15 \mathrm{R} / \mathrm{hr}$, although individual waste containers may have higher contact exposure rates.

ATR also produces activated metals during reactor CIC operations (approximately every ten years). These components require decay time before they can be handled for disposal and are currently in temporary storage at the ATR Complex. The activated metal waste streams have typical contact exposure rates up to $30,000 \mathrm{R} / \mathrm{hr}$ (neutron and gamma), although individual waste containers may have higher contact exposure rates.

NRF produces activated metals from examination of test components and during routine operations removing irradiated non-fuel components from spent nuclear fuel modules. The NRF activated metal waste streams may have typical contact exposure rates up to $60,000 \mathrm{R} / \mathrm{hr}$ (neutron and gamma), although individual waste containers may have higher contact exposure rates.

In addition, activated metals and other RH LLW streams are expected from new INL programs and from processing of RH LLW stored at RSWF. These materials can contain a variety of radionuclides and 
can have contact exposure rates up to $30,000 \mathrm{R} / \mathrm{hr}$ (neutron and gamma), although individual waste containers may have higher contact exposure rates.

Specific waste streams and container/vault configurations as described in TFR-483 are shown in Table 2-2.

Table 2-2. Waste stream and container/vault configurations.

\begin{tabular}{|l|c|c|}
\hline \multirow{2}{*}{ Waste Stream } & Container Designation & $\begin{array}{c}\text { Number of } \\
\text { Containers per } \\
\text { vault }\end{array}$ \\
\hline \multirow{2}{*}{ NRF activated metals } & 55-ton cask liner & 2 \\
\cline { 2 - 3 } NRF resins & New concept container & 1 \\
\hline & 55-ton cask liner & 2 \\
\hline ATR activated metals & $\begin{array}{c}\text { Single-contained } 316 \mathrm{~L} \\
\text { HFEF-5 style cask liner }\end{array}$ & 2 \\
\hline \multirow{2}{*}{ ATR resins } & $\begin{array}{c}\text { NuPac 14/210L 316 L resin } \\
\text { liner }\end{array}$ & 2 \\
\hline MFC activated metals & HFEF-5 cask liner & 2 \\
\hline \multirow{2}{*}{ MFC legacy waste (RSWF) } & $\begin{array}{c}316 \text { Stainless Steel “24- } \\
\text { over-16” cask liner in } \\
\text { modified FTC cask }\end{array}$ & 1 \\
\hline MFC legacy waste (SN cans) & HFEF-5 cask liner & 2 \\
\hline MFC future (FCF) & HFEF-5 cask liner & 2 \\
\hline MFC future (HFEF) & HFEF-5 cask liner & 2 \\
\hline
\end{tabular}

\subsubsection{Facility Mission}

INL-generated radioactive waste has been disposed of at RWMC since 1977. RWMC disposal practices have evolved over time, including changes in the disposal facility, waste treatment, and containers. Current disposal operations within the Subsurface Disposal Area (SDA) are limited to subsurface burial of INL-generated LLW. Waste emplaced in the SDA is classified as either remote- or contact-handled LLW, depending on radiation levels.

Providing continued disposal capability for RH LLW supports the Office of Nuclear Energy, Science, and Technology's mission "to lead the DOE investment in the development and exploration of advanced nuclear science and technology." Without established, viable RH LLW disposal capability, ongoing and future Office of Nuclear Energy, Science, and Technology programs at INL will be adversely impacted as RH LLW disposal options will need to be considered on a program-by-program basis, resulting in increased costs and schedule. The lack of RH LLW disposal capability also may impede DOE's ability to initiate new programs at the INL.

RH LLW disposal capability is also critical to meeting the National Nuclear Security Administration's (NNSA's) mission to "provide the United States Navy with safe, militarily effective nuclear propulsion plants and to ensure the safe and reliable operation of those plants." All SNF from the 
INL/EXT-10-19054

Revision 0

Navy's nuclear-powered fleet is sent to NRF for examination, processing, dry storage, and eventual shipment to a permanent geologic repository. A reliable disposal path for RH LLW generated during SNF handling and packaging operations is essential to NRF's continued receipt and processing of Navy SNF and to the Naval Nuclear Propulsion Program as well as national security. The mission need statement for the INL RH LLW disposal project, created as a result of evaluating INL-generated LLW disposal options, is as follows:

The INL will develop replacement remote-handled low-level waste disposal capability ... to support cost-effective, efficient operations in support of INL's nuclear energy mission and the Naval Nuclear Propulsion Program. Such disposal capability is required to enhance ongoing Departmental and National mission-based research, defense, and energy programs.

The proposed RH LLW disposal project will provide concrete disposal vaults needed to dispose of RH LLW. Specifically, the proposed RH LLW disposal project is anticipated to be designed to do the following:

- Provide a precast concrete vault disposal system that may accommodate waste canisters, containers, and/or stainless steel liners as described in Table 2-1 (e.g., resins and activated metals generated at NRF and 60-in.-diameter waste containers anticipated for future use).

- Provide a precast concrete vault disposal system that can accommodate waste canisters that are anticipated to be used for disposal of RH LLW activated metals generated at ATR, MFC, and from new missions, including processing of waste currently in storage at RSWF.

- Accommodate the use of existing casks and cask trailers to minimize the impact to generator facilities.

- Accommodate the existing NRF 55-ton scrap cask RH loading equipment (such as the remoteoperated hoist system, platforms, and lifting equipment). The cask-to-vault adapting structure (CVAS) may be modified for use with the new vaults or may be replaced.

- Provide support equipment needed to unload waste canisters from the HFEF-5 and NuPac 14-210L casks.

- Accommodate future NRF new waste cask RH loading equipment (such as the remote-operated hoist system, platforms, CVAS, and lifting equipment).

- Accommodate the existing Manitowoc 3900w crane and new waste cask and design the RH LLW facility to accommodate both the existing and any future crane, as applicable.

- Provide road access that may accommodate anticipated loads from cask transport vehicles. 
INL/EXT-10-19054

Revision 0

- Place cask liners into vaults while providing the appropriate level of shielding and worker protection.

$\circ \quad$ A new waste cask will be designed and built to be used at NRF. The 55-ton scrap cask is currently utilized for shipment of NRF RH LLW. A new process is in the early stages of development and will result in the fabrication of a new waste cask system to supplement the 55-ton cask. This new waste cask will likely be constructed of stainless steel and will have similar performance functions and shielding properties as the 55-ton scrap cask. The dimensions will be approximately $60 \mathrm{in}$. in diameter and $170 \mathrm{in.} \mathrm{in} \mathrm{height.}$

- Provide a vault/plug assembly to provide shielding, minimize entry of water into the vaults, and allow drainage of any moisture or condensate that may accumulate within a vault.

- Allow access to individual vaults without disturbing adjacent vaults.

- Provide crane access areas to support placement of waste materials into the vaults, as needed, which will support the combined weight of a loaded crane during placement. The total weight would include the crane, cask, cask-to-vault adapter components, shielding/sealing plug, and cask liners.

- Provide shielding sufficient to reduce radiation levels on top of the vaults, when the plugs are in place, to levels specified in DOE O 5400.5, "Radiation Protection of the Public and the Environment."

- Provide administrative and maintenance space and infrastructure, including utilities, fencing, and site drainage and flood control to support operations.

\subsection{Facility Structure}

The conceptual design of the proposed RH LLW disposal project is documented in the CDR (INL 2010c), TFR-483, and SPC-1437. The RH LLW disposal project is anticipated to be designed and constructed similar to the RH LLW concrete disposal vaults currently in use in the RWMC SDA. This will accommodate, to the maximum extent possible, uninterrupted operations at the generating facilities and will capitalize on the operations experience and cost efficiencies of current RH LLW disposal practices. The vaults will be constructed of reinforced precast concrete cylinders stacked on end and placed in honeycomb-type arrays (see Figure 2-1). A removable concrete plug will be set on top of the stacked precast concrete cylinders to serve as a radiation shield and water barrier. The concrete will meet standards for resistance to degradation for freeze-thaw protection, leaching of calcium hydroxide, aggressive chemicals, reactions with aggregates, corrosion of embedded steel, elevated temperatures, irradiation, creep, shrinkage, and managing aging-related degradation effects. 
INL/EXT-10-19054

Revision 0

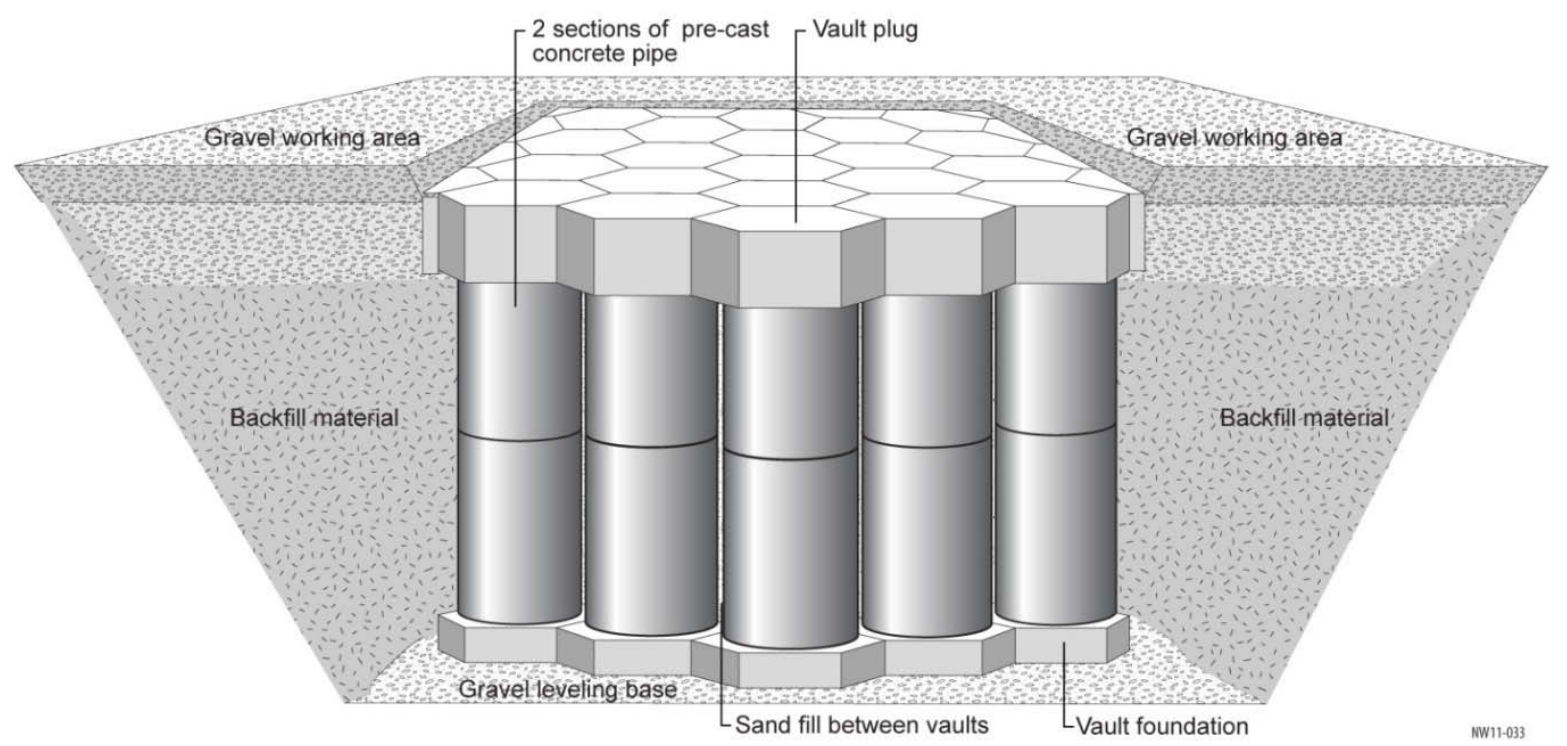

Figure 2-1. Concrete vault layout.

The proposed facility layout is based on the assumption that the facility is anticipated to be a standalone facility and will provide its own administration buildings and infrastructure to support disposal operations The RH LLW disposal project is projected to have an initial 20-year operational life, but the expansion for a 50 -year life is possible.

The facility is anticipated to be laid out in a manner to allow trucks entering the disposal facility to have have straight access to the unloading area next to the disposal vaults. In order to support operations, the crane and other miscellaneous equipment required for completion of the cask-to-vault transfer operation will be staged before arrival of the waste containers. Refer to

Figure 2-2Figure 2-2.

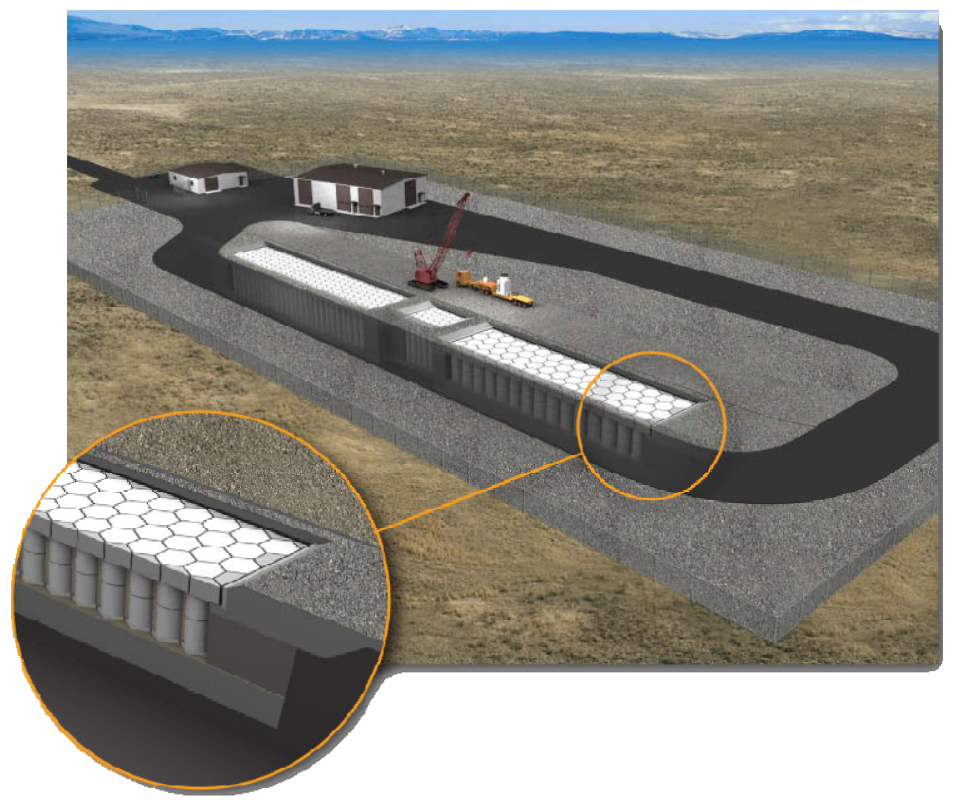


INL/EXT-10-19054

Revision 0

Figure 2-2. Proposed layout for the RH LLW disposal project.

The total number of vaults anticipated to be constructed will depend on the estimated projections of future waste quantities and the results of the Performance Assessment. The general layout in the conceptual design report shows the areal extent of the vaults, as determined using a vault depth that can accommodate disposal of two waste containers per vault. In this configuration, a minimum of 160 vaults will be needed initially for NRF waste, 60 vaults for ATR resins, and 23 vaults for activated metals from ATR processing of co-mingled, RH LLW currently stored in RSWF and new INL programs.

The following are major components of the proposed RH LLW disposal project:

- Vaults - The reinforced precast concrete vaults will be aligned vertically to allow multiple RH LLW containers to be stacked on top of the previous one inserted in a vertical orientation. Vaults used to dispose of NRF waste will be designed to interface with the existing CVAS (or a new/modified CVAS, if required) and the 55-ton scrap cask. Remaining vaults will be designed to interface with the appropriate transportation package and associated transfer system.

- Vault shield plugs - A removable concrete plug will be placed on top of each of the stacked cylinder vaults. The plug will serve as a radiation shield for placed waste and also will act as a water barrier to prevent surface water intrusion into the concrete vaults.

- Crane - The crane that that will be used at the RH LLW disposal project is the existing Manitowoc $3900 w$. Future operations may use a contractor-provided mobile boom crane or a full-span mobile gantry crane.

- Cask Transfer System-The cask transfer system will consist of all vehicles, casks, rigging equipment, CVAS, platforms, and/or shielding systems necessary to remove waste canisters from within the respective cask into the assigned vault. Several existing transfer systems shall interface with the vault configurations, including:

- $\quad$ NRF scrap cask

- NRF new waste cask

- $\quad$ NuPac 14-210L

- HFEF-5 cask

- $\quad$ Facility transfer cask (FTC).

- Waste container-RH LLW will be packaged into stainless steel waste containers at the generating facilities. One container at a time is shipped within a shielded transportation package from the generating facility to the disposal facility. Upon arrival at the appropriate vault array location, the waste container will be transferred from the transportation package into the concrete vault. An example of a waste container is shown in Figure 2-3. 
INL/EXT-10-19054

Revision 0

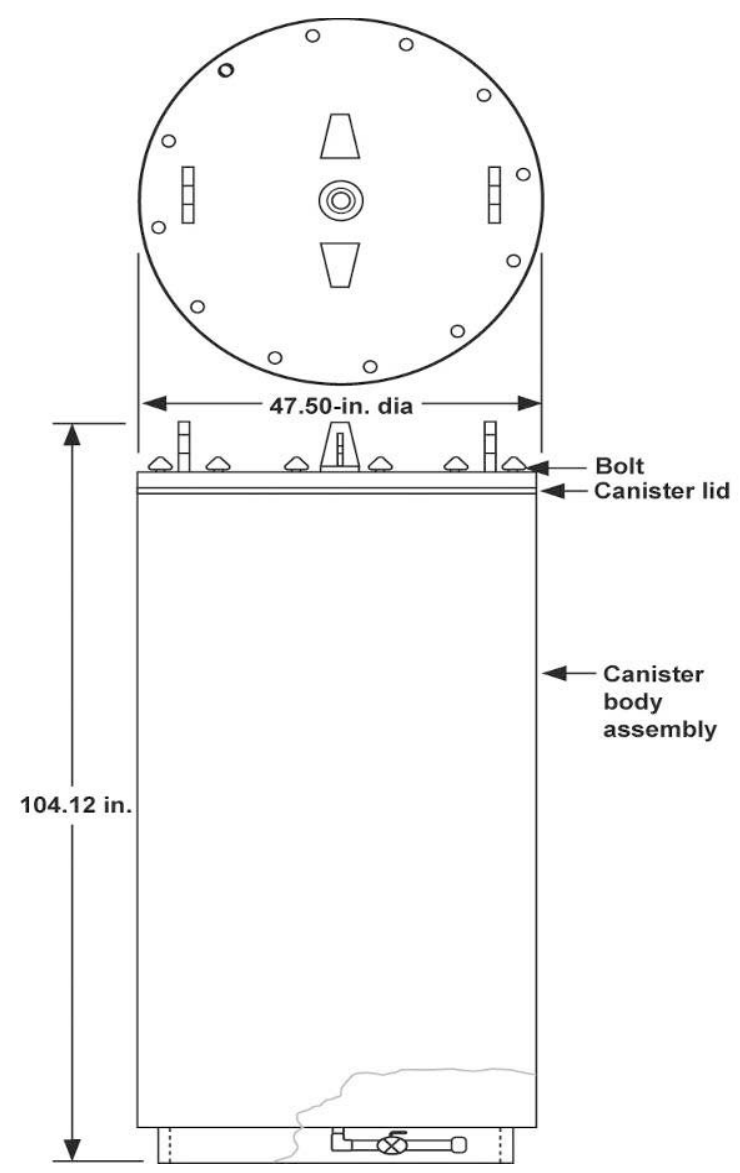

Figure 2-3. Example waste container used inside the 55-ton scrap cask.

- CVAS - The CVAS currently located at RWMC is anticipated to be transferred to the new disposal facility. This system is currently owned by NRF. The CVAS may be modified for use with the new vaults or may be replaced with a similar shielding system. All supporting equipment and components, such as the lifting rigging and control trailer, also will be made available for use.

- Staging and storage area-Staging and storage pads will be provided within the facility for operating equipment. These pads are anticipated to be constructed using pit run gravel with a crushed gravel top surface. Areas will be provided for storage of the crane; the CVAS components, including the working platform; the bearing pad; the shield plugs; and the electrical control trailer.

- Administrative and other supporting infrastructure - Additional support and administrative structures and services are included in the conceptual design, which include the following:

- Administration building

- Electrical distribution

- Maintenance enclosure

- Temporary cask holding area

- Access roads

- Firewater supply. 
- Engineered Cover-Two types of cover will be used at RH LLW disposal project, interim and final cover. Each is described below and depicted in Figure 2-4.

- Interim Cover. An approximate 2-ft-thick interim cover would be placed over the facility as the vaults are filled. The interim cover would increase vault stability and would provide additional protection against water infiltration and water contact with the stainless steel liners.

- Final cover. A final engineered cover would be placed over the facility at the end of operations. The primary purposes of the engineered cover would be to (1) reduce infiltration into the disposal facility after facility closure, thus reducing contaminant transport, and (2) provide a physical barrier against intrusion. The cover would be configured to divert surface water away from the vaults and extend beyond the boundary of the facility. The cover dimensions, layer thicknesses, and other specifications would be determined prior to facility closure and would be based on the final size and configuration of the facility.

Additional details of these listed facility components may be found in the previously referenced CDR, TFR-483, and SPC-1437.

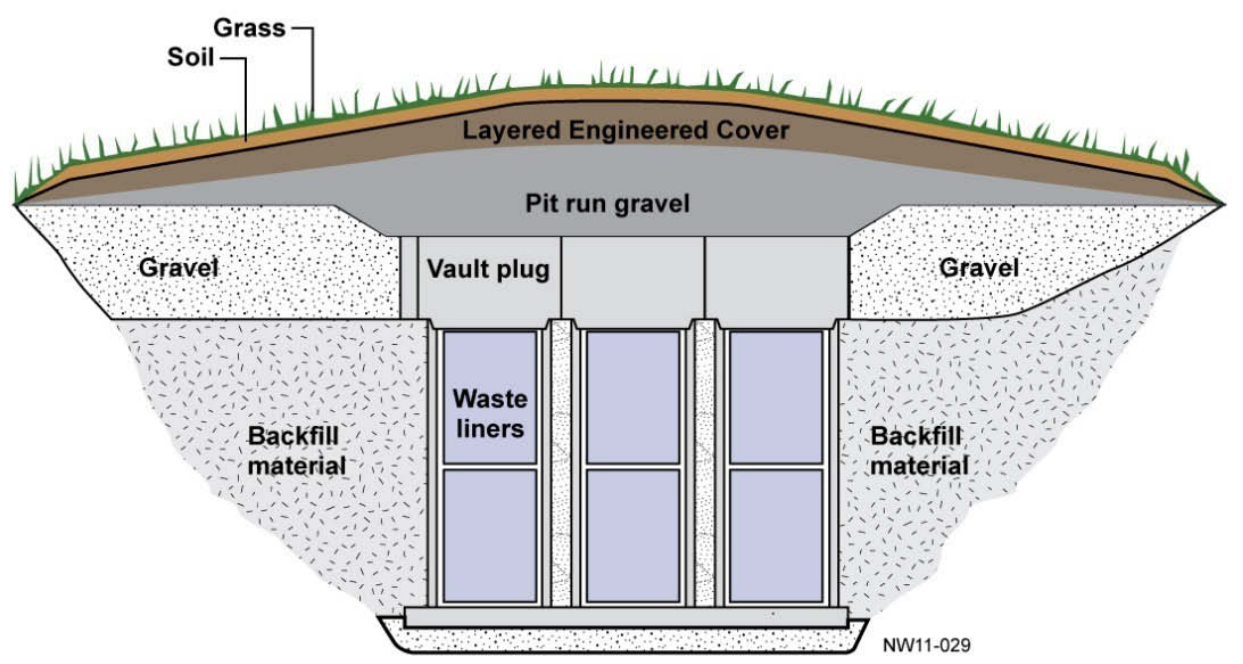

Figure 2-4. RH LLW disposal project engineered cover.

\subsection{Process Description}

This section describes the overall process used for disposal of RH LLW in concrete vaults at the INL. Figure 2-5 shows the general process that is currently being used for NRF RH LLW disposal in the vaults at RWMC. It is assumed that all future waste received from each of the INL generating facilities will be received and disposed of using this same, or similar, sequence of activities. This process is the basis for development of the technical and functional requirements, conceptual design report, and hazard and accident analysis for the proposed disposal project. 
INL/EXT-10-19054

Revision 0
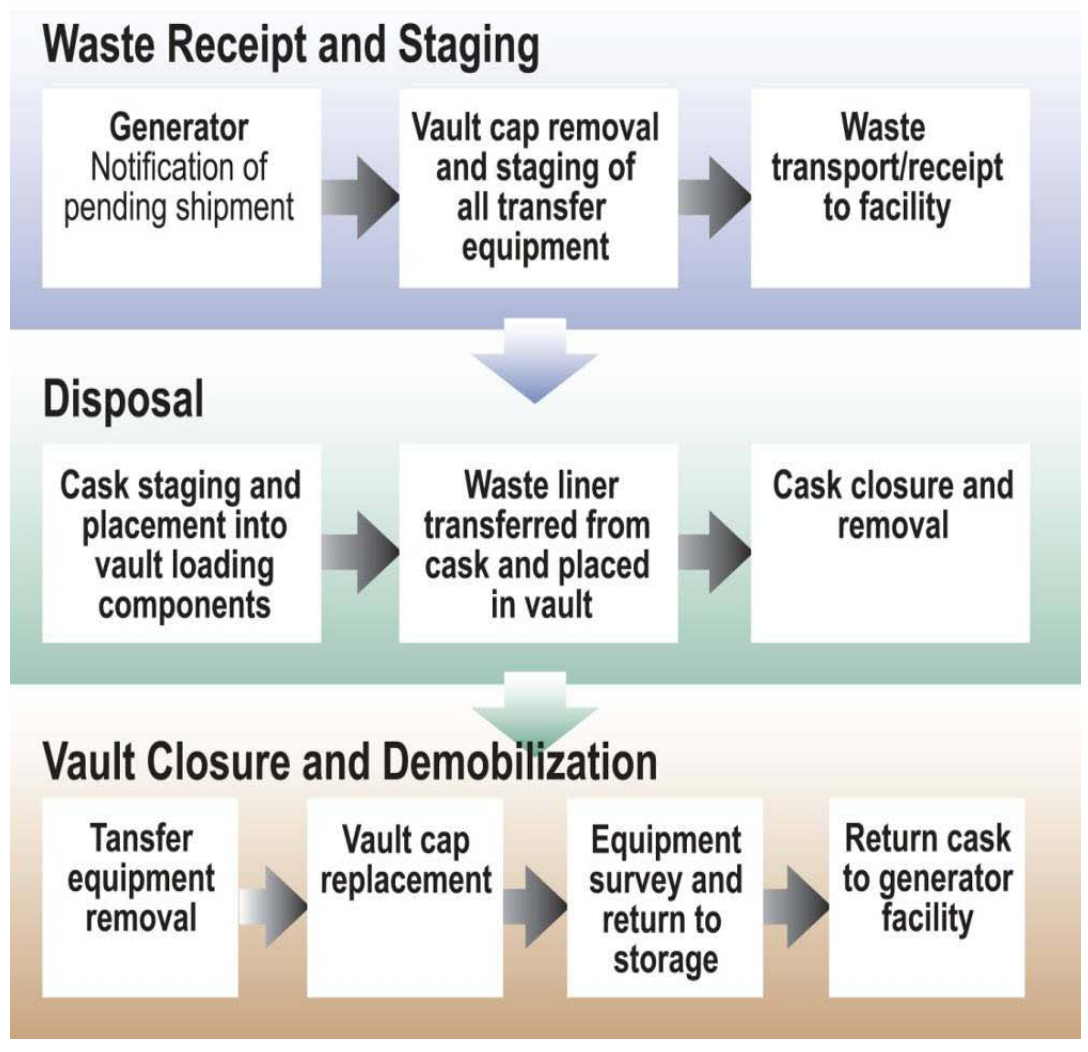

Figure 2-5. RH LLW disposal project process flow diagram.

RH LLW destined for disposal will be packaged into shielded transportation packages with waste containers. The waste containers will normally consist of cylindrical containers designed specifically for the transportation package systems used. It is assumed that RH LLW will be transported from NRF to the proposed disposal facility utilizing the same 55-ton scrap cask that is used at RWMC (see Figure 2-6) or within the new waste cask. Operations involving this cask will be substantially the same as those used at RWMC. The operational system associated with the transportation packages and transfer systems used by other INL generators will be determined once specific waste container designs and transportation package systems are identified. 
INL/EXT-10-19054

Revision 0
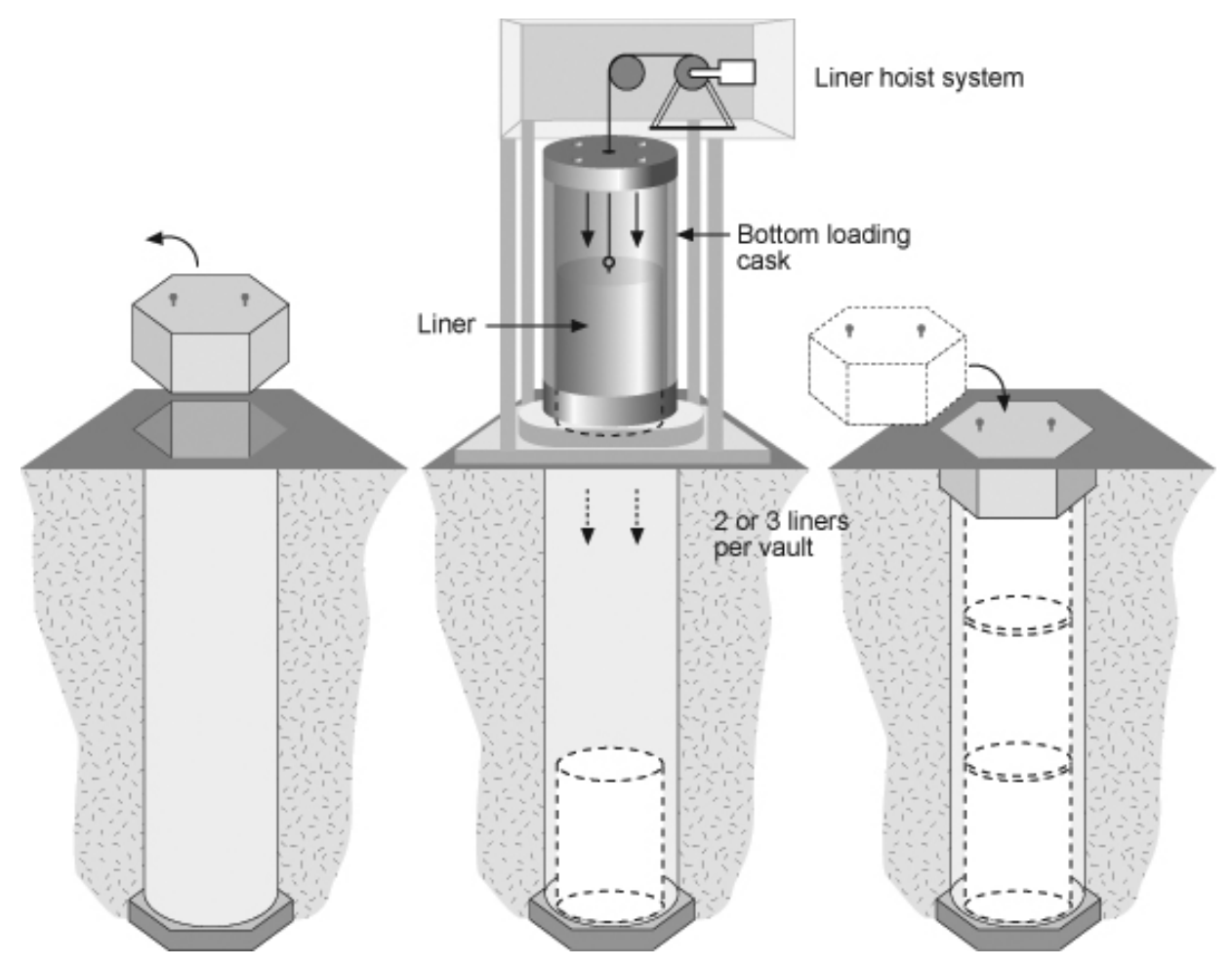

Figure 2-6. Waste container placement method at RWMC.

Only one waste container is anticipated to be transported at any one time. No safety and health monitoring or surveillance, other than normal radiological surveys, is anticipated to be required as a part of normal operations. There may be additional surveillances required during transport and handling of specific waste containers with $>30,000 \mathrm{R} / \mathrm{hr}$ (neutron and gamma) contact exposure rates $(>60,000 \mathrm{R} / \mathrm{hr}$ for NRF waste streams). These requirements will be identified as part of the hazard and accident analysis process.

The current NRF waste container placement process consists of the following steps:

1. Once waste is transported to the site, a 140-ton capacity mobile crane is used to remove the top shield plug on the vault and to position the CVAS on top of the open vault.

2. The 55-ton scrap cask (see Figure 2-7) is removed from the transporter and placed on the CVAS using the crane.

3. A work platform is placed on top of the cask using the crane followed by the remote-operated hoisting system, which is moved from a transport to the top of the cask by the crane and secured in place along with the work platform.

4. Using the remote-operated hoisting system, the waste container is unloaded from the bottom of the cask and lowered into the disposal vault.

5. The cask is closed and the hoisting system, work platform, 55-ton scrap cask, CVAS or equivalent shielding system, and all associated equipment is removed from the top of the vault. 
6. The vault shield plug is replaced.

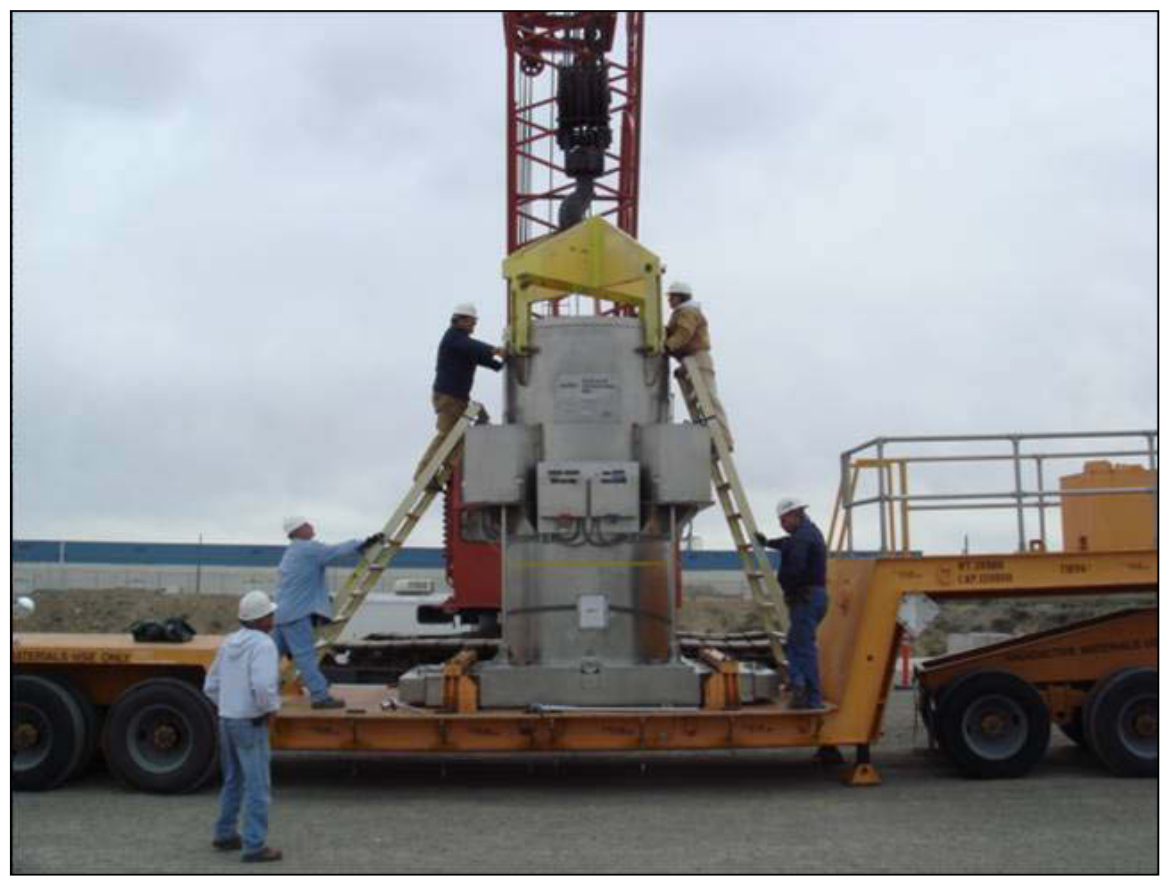

Figure 2-7. 55-ton scrap cask used for transporting waste to a disposal facility.

The specific operational systems and placement procedures to be used in association with transportation package systems for disposal of the RH LLW at the proposed facility will be determined once the generating facilities identify their specific waste container configurations. It is assumed that the following general operational sequence would be used for placement of the waste containers into the associated disposal vaults:

1. Once waste is transported to the site, a crane will be used to remove the top shield plug on the vault and prepare the vault opening for waste container placement using the CVAS and temporary shielding if required.

2. Using the crane, the waste container will be removed from the cask using a shield bell or other shielding equipment and be positioned over the disposal vault, or the cask will be placed on the CVAS.

3. The waste container will be lowered into the disposal vault.

4. The waste container handling and shielding equipment will be removed and the vault shield plug replaced.

\subsection{Summary of Safety-Class and Safety-Significant Structures, Systems, and Components}

Safety-class SSCs are hazard controls for which credit is taken, either preventive or mitigative, to meet the EGs for the off-site public. Based on the results in this PSDR, EGs for the public are not exceeded for unmitigated releases. Therefore, no safety-class SSCs are identified for this facility. 
Safety-significant SSCs are hazard controls for which credit is taken to prevent or mitigate postulated anticipated or unlikely accidents that could result in consequences to collocated or facility workers exceeding EGs. Based on the results discussed in Chapter 3, it is concluded that the potential exists for an accident that could result in direct radiation exposure exceeding these guidelines to the facility worker. The high-density concrete vault shield plugs are identified as a component that would protect the facility worker from these consequences after the waste containers are placed in the vaults. Any shielding required for waste container transfer systems (e.g., CVAS) and systems for top-unloading transportation packages are identified as components that would protect the facility worker from these consequences during placement of the waste containers in the vaults. Finally, the transportation packages shielding is required to protect the facility worker from these consequences during transport and handling of waste containers. The vault shield plugs, shielding required for waste container transfer systems, and shielding required for transportation packages may, therefore be designated as safety-significant SSCs for design and facility planning purposes. As the facility design matures, further analyses will be performed evaluating the direct radiation exposure to the facility worker from specific material being transferred and stored.

\subsection{Utility Distribution Systems}

RH LLW disposal project utility distribution systems are anticipated to include the following:

- Electrical power infrastructure

- $\quad$ Fixed communications system

- Potable water system

- Sanitary sewer system

- $\quad$ Fire detection/protection system

The primary utility needed to operate the new facility is anticipated be electrical power. At the present time, a portable generator is used to power all unloading and waste placement operations at RWMC. Operations at the new facility will use power provided by electrical pedestals that will be located near the disposal vaults. In addition, power will be needed for support infrastructure that is currently provided by RWMC facilities. Other power needs include the administrative building, equipment maintenance and staging, and site control and monitoring capabilities. Location near an existing power source is a benefit but not necessarily a requirement for facility siting. Other utilities, such as fire detection and protection, telecommunication, sewer, and water, also are included in the conceptual design. During final design activities, each of the occupied buildings will be designed to incorporate the applicable sustainable building and energy conservation requirements outlined in DOE O 430.2b, "Renewable Energy and Transportation Management."

A fire safety analysis will be performed as part of the final design. Fire detection and suppression systems will be installed based on the results of the fire-safety analysis. Fire protection for the administration and maintenance buildings will adhere to requirements of the Life-Safety Code (NFPA 101). A preliminary fire hazards assessment has been completed (HAD-474, "Remote-Handled Low-Level Waste Disposal Facility Preliminary Fire Hazards Analysis"). The facility will normally be considered as an unoccupied storage facility; however, the expected occupancy of the administrative building, described below in Section 2.8, is five to ten people for up to 16 days per month. 
INL/EXT-10-19054

Revision 0

\subsection{Auxiliary Systems and Support Facilities}

Additional support and administrative structures and services are included in the conceptual design as follows:

- Access roads:

- Vehicle access within facility and around vaults

- Facility road that provides access to/from major road

- Perimeter fencing

- Administration building:

- Office space

- Records storage

- Equipment storage

- Electrical distribution

- Maintenance enclosure:

- Equipment maintenance

- $\quad$ Temporary cask holding area

- Equipment decontamination

- Equipment storage

If the facility is located adjacent to an existing facility, some of the services described in this section could be provided by that facility.

Road access that will allow transport of the loaded cask vehicles must be provided. Figure 2-8 shows the 55-ton cask transport vehicle. A haul route will be identified or designed that will provide for passage of anticipated cask transport loads without damaging any existing infrastructure. The truck's turning radius, maneuverability, unloading positioning, and drive slopes also will be taken into consideration when determining the haul route alignment. A site area allowing for these transportation operations will be sufficient to allow for adequate road access for unloading operations.

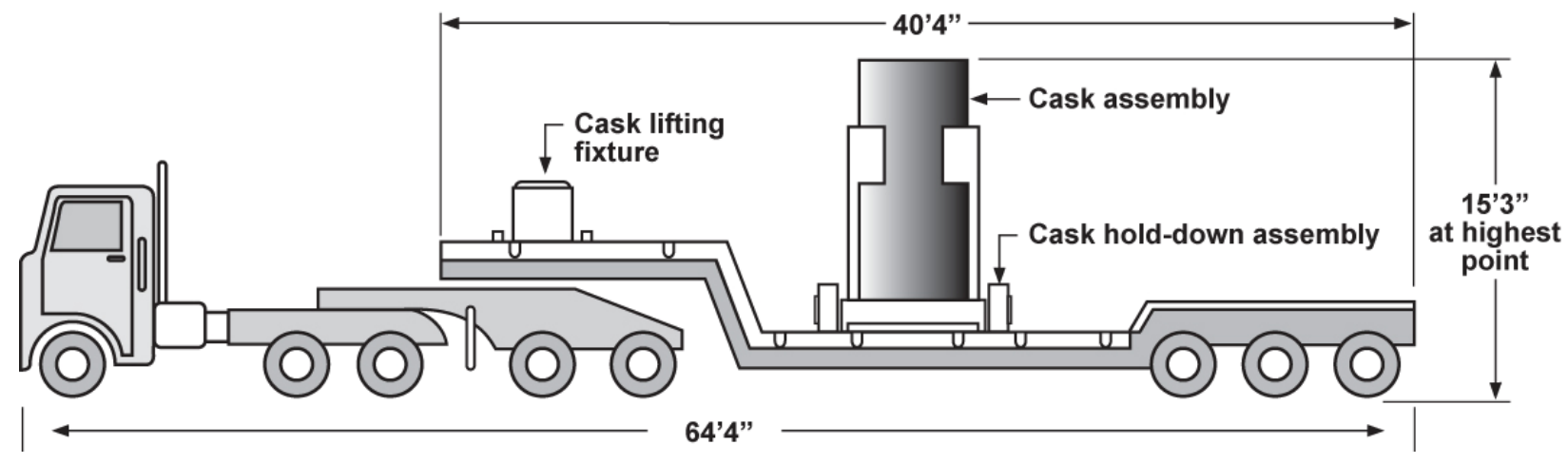

Figure 2-8. An example cask transport vehicle.

Perimeter fencing will be constructed to provide protection from human and animal intrusions and to allow for proper access control. 
An administrative building and a maintenance building are anticipated to support the RH LLW disposal project in addition to the disposal vaults. The administration building will include office space, records/small equipment storage room, and an electrical/storage area. The building is anticipated to be a pre-engineered metal building with concrete foundations and slab on grade. The expected occupancy of the building is 5 to 10 people for up to 16 days per month. The balance of the time it is expected to be unoccupied.

The maintenance building is anticipated to be a high, open bay building that will be used for various maintenance activities and equipment storage related to the CVAS and other required shielding, transportation package, and transport system. Two overhead doors will be provided that allow the transport vehicle to pass through the building if needed. This building is anticipated to be a preengineered metal building with concrete foundations and slab on grade. This building also will provide space for extra shielding components in case they are needed to support special operations.

Both buildings will be designed and inspected in accordance with IBC standards. Both buildings will be designed in accordance with the applicable sustainable building and energy conservation requirements.

\subsection{Design Provisions for Decontamination and Decommissioning}

SAR-400 at Chapter 16, "Provisions for Decontamination and Decommissioning," in SAR-400has been standardized and describes the INL decontamination and decommissioning (D\&D) process, which is applicable to the RH LLW disposal project.

\subsection{References}

DOE-ID, 2009,Mission Need Statement for the Idaho National Laboratory Remote-Handled Low-Level Waste Disposal Project, DOE/ID-11364, Idaho National Laboratory, June 2009.

DOE-ID, 2011, Performance Assessment for the Idaho National Laboratory Remote-Handled LowLevel Waste Disposal Facility (DRAFT), DOE/ID-11421, Idaho National Laboratory.

DOE Order 5400.5, "Radiation Protection of the Public and the Environment," Change 2, U.S. Department of Energy, January 1993.

DOE-STD-1 189-2008, "Integration of Safety into the Design Process," U.S. Department of Energy, March 2008.

DOE-STD-3009-94, "Preparation Guide for U.S. Department of Energy Nonreactor Nuclear Facility Documented Safety Analysis," U.S. Department of Energy, Change Notice 3, March 2006.

INL, 2010a, Remote-handled Low-level Waste Disposal Project Alternatives Analysis, INL/EXT-0917152, Idaho National Laboratory, April 2010.

INL, 2010b,Conceptual Safety Design Report for the Remote-Handled Low-Level Waste Disposal Project, INL/EXT-09-17427, Rev. 1, May 2010.

INL, 2010c, Conceptual Design Report for the Remote-Handled Low-Level Waste Disposal Project, INL/EXT-07-12901, Rev. 2, June 2010.

TFR-483, “Remote-Handled Low-Level Waste Disposal Project,” Rev. 4, January 2012. 
INL/EXT-10-19054

Revision 0

HAD-474, "Remote-Handled Low-Level Waste Disposal Facility Preliminary Fire Hazards Analysis," Draft.

SAR-400, “INL Standardized Safety Analysis Report,” Rev. 1, October, 2008. 
INL/EXT-10-19054

Revision 0

\section{HAZARD ANALYSIS, ACCIDENT ANALYSIS, AND CONTROL SELECTION}

\subsection{Introduction}

This chapter describes the process used to systematically identify and assess hazards, select and analyze accidents, identify and classify controls for significant hazards, and specify the seismic and natural phenomena design criteria for these hazards. This chapter also presents the results of this hazard and accident analysis and control selection process.

\subsection{Hazard Analysis, Accident Analysis, Control Selection, and Classification Methodology}

This section summarizes the methodology used to perform hazard analysis, accident consequence analysis, analysis of DBAs, and control selection as applied during preliminary design.

\subsubsection{Hazard Analysis Methods}

A preliminary hazard analysis (PHA) (INL-2010a) was performed for the hazards that have the potential to result in an uncontrolled release of radioactive or hazardous material and affect the off-site public, collocated workers, facility workers, or the environment. In performing the PHA, the location, hazard, initiating conditions, likelihood, unmitigated consequences, risk, and preventive and mitigative features are considered. The PHA was used in the CSDR and has been updated and incorporated into this PSDR.

The likelihood category reflects a qualitative estimate of whether the hazardous event is anticipated, unlikely, extremely unlikely, or beyond extremely unlikely. The likelihood of a hazardous event is generally the frequency of the initiating event or cause. No credit is taken for controls (i.e., design or administrative) that prevent the event. For an internal event (i.e., events initiated by equipment failure or human error), this generally results in a likelihood category of anticipated (i.e., $10^{-2}$ to $10^{-1}$ per year) since the frequency can depend on the facility design and operation. The likelihood category is based on available data, operating experience, and/or engineering judgment. If there is uncertainty in the likelihood category, the higher likelihood category is conservatively assumed.

The consequence category reflects a qualitative estimate of potential consequences to the off-site public, collocated workers, facility workers, and environment from the hazardous event. A consequence category of high, moderate, low, or negligible is assigned for each receptor and the environment based on the unmitigated quantity of radioactive and/or hazardous material potentially released and the energy source for dispersion. Unmitigated means that a material's quantity, form, location, dispersibility, and interaction with available energy sources are considered, but no credit is taken for safety features (e.g., ventilation system, fire suppression) that could mitigate a hazard. If there is uncertainty in the consequence category, the more severe consequence category is conservatively assumed.

\subsubsection{Accident Consequence Analysis Methods}

Consequence evaluation of the postulated accident scenarios associated with the proposed facility requires a qualitative evaluation of those hazards. This evaluation encompasses internal events, man-made external events, accident initiators at nearby facilities, and NPHs. Sabotage and terrorism are not addressed in the analysis. Internal events occur as a result of facility operations and encompass all operational modes. 
Consequence evaluation involves determining the following for the facility:

1. The material-at-risk (MAR) (i.e., the type and amount of radioactive and hazardous material that is potentially releasable) including the form and location of the material.

2. The direct radiation source term (i.e., quantity of Co-60) that would produce contact direct radiation exposure rates of up to $30,000 \mathrm{R} / \mathrm{hr}$ (neutron and gamma) (up to $60,000 \mathrm{R} / \mathrm{hr}$ for NRF waste streams).

3. Potential energy sources and initiating events that could directly result in injury to workers or affect the inventory of radioactive and hazardous materials.

With respect to MAR, the maximum radionuclide content of any single waste container for the purposes of evaluating inhalation dose consequences is determined for each waste stream (ECAR-1559, "Evaluation of Facility Inventory and Radiological Consequences to Support RH-LLW Disposal Project Safety-Basis and NEPA Documentation") (see Section 3.4.1).

With respect to direct radiation exposure consequences, a source term based on a $30,000 \mathrm{R} / \mathrm{hr}$ (neutron and gamma) contact exposure rate (see Section 3.4.1) is used to determine consequences to the facility worker in the absence of appropriate shielding and/or handling procedures during transfer operations and vault storage. For NRF waste streams, up to $60,000 \mathrm{R} / \mathrm{hr}$ contact exposure rates are possible; therefore, in the case of NRF wastes streams, the source term is based on a $60,000 \mathrm{R} / \mathrm{hr}$ (neutron and gamma) contact exposure rate.

It should be noted that some of the waste streams may contain combustible materials such as plastics and other combustible radioactive wastes. Waste containers with resins may also be subject to radiolytic water decomposition (i.e., hydrogen production) and/or corrosion-induced waste container failure during long-term storage. All of these specific materials are considered individually during the development of the PHA including likelihood and consequence evaluation.

Hazardous material inventories for construction and operation of the proposed RH LLW disposal project are very low in comparison to other INL operations and commensurate with existing RWMC RH LLW operations. No chemicals found in the Occupational Safety and Health Act substance specific standards have been identified that would create a potential for exposure triggering medical surveillance during construction or operation. Additionally, no highly hazardous chemicals listed in 29 CFR 1910.119, "Process Safety Management of Highly Hazardous Chemicals," (Appendix A, List of Highly Hazardous Chemicals, or Toxics and Reactives) will be generated, used, or disposed of at this facility.

\subsubsection{Method for Analysis of Design-Basis Accidents}

The airborne source term (ST) and consequences for each DBA are estimated by considering the MAR (Curies), damage ratio (DR), airborne release fraction (ARF), respirable fraction (RF), and leak path factor (LPF), as applicable. These factors and the values of the factors are explained and presented in DOE-HDBK-3010-2004, "Airborne Release Fraction/Rates and Respirable Fractions for Nonreactor Nuclear Facilities." The five-factor formula (DOE-HDBK-3010-94) for estimating the ST is:

$\mathrm{ST}=\mathrm{MAR} \times \mathrm{DR} \times \mathrm{ARF} \times \mathrm{RF} \times \mathrm{LPF}$

The inhalation dose consequences are estimated from:

Dose $(\mathrm{rem}) \quad=\mathrm{ST} \times \chi / \mathrm{Q} \times \mathrm{BR} \times \mathrm{DCF} \times \mathrm{DC}$ 
Breathing rate (BR) is the assumed breathing rate described in DOE O $440.1 \mathrm{~B}$ and is 3.33E-4 m³ $/ \mathrm{sec}$.ICRP-68, "Dose Coefficients for Intakes of Radionuclides by Workers," dose conversion factor (DCF) values were utilized in the CED calculation for facility and collocated workers, and ICRP-72, "Age-dependent Doses from Intakes of Radionuclides," DCF values were utilized in the calculation of the CED for the public. In both cases, the DCF for the lung absorption type that would result in the highest dose was selected.

Deposition coefficients (DCs) and $\chi / \mathrm{Q}$ values for downwind distances were obtained from Radiological Safety Analysis Computer (RSAC) modeling for instantaneous releases using 95 percentile meteorological conditions specific to the INL. The meteorological model in RSAC 7.2 calculates Gaussian plume diffusion using Pasquill-Gifford, Hilsmeier-Gifford, or Markee sigmas. The Markee model is used in this analysis for collocated workers and the public. The input parameters and outputs for determining DCs and $\chi / \mathrm{Q}$ values are indicated in the RSAC output report in ECAR-1559. The $\chi / \mathrm{Q}$ values are $4.08 \mathrm{E}-03 \mathrm{~s} / \mathrm{m}^{3}$ at $100 \mathrm{~m}$ and $5.32 \mathrm{E}-05 \mathrm{~s} / \mathrm{m}^{3}$ at $4,000 \mathrm{~m}$, respectively. DCs are 0.978 at $100 \mathrm{~m}$ and 0.919 at $4,000 \mathrm{~m}$. It should be noted that the site-specific $\chi / \mathrm{Q}$ value at $100 \mathrm{~m}$ is higher than the value of $3.5 \mathrm{E}-3 \mathrm{~s} / \mathrm{m}^{3}$ specified in DOE-STD-1189-2008, and is therefore conservative. It should also be noted that the $\chi / \mathrm{Q}$ value for the off-site public is evaluated at $4,000 \mathrm{~m}$ which is the distance to the location of the nearest public receptor based on the selected site discussed in Section 1.2.

Facility worker inhalation dose is estimated based on dispersion of airborne radioactive material into a volume $10 \times 10 \times 10 \mathrm{~m}$. The resulting facility worker dose is expressed as:

$$
\mathrm{CED}=\mathrm{ST} / 1,000 \mathrm{~m}^{3} \times 60 \mathrm{sec} / \mathrm{min} \times \mathrm{BR} \times \mathrm{DCF}
$$

The CED for facility workers is therefore expressed in units of rem/min. This allows a facility worker inhalation dose to be estimated based on worker stay time, as workers are trained to evacuate the area in the event of a radioactive material release event. Once the workers have evacuated the area, the inhalation doses are significantly lower.

Direct radiation exposure rates were determined using MicroShield as described in ECAR-1559. For modeling purposes, the containers are represented as uniformly-distributed cylindrical sources configured both horizontally and vertically in order to determine the maximum exposure rates. Exposure rates were analyzed at dose points $10 \mathrm{~m}$ (facility worker), $100 \mathrm{~m}$ (collocated worker), and 4,000 m (public) from the bare source neglecting the potential shielding provided by the waste container. As described previously, direct radiation exposure source terms were derived for each type of waste container and each type of material disposed in those containers that would result in a $30,000 \mathrm{R} / \mathrm{hr}$ (neutron and gamma) contact exposure rate $(60,000 \mathrm{R} / \mathrm{hr}$ contact exposure rate for NRF waste streams). The source terms were represented with the radius and height of each waste container and the source density was estimated based the mass of material to be loaded in the containers and the volume of the specific container. The material type was represented in MicroShield as iron for metals and wastes and as carbon for resins with the derived density. Specific input parameters are documented in ECAR-1559.

\subsubsection{Control Selection and Classification Methods}

Table 3-1 defines the INL radiological risk EGs used for deriving the need for safety-class or safety-significant SSCs for facility and collocated workers and for the off-site public. These EGs are documented in NS-18104, "INL Guide to Safety Analysis Methodology," as supplemented in OS-QSD-050121, CCN 202983, "Nuclear Safety Rule Supplementation Information.” Determining whether the consequences from a postulated event exceed the EGs for the corresponding likelihood for that event determines if safety SSCs or safety analysis commitments are required as a control for that event. For each of the identified DBAs, the consequence and likelihood were identified and compared to 
the EGs. For any DBA with the potential to exceed the off-site public consequences identified in Table 3-1, safety-class SSCs are identified. For any DBA with the potential to exceed collocated or facility worker consequences identified in Table 3-1, safety-significant SSCs are identified.

Table 3-1.INL radiological risk evaluation guidelines.

\begin{tabular}{|l|c|c|}
\hline \multicolumn{1}{|c|}{ Event Likelihood } & $\begin{array}{c}\text { Collocated and Facility Worker } \\
\text { Consequences }\end{array}$ & Off-Site Public Consequences \\
\hline Anticipated $\left(10^{-2}\right.$ to $\left.10^{-1} / \mathrm{yr}\right)$ & 5.0 rem (low) & 0.5 rem (low) \\
\hline Unlikely $\left(10^{-4}\right.$ to $\left.10^{-2} / \mathrm{yr}\right)$ & $25 \mathrm{rem}$ (moderate) & 5 rem (moderate) \\
\hline Extremely unlikely $\left(10^{-6}\right.$ to $\left.10^{-4} / \mathrm{yr}\right)$ & 100 rem (high) & 25 rem (high) \\
\hline
\end{tabular}

\subsection{Hazard Analysis Results}

The results of the PHA are shown in Table 3-2 and include identification of hazards and initiators that should be considered as the design progresses and the safety-basis documentation is being prepared. Based on the results of the PHA, several postulated events are selected as representative, bounding, and/or unique accidents. These accidents, defined as DBAs and derived from the PHA, include:

- Vehicle fuel fire (bounds all fire and explosion events)

- Container drop accident (bounds all radioactive material release events)

- Direct radiation exposure during waste container handling (representative for all direct radiation exposure events)

- Severe seismic event (representative for all NPH events)

- External events (consequences bounded by other events) 


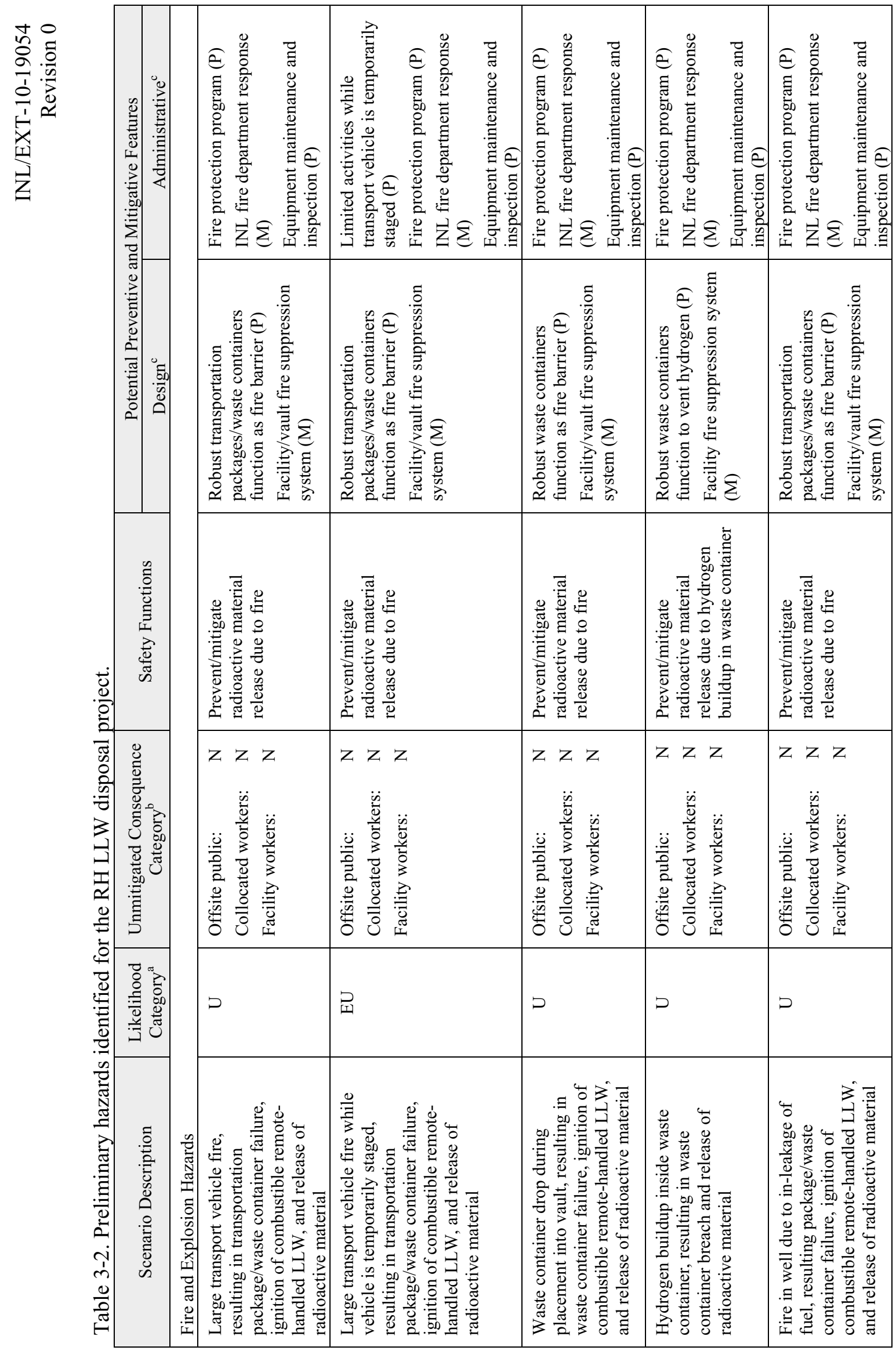




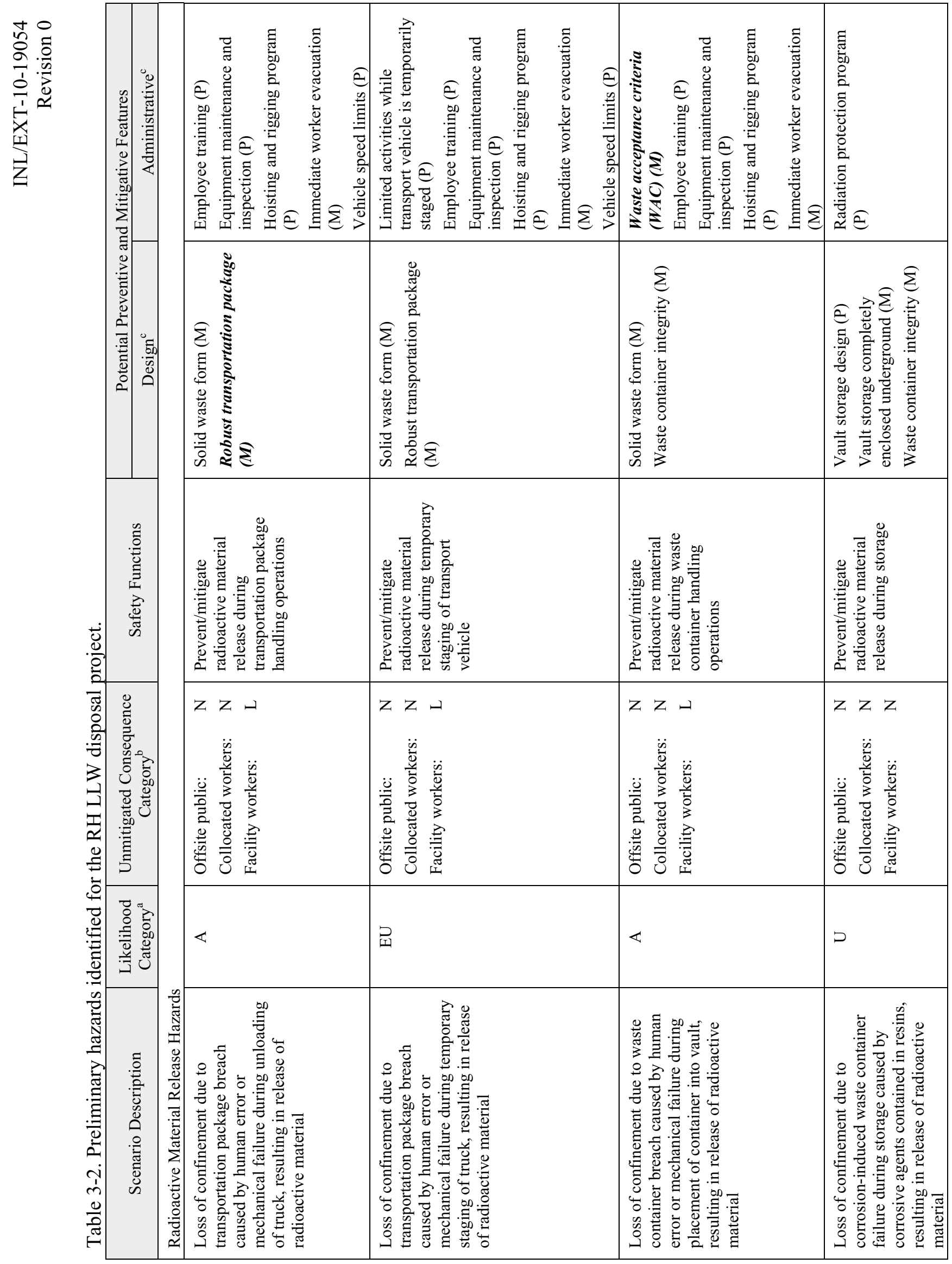

m 


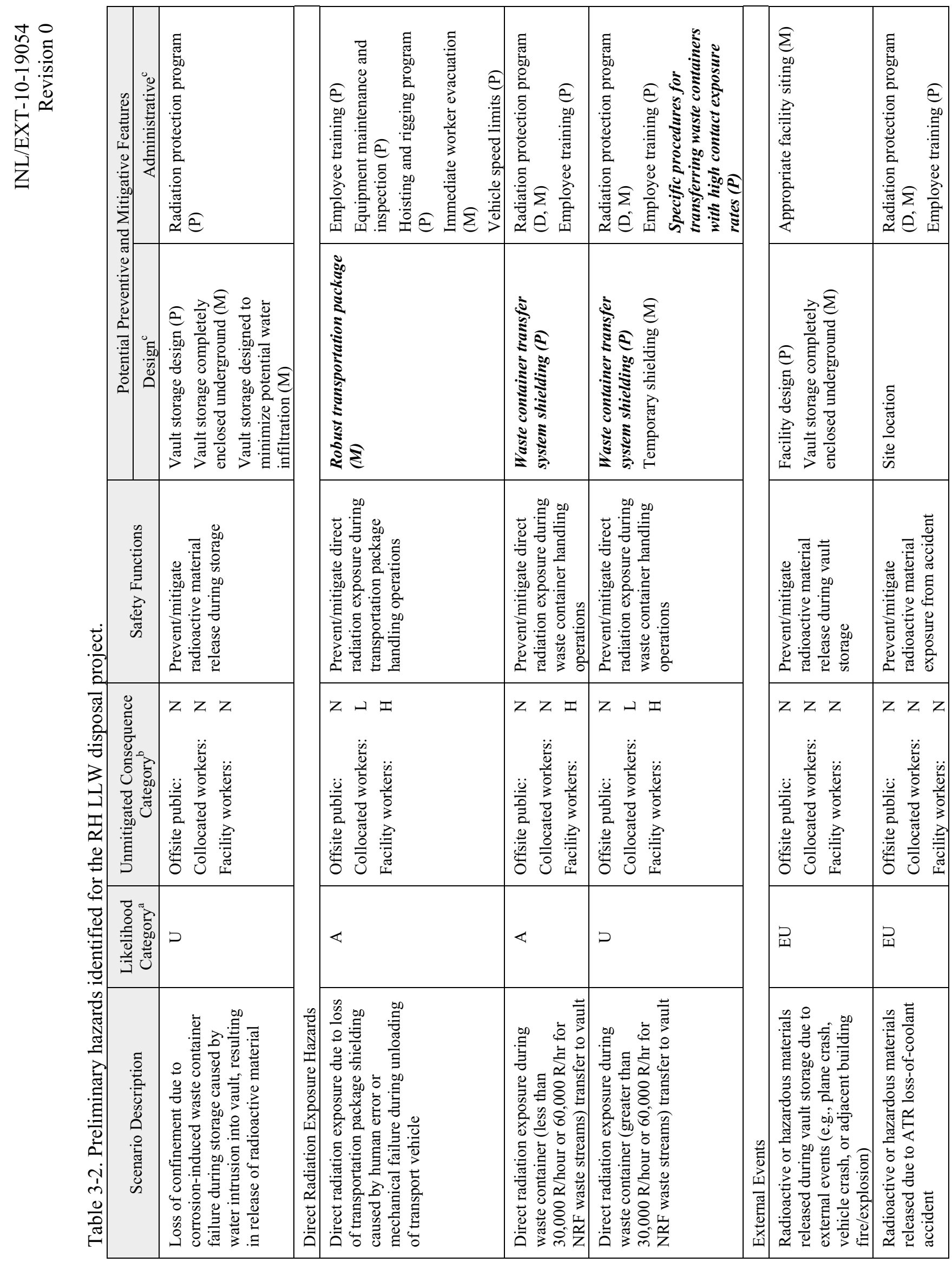

ñ 


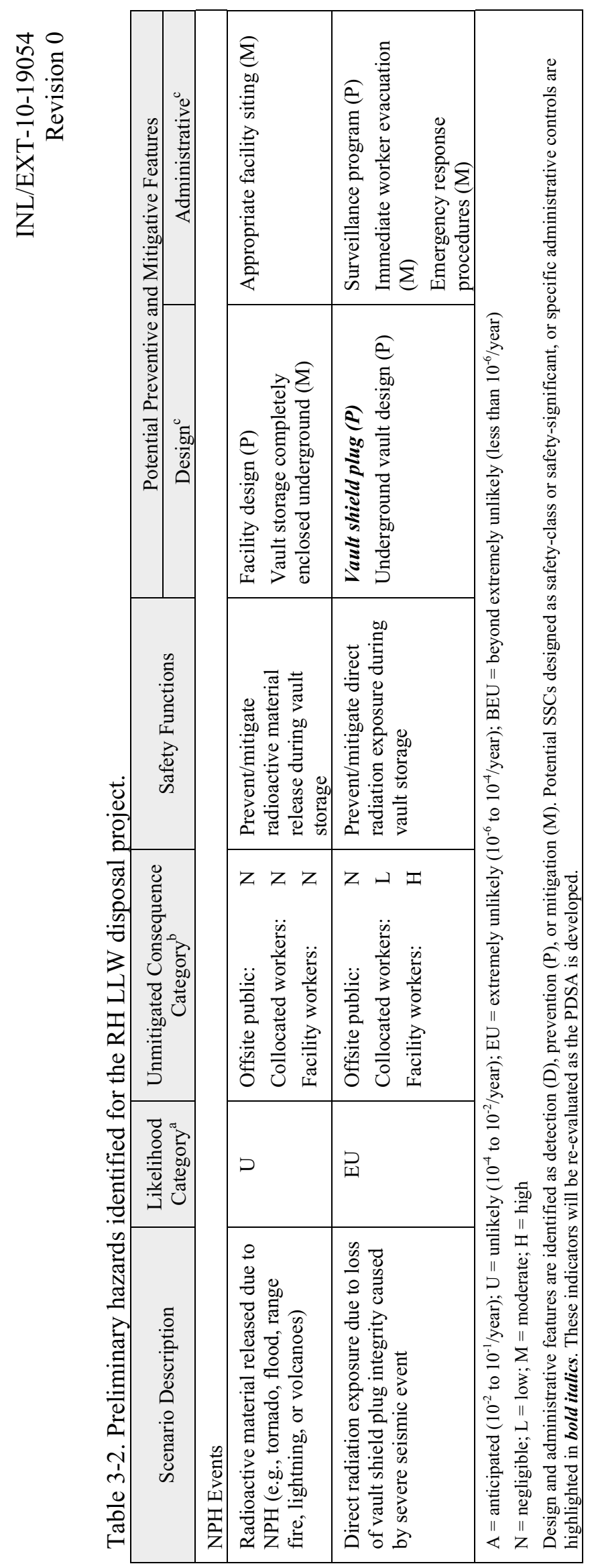


INL/EXT-10-19054

Revision 0

\subsection{Facility Hazard Classification}

\subsubsection{Hazardous Material Inventories}

RH LLW is considered as any waste container with a contact exposure rate (including neutron and beta radiation) $>200 \mathrm{mrem} / \mathrm{hr}$. If internally or externally shielded, the $>200 \mathrm{mrem} / \mathrm{hr}$ threshold applies to the expected contact exposure rate without shielding. Contact exposure rates on containers placed at the RH LLW disposal project may be as high as $30,000 \mathrm{R} / \mathrm{hr}$ (neutron and gamma) (60,000 R/hr for NRF waste streams). Should shielded containers be designed for placement in the proposed RH LLW disposal project, such containers will not have any Resource Conservation and Recovery Act (RCRA) regulated metals that are unconfined and/or exposed to the environment.

The waste containers associated with the various RH LLW streams are anticipated to contain irradiated hardware, highly radioactive process materials, or nuclear reactor system resins. Though some variability in form is expected, most of the radioactive material will be in the form of irradiated solids or ion exchange resins with contaminants attached to the resin particle surface. Radioactive liquids are specifically prohibited from these waste streams, and combustible materials in the waste streams are known to exist only in limited quantities.

The waste streams that will be accepted for storage at the RH LLW disposal project must meet the requirements for LLW as specified in DOE Manual 435.1-1, "Radioactive Waste Management Manual." These requirements specify that the material must contain $<100 \mathrm{nCi} / \mathrm{g}$ transuranic (TRU) radionuclides. The bounding TRU content for any container, evaluated in ECAR-1559, is shown in Table 3-3.In addition, radionuclide content for Co-60 (representative of radionuclides that contribute to direct radiation exposure) and fissile material content are also shown in Table 3-3.These values are based on bounding radionuclide concentrations estimated for each waste stream, and in most cases include significant conservative margins. 
INL/EXT-10-19054

Revision 0

Table 3-3.Bounding radionuclide content for RH LLW disposal project containers.

\begin{tabular}{|l|c|c|c|c|}
\hline \multirow{2}{*}{ Waste Stream } & Container & $\begin{array}{c}\text { TRU content, } \\
\text { nCi/g }\end{array}$ & $\begin{array}{c}\text { Co-60 content, } \\
\text { Ci }\end{array}$ & $\begin{array}{c}\text { Material } \\
\text { Content, } g\end{array}$ \\
\hline \multirow{2}{*}{ NRF activated metals } & 55 -ton cask liner & 5.4 & 2500 & 0.06 \\
\cline { 2 - 5 } NRF resins & New concept container & 5.4 & 7000 & 0.15 \\
\hline \multirow{2}{*}{ ATR activated metals } & 55-ton cask liner & 7.4 & 159 & 0.17 \\
\hline \multirow{2}{*}{ ATR resins } & $\begin{array}{c}\text { Single-Contained HFEF-5 } \\
\text { cask liner }\end{array}$ & 0 & 443 & 0.48 \\
\hline MFC activated metals & $\begin{array}{c}\text { NuPac } 14 / 210 \text { L Resin } \\
\text { Liner }\end{array}$ & 5.0 & 44 & 0 \\
\hline MFC legacy waste (RSWF) & $\begin{array}{c}\text { HFEF-5 cask liner } \\
\text { "24-over-16" cask liner in } \\
\text { modified FTC cask }\end{array}$ & 0.002 & 2690 & 1.2 \\
\hline MFC legacy waste (SN cans) & HFEF-5 cask liner & 18.3 & 337 & 60.001 \\
\hline MFC future (HFEF) & HFEF-5 cask liner & 26 & $<0.001$ & 0.5 \\
\hline MFC future (FCF) & HFEF-5 cask liner & 20 & $<0.001$ & 4.5 \\
\hline
\end{tabular}

Waste containers will be transported within the INL boundary to the RH LLW disposal project and therefore will be compliant with the transportation limits specified in 40 CFR 173.424(h) for "Excepted packages for radioactive instruments and articles" as described in TEV-1119, "Assessment of Potential for Inadvertent Nuclear Criticality in the RH LLW Disposal Project." This requirement specifies a $15 \mathrm{~g}$ U-235 equivalent transportation limit. A mass limit of $15 \mathrm{~g} \mathrm{U}-235$ equivalent would preclude potential criticality. As the design-build process proceeds, the commitment for further criticality safety assessments will be evaluated.

It should be noted that WAC will be developed for the RH LLW disposal project to ensure that waste streams accepted for disposal will not exceed maximum established radionuclide content for each waste stream. These WAC will further ensure that waste streams do not have the potential to exceed EGs due to inhalation dose consequences or direct radiation exposure. In particular, the WAC will identify those containers that may require waste container transfer system shielding and/or specific procedures for transferring waste containers with high contact exposure rates.

\subsubsection{Comparison of Inventories to Threshold Quantities}

Based on an assessment of the anticipated RH LLW streams and a comparison with DOE-STD-1027-92 TQs, the RH LLW disposal project would have an initial hazard categorization of a HC-2 nuclear facility based on the entire facility inventory. This preliminary categorization is documented in the SDS (INL 2010b). The total RH LLW disposal project radioactive material inventory anticipated to be present in the facility at a given time will exceed the HC-2 TQ values for several radionuclides. However, DOE-STD-1027-92 supplemental guidance provides for facility categorization modification in the final hazard categorization process considering 1) alternative release fractions, or 2) change in material subject to an accident due to facility features that preclude bringing material together or causing harmful interaction from a common severe phenomenon (facility segmentation). For the RH LLW disposal project, alternative release fractions are not considered because the differences in 
waste stream characteristics would require alternative release fractions for each waste stream, e. g., the release fractions for activated metals would be lower than those for resins or other non-metallic waste forms.

The maximum individual vault inventory is based on specifications in the CDR (INL, 2010c) that no more than two waste canisters will be placed in any single vault. Maximum radionuclide distributions and concentrations for each of the waste streams are provided in separate references and are evaluated in ECAR-1559 to determine the maximum radionuclide inventory and distribution for each container. On this basis, the maximum ratio of the radionuclide content in any single vault to the HC-2 TQs is shown in Table 3-4.

Table 3-4. Sum of ratios of individual vault inventory to HC-2 TQs.

\begin{tabular}{|l|c|c|c|c|}
\hline \multicolumn{1}{|c|}{ Waste Stream } & Container Designation & $\begin{array}{c}\text { Sum of Ratios to } \\
\text { HC-2 TQs (single } \\
\text { container) }\end{array}$ & $\begin{array}{c}\text { Number of } \\
\text { Containers per } \\
\text { vault* }\end{array}$ & $\begin{array}{c}\text { Sum of Ratios } \\
\text { to HC-2 TQs } \\
\text { (single vault) }\end{array}$ \\
\hline NRF activated metals & 55-ton cask liner & 0.021 & 2 & 0.041 \\
\hline NRF activated metals & New concept container & 0.058 & 1 & 0.058 \\
\hline \multirow{2}{*}{ NRF resins } & 55-ton cask liner & 0.001 & 2 & 0.002 \\
\cline { 2 - 5 } & New concept container & 0.003 & 1 & 0.003 \\
\hline ATR activated metals & $\begin{array}{c}\text { Single-Contained HFEF-5 } \\
\text { cask liner }\end{array}$ & $<0.01$ & 2 & 0.02 \\
\hline ATR resins & $\begin{array}{c}\text { NuPac 14/210L Resin } \\
\text { Liner }\end{array}$ & $<0.001$ & 2 & 0.002 \\
\hline MFC activated metals & HFEF-5 cask liner & 0.014 & 2 & 0.028 \\
\hline MFC legacy waste (RSWF) & $\begin{array}{c}\text { "24-over-16" cask liner in } \\
\text { modified FTC cask }\end{array}$ & 0.001 & 1 & 0.002 \\
\hline MFC legacy waste (SN cans) & HFEF-5 cask liner & $<0.001$ & 2 & $<0.001$ \\
\hline MFC future (FCF) & HFEF-5 cask liner & 0.003 & 2 & 0.005 \\
\hline MFC future (HFEF) & HFEF-5 cask liner & $<0.001$ & 2 & $<0.001$ \\
\hline * (INL, 2010c). & \multicolumn{2}{|l}{} \\
\hline
\end{tabular}

As shown by the results in Table 3-4, individual vaults can be categorized as HC-3. Individual vaults can be considered separate facility segments per DOE guidance (DOE-STD-1027-92) based on the following:

- Waste containers will be transported and placed into storage vaults individually, i.e., there will be no more than a single waste container present outside of a closed vault at any given time.

- Each vault will be buried in an array with a sand backfill that will completely separate the individual vaults.

- Each vault will be placed on a concrete vault foundation and will have a separate removable concrete plug placed on top of the cylinder to serve as a radiation shield and an environmental barrier. 
INL/EXT-10-19054

Revision 0

- Once the vaults are completely buried, there are no facility operations that can bring the contents of more than a single vault together. Once a vault is filled with no more than two waste containers, the vault shield plug is put in place, thereby isolating the vault from the adjacent vaults comprising the array.

Because the individual vaults at the RH LLW disposal project can be considered individual facility segments, and the maximum hazard categorization for a single vault is no greater than $\mathrm{HC}-3$, the hazard category for the RH LLW disposal project can be HC-3. The decision to pursue the lower hazard category has not been made at this stage of the project, but consideration to categorize the RH LLW disposal project as an HC-3 facility will be documented in the PDSA and final DSA per NS-18101, "INL Safety Analysis Process."

\subsection{Results of Analysis of Accidents}

The unmitigated analyses for the DBAs are summarized in this section. The accidents considered here are used to determine if safety SSCs would be considered at this stage of facility design and are preliminary in nature. Experience in other underground waste disposal facilities indicates that these events typically represent the highest risk in terms of likelihood and consequence. During subsequent safety document development, these accidents will be further evaluated, documented, and peer reviewed.

\subsubsection{Vehicle Fuel Fire}

\subsubsection{Scenario Development}

As addressed in the FHA, the lifting and handling of transportation packages and waste containers requires the use of trucks, tractor/trailer combinations, and a crane. These vehicles introduce the potential for a vehicle fire that is postulated to occur during transport or during transportation package/waste container unloading activities. Such a fire is postulated to initiate from the ignition of diesel fuel from the transport vehicle or crane, which then entirely engulfs the transportation package/waste container being transported or unloaded. This is postulated to result in volatilization of a fraction of the waste material being handled. This accident analysis considers only material that is affected by the thermal stresses from the fire as container boundaries are breached. Material already in storage is not involved in this accident. The likelihood of this accident is judged as unlikely based on the limited number of miles that transport vehicles would travel on the RH LLW disposal project site, minimal ignition sources, and robust transportation package/waste container design that would prevent a fire from spreading to, and engulfing, the entire contents.

During the fire scenario, shielding provided by the transportation package or transfer unit is assumed maintained in place. Therefore, dose to the facility worker, collocated worker, and public in this case is assumed to be only from intake of radiological material made airborne in the fire. Direct radiation exposure consequences and associated controls due to the handling accidents are addressed in Section 3.5.3.

\subsubsection{Analysis of Radiological Source Term and/or Chemical Exposure}

The MAR for release of radioactive material in this scenario is limited to the contents of a single waste container. An unmitigated analysis is performed for which the hazardous material's quantity, form, location, dispersibility, and interaction with available energy are considered, but no credit is taken for safety features that could mitigate the consequences of a hazard. The MAR is defined for each waste stream in ECAR-1559. Values used to calculate a ST for uptake in this accident are waste-stream specific as shown in Table 3-5. 
Table 3-5. Release factors for RH LLW disposal project fire scenarios.

\begin{tabular}{|c|c|c|c|l|}
\hline Waste Stream & DR & ARF & RF & \multicolumn{1}{|c|}{ Applicable MAR } \\
\hline Activated metals & 0.1 & $6 \mathrm{E}-3$ & 0.01 & $\begin{array}{l}\text { Contaminated, noncombustible solids exposed to thermal stress } \\
\text { [bounded by suspension of surface contamination exposed to thermal } \\
\text { stress (DOE-HDBK-3010-94, p, 5-5); applicable to activated metals } \\
\text { that are considered noncombustible] }\end{array}$ \\
\hline Resins & 0.1 & $1 \mathrm{E}-2$ & 1.0 & $\begin{array}{l}\text { Contaminated, combustible plastics exposed to thermal stress } \\
\text { [bounded by uncontained cellulosic mixed waste exposed to thermal } \\
\text { stress (DOE-HDBK-3010-94, p, 5-2)] }\end{array}$ \\
\hline $\begin{array}{c}\text { Nonmetallic } \\
\text { wastes }\end{array}$ & 0.1 & $5 \mathrm{E}-4$ & 1.0 & $\begin{array}{l}\text { Contaminated, combustible solids exposed to thermal stress } \\
\text { [bounded by packaged mixed waste exposed to thermal stress (DOE- } \\
\text { HDBK-3010-94, p. 5-1)] }\end{array}$ \\
\hline
\end{tabular}

The DR of 0.1 is based on engineering judgment of the amount of material impacted from an engulfing fire where the source material contains combustibles and originates within multiple layers of protection (i.e., stainless steel liner and cask).

LPF of 1.0 is a standard assumption for DOE facilities and activities and is appropriate for an outdoor event such as what is being evaluated.

The ST and inhalation dose consequences are evaluated as discussed in Section 3.2.3; results are shown in Table 3-6.Although a fire may be a longer duration event than other radioactive material releases events, airborne dispersion is evaluated as discussed in Section 3.2.3 for an instantaneous release. This is conservative because the airborne dispersion parameters for longer-duration events or events such as fires with significant plume rise are lower than those for instantaneous releases (INL 2009).

Table 3-6. Inhalation dose consequences for RH LLW disposal project fire scenarios.

\begin{tabular}{|c|c|c|c|c|}
\hline \multirow{2}{*}{ Waste Stream } & Container & $\begin{array}{c}\text { Facility Worker, } \\
\text { rem/min }\end{array}$ & $\begin{array}{c}\text { Collocated } \\
\text { Worker, rem }\end{array}$ & Public, rem \\
\hline \multirow{2}{*}{ NRF metals } & 55 -ton cask liner & $2.9 \mathrm{E}-02$ & $1.9 \mathrm{E}-03$ & $4.6 \mathrm{E}-05$ \\
\cline { 2 - 5 } & New concept container & $8.1 \mathrm{E}-02$ & $5.4 \mathrm{E}-03$ & $1.3 \mathrm{E}-04$ \\
\hline \multirow{2}{*}{ NRF resins } & 55 -ton cask liner & $2.7 \mathrm{E}-01$ & $1.8 \mathrm{E}-02$ & $4.4 \mathrm{E}-04$ \\
\cline { 2 - 5 } & New concept container & $7.6 \mathrm{E}-01$ & $5.1 \mathrm{E}-02$ & $1.2 \mathrm{E}-03$ \\
\hline \multirow{2}{*}{ ATR activated metals } & $\begin{array}{c}\text { Single-contained HFEF-5 } \\
\text { cask liner }\end{array}$ & $1.6 \mathrm{E}-02$ & $1.0 \mathrm{E}-03$ & $2.3 \mathrm{E}-05$ \\
\hline ATR resins & NuPac $14 / 210 \mathrm{~L}$ resin liner & $1.5 \mathrm{E}-01$ & $1.0 \mathrm{E}-02$ & $2.8 \mathrm{E}-04$ \\
\hline MFC activated metals & HFEF-5 cask liner & $2.0 \mathrm{E}-02$ & $1.4 \mathrm{E}-03$ & $3.0 \mathrm{E}-05$ \\
\hline \multirow{2}{*}{ MFC legacy waste (RSWF) } & $\begin{array}{c}\text { "24-over-16" cask liner in } \\
\text { modified FTC cask }\end{array}$ & $2.3 \mathrm{E}-02$ & $1.6 \mathrm{E}-03$ & $3.5 \mathrm{E}-05$ \\
\hline MFC legacy waste (SN cans) & HFEF-5 cask liner & $3.9 \mathrm{E}-04$ & $2.6 \mathrm{E}-05$ & $7.9 \mathrm{E}-07$ \\
\hline MFC future (FCF) & HFEF-5 cask liner & $1.5 \mathrm{E}-02$ & $1.0 \mathrm{E}-03$ & $2.9 \mathrm{E}-05$ \\
\hline MFC future (HFEF) & HFEF-5 cask liner & $3.9 \mathrm{E}-04$ & $2.6 \mathrm{E}-05$ & $7.9 \mathrm{E}-07$ \\
\hline
\end{tabular}


INL/EXT-10-19054

Revision 0

\subsubsection{Design Requirements}

There are no design requirements for fire detection and suppression systems based on the results of this accident analysis. The FHA (HAD-474) identifies fire water systems, fire detection and alarm systems, and fire department and area Incident Alarm Team requirements that are applicable to this facility based on life safety and property damage concerns. The FHA also recommends that the access pad and roadway around the disposal vaults and facility grounds will need to be connected with a drainage ditch that leads to a catch basin which is located in a remote area away from the vault arrays and support buildings.

\subsubsection{Control Selection and Classification}

Dose consequence EGs for the public and facility/collocated workers are 5 rem and 25 rem, respectively, for unlikely events. As shown in Table 3-6, the dose consequence to the nearest facility worker is $<8$ rem for a 10 minute exposure. The dose consequences for the public and collocated worker are $<0.002$ rem and $<0.2$ rem, respectively. EGs are not exceeded and no safety-class or safety-significant SSCs are required. In addition, no SACs requiring TSR control are required.

\subsubsection{Container Drop Accident}

\subsubsection{Scenario Development}

This accident was considered in the PHA as separate events for transportation package drop and waste container drop. The consequences of either event are the same, and these events are therefore considered together in this evaluation.

This DBA event involves dropping a waste container or transportation package that results in the release of radioactive material. The transportation package is lifted from the transport vehicle utilizing the facility crane. The waste containers are transferred to the vault using the facility crane. The drop of a waste container or transportation package results from failure of the crane or lifting and handling equipment, and is considered an anticipated event for the proposed facility. In this postulated event, the waste container or transportation package is dropped to the ground breaching multiple layers of confinement and releasing radioactive material.

During the container drop scenario, shielding provided by the transportation package is assumed maintained in place. Therefore, dose to the facility worker, collocated worker, and public in this case is assumed to be only from intake of radiological material made airborne as a result of the container drop. Direct radiation exposure consequences and associated controls due to the handling accidents are addressed in Section 3.5.3.

\subsubsection{Analysis of Radiological Source Term and/or Chemical Exposure}

The MAR for release of radioactive material in this scenario is limited to the contents of a single waste container. An unmitigated analysis is performed for which the hazardous material's quantity, form, location, dispersibility, and interaction with available energy are considered, but no credit is taken for safety features that could mitigate the consequences of a hazard. The MAR is defined for each waste stream in ECAR-1559. Values used to calculate a ST for uptake in this accident are waste-stream specific as shown in Table 3-7. 
Table 3-7. Release factors for RH LLW disposal project drop scenarios.

\begin{tabular}{|c|c|c|c|c|}
\hline Waste Stream & DR & ARF & RF & \multicolumn{1}{|c|}{ Applicable MAR } \\
\hline Activated metals & 1.0 & $2 \mathrm{E}-3$ & 0.3 & $\begin{array}{l}\text { Contaminated, noncombustible solids [bounded by airborne release } \\
\text { of powder (DOE-HDBK-3010-94, p. 5-6, 4-9); applicable to } \\
\text { activated metals that are considered noncombustible] }\end{array}$ \\
\hline Resins & 1.0 & $1 \mathrm{E}-3$ & 1.0 & $\begin{array}{l}\text { Contaminated, combustible solids [bounded by suspension of loose } \\
\text { surface contamination (DOE-HDBK-3010-94, p. 5-4)] }\end{array}$ \\
\hline $\begin{array}{c}\text { Nonmetallic } \\
\text { wastes }\end{array}$ & 1.0 & $1 \mathrm{E}-3$ & 1.0 & $\begin{array}{l}\text { Contaminated, combustible solids [bounded by suspension of loose } \\
\text { surface contamination (DOE-HDBK-3010-94, p, 5-4)] }\end{array}$ \\
\hline
\end{tabular}

The DR represents the fraction of MAR that could be affected by the postulated accident and is a function of the accident initiator and the operational scenario being evaluated. DRs are determined based on engineering judgment, best available information, and prior analysis. The DR for the container drop scenario is evaluated at 1.0.It assumes that the drop is significant enough to fail the transportation package and the waste container, and $100 \%$ of the available source term is damaged enough to be released.

A LPF of 1.0 is a standard assumption for DOE facilities and activities and is appropriate for an outdoor event.

The ST and inhalation dose consequences are evaluated as discussed in Section 3.2.3; results are shown in Table 3-8.

Table 3-8. Inhalation dose consequences for container drop accident.

\begin{tabular}{|c|c|c|c|c|}
\hline \multirow{2}{*}{ Waste Stream } & Container & $\begin{array}{c}\text { Facility Worker, } \\
\text { rem/min }\end{array}$ & $\begin{array}{c}\text { Collocated } \\
\text { Worker, rem }\end{array}$ & Public, rem \\
\hline \multirow{2}{*}{ NRF metals } & 55 -ton cask liner & $2.9 \mathrm{E}+00$ & $1.9 \mathrm{E}-01$ & $4.6 \mathrm{E}-03$ \\
\cline { 2 - 5 } & New concept container & $8.1 \mathrm{E}+00$ & $5.4 \mathrm{E}-01$ & $1.3 \mathrm{E}-02$ \\
\hline \multirow{2}{*}{ NRF resins } & 55 -ton cask liner & $2.7 \mathrm{E}-01$ & $1.8 \mathrm{E}-02$ & $4.4 \mathrm{E}-04$ \\
\cline { 2 - 5 } & New concept container & $7.6 \mathrm{E}-01$ & $5.1 \mathrm{E}-02$ & $1.2 \mathrm{E}-03$ \\
\hline \multirow{2}{*}{ ATR activated metals } & $\begin{array}{c}\text { Single-contained HFEF-5 } \\
\text { cask liner }\end{array}$ & $1.6 \mathrm{E}+00$ & $1.0 \mathrm{E}-01$ & $2.3 \mathrm{E}-03$ \\
\hline \multirow{2}{*}{ ATR resins } & $\begin{array}{c}\text { NuPac } 14 / 210 \mathrm{~L} \text { Resin } \\
\text { Liner }\end{array}$ & $1.5 \mathrm{E}-01$ & $1.0 \mathrm{E}-02$ & $2.8 \mathrm{E}-04$ \\
\hline MFC activated metals & HFEF-5 cask liner & $2.0 \mathrm{E}+00$ & $1.4 \mathrm{E}-01$ & $3.0 \mathrm{E}-03$ \\
\hline \multirow{2}{*}{ MFC legacy waste (RSWF) } & $\begin{array}{c}\text { "24-over-16" cask liner in } \\
\text { modified FTC cask }\end{array}$ & $4.7 \mathrm{E}-01$ & $3.1 \mathrm{E}-02$ & $7.0 \mathrm{E}-04$ \\
\hline MFC legacy waste (SN cans) & HFEF-5 cask liner & $7.8 \mathrm{E}-03$ & $5.2 \mathrm{E}-04$ & $1.6 \mathrm{E}-05$ \\
\hline MFC future (FCF) & HFEF-5 cask liner & $3.0 \mathrm{E}-01$ & $2.0 \mathrm{E}-02$ & $5.7 \mathrm{E}-04$ \\
\hline MFC future (HFEF) & HFEF-5 cask liner & $7.9 \mathrm{E}-03$ & $5.3 \mathrm{E}-04$ & $1.6 \mathrm{E}-05$ \\
\hline
\end{tabular}


INL/EXT-10-19054

Revision 0

\subsubsection{Design Requirements}

There are no design requirements derived from this DBA to prevent or mitigate inhalation dose consequences.

\subsubsection{Control Selection and Classification}

Dose consequence EGs for the public and facility/collocated workers are 0.5 rem and 5 rem, respectively, for anticipated events. As shown in Table 3-8, the dose consequence to the nearest facility worker can be as high as 81 rem for a 10 minute exposure. The dose consequences for the public and collocated worker are $<0.02$ rem and $<1.0$ rem, respectively. As can be seen in the evaluation of dose to and the facility worker, the dose consequence may exceed EGs for this event when considering inhalation dose from uptake of radioactive material and the duration of the exposure. Therefore, safety-significant SSCs and/or SACs may be required. The controls suggested for this event include:

- Robust transportation package (safety-significant SSC)

- Waste acceptance criteria (safety analysis commitment).

\subsubsection{Direct Radiation Exposure During Waste Container Handling}

\subsubsection{Scenario Development}

Waste containers are routinely transferred from transportation packages to storage vaults using a variety of container handling equipment and appropriate shielding during the transfer operations. A handling equipment failure or the absence of appropriate shielding would result in increased radiation fields due to unshielded containers.

\subsubsection{Analysis of Radiological Source Term and/or Chemical Exposure}

Doses from direct radiation exposure during waste container handling are evaluated based on the maximum container contact exposure rate expected at the RH LLW disposal project of $30,000 \mathrm{R} / \mathrm{hr}$ (neutron and gamma) $(60,000 \mathrm{R} / \mathrm{hr}$ for NRF waste streams). The dose due to a container of material producing a $30,000 \mathrm{R} / \mathrm{hr}(60,000 \mathrm{R} / \mathrm{hr}$ for NRF waste streams) is evaluated at $10 \mathrm{~m}$ for the facility worker, $100 \mathrm{~m}$ for the collocated worker, and 4,000 $\mathrm{m}$ for the public as described in Section3.2.3.Direct radiation exposure rates for each container type and contents are shown in Table 3-9 and documented in ECAR-1559. The direct radiation exposure rates reported are for unshielded containers. For gamma radiation, $1 \mathrm{R} / \mathrm{hr}$ is conservatively equivalent to $1 \mathrm{rem} / \mathrm{hr}$. The HFEF-5 liners are modeled utilizing the material with the lowest contents density (MFC future) as this results in the highest exposure rate as described in ECAR-1559. 
Table 3-9. Direct radiation exposure rates due to unshielded containers.

\begin{tabular}{|c|c|c|c|c|}
\hline \multirow{2}{*}{ Material } & Container & $\begin{array}{c}\text { Facility Worker } \\
\text { Exposure Rate, } \\
\text { R/hr }\end{array}$ & $\begin{array}{c}\text { Collocated Worker } \\
\text { Exposure Rate, R/hr }\end{array}$ & $\begin{array}{c}\text { Public Exposure Rate, } \\
\text { R/hr }\end{array}$ \\
\hline NRF metals & 55 -ton cask liner & $3.47 \mathrm{E}+02$ & $2.65 \mathrm{E}+00$ & $9.88 \mathrm{E}-14$ \\
\hline NRF metals & New concept container & $6.45 \mathrm{E}+02$ & $5.04 \mathrm{E}+00$ & $1.86 \mathrm{E}-13$ \\
\hline NRF resins & 55 -ton cask liner & $3.61 \mathrm{E}+02$ & $2.95 \mathrm{E}+00$ & $1.49 \mathrm{E}-13$ \\
\hline NRF resins & New concept container & $6.75 \mathrm{E}+02$ & $5.67 \mathrm{E}+00$ & $2.83 \mathrm{E}-13$ \\
\hline ATR metals & HFEF-5 liner & $8.08 \mathrm{E}+01$ & $6.42 \mathrm{E}-01$ & $3.28 \mathrm{E}-14$ \\
\hline ATR resins & NuPac liner & $1.81 \mathrm{E}+02$ & $1.54 \mathrm{E}+00$ & $3.28 \mathrm{E}-14$ \\
\hline MFC metals & HFEF-5 liner & $8.08 \mathrm{E}+01$ & $6.42 \mathrm{E}-01$ & $6.06 \mathrm{E}-14$ \\
\hline $\begin{array}{c}\text { MFC legacy } \\
\text { (RSWF) }\end{array}$ & $\begin{array}{c}\text { "24-over-16" cask } \\
\text { liner in modified FTC } \\
\text { cask }\end{array}$ & $2.06 \mathrm{E}+02$ & $1.56 \mathrm{E}+00$ & $3.28 \mathrm{E}-14$ \\
\hline $\begin{array}{c}\text { MFC legacy (SN } \\
\text { cans) }\end{array}$ & HFEF-5 liner & $8.08 \mathrm{E}+01$ & $6.42 \mathrm{E}-01$ & $3.28 \mathrm{E}-14$ \\
\hline MFC future & HFEF-5 liner & $8.08 \mathrm{E}+01$ & $6.42 \mathrm{E}-01$ & $2.83 \mathrm{E}-13$ \\
\hline Maximum & \multicolumn{6}{|c|}{$6.75 \mathrm{E}+02$} & $5.67 \mathrm{E}+00$ & \\
\hline
\end{tabular}

\subsubsection{Design Requirements}

The hazard and accident analysis demonstrates that the dose consequences to the facility worker during waste container transfers exceed EGs. Therefore, shielding is required during transfer of waste containers from transportation casks into the vaults in order to mitigate direct radiation exposure to facility workers under normal and accident conditions.

\subsubsection{Control Selection and Classification}

As shown in Table 3-9, dose consequences to the nearest facility worker can be as high as 100 rem for a 10 minute exposure. This consequence level exceeds EGs (i.e., 5 rem to the facility worker for an anticipated event). Dose rates to the collocated worker due to compromised shielding would be low ( $\sim 5 \mathrm{rem}$ ). Dose rates to the public from direct radiation at an assumed 4,000 $\mathrm{m}$ would be negligible. Shielding is required to ensure that facility workers are not exposed to high radiation levels. For waste containers with $>30,000 \mathrm{R} / \mathrm{hr}$ (neutron and gamma) $(>60,000 \mathrm{R} / \mathrm{hr}$ for NRF waste streams) contact exposure rates, additional controls, such as maintaining minimum distances from the containers or addition of temporary shielding during transfer operations, may be required to ensure that EGs for facility workers are not exceeded. The controls suggested for this event include:

- Robust transportation package (safety-significant SSC)

- Waste container transfer system shielding (safety-significant SSC)

- Specific procedures for transferring waste containers with high contact exposure rates (TSR-level $\mathrm{SAC})$. 
INL/EXT-10-19054

Revision 0

\subsubsection{Severe Seismic Event}

\subsubsection{Scenario Development}

This event bounds the primary NPHs typically considered credible at the INL site. Other NPH events were considered as required by DOE O 420.1B and DOE G 420.1-2, "Guide for the Mitigation of Natural Phenomena Hazards for DOE Nuclear Facility and NonNuclear Facilities," and were determined to be beyond credible, or the effects would fall within the effects of these primary hazards. Of these potential NPH events, high winds, fires, lightning strikes, and floods are assumed to have little or no impact on the underground concrete vaults, leaving seismic events as posing the greatest potential to impose structural loads sufficient to cause waste container failure. A seismic event with sufficient energy to cause failure of the concrete vault and waste container is extremely unlikely. Even if such an event were to occur and the waste container and vault were both to fail, it is probable that the failure would result in at least a partial filling of backfill sand and soil into the vault that would prevent a significant release of radiological material.

\subsubsection{Analysis of Radiological Source Term and/or Chemical Exposure}

A severe seismic event is postulated to cause loss of vault shield plug integrity. Consequences to this postulated event are direct radiation exposure to a worker in the immediate vicinity of a failed shield plug.

\subsubsection{Design Requirements}

As delineated in the SDS, based on an initial review of the applicable facility hazards and in accordance with ANSI/ANS-2.26-2004, "Categorization of Nuclear Facility Structures, Systems, and Components for Seismic Design," the RH LLW disposal project seismic design category (SDC) is SDC-1. This determination is based on the assumption that a failure of a vault will not cause radiological material to be brought to the surface and that it will remain in place without causing significant radiological exposure to workers, the public, or the environment. Even though other NPH events were determined to be beyond credible, their impact on the RH LLW disposal project design will be in accordance with DOE-STD-1020-2002, "Natural Phenomena Hazards Design and Evaluation Criteria for Department of Energy Facilities" and DOE-STD-1021-1993, "Natural Phenomena Hazards Performance Categorization Guidelines For Structures, Systems, And Components," for a Performance Category-2 facility.

The vault shield plugs to be used are constructed of high-density concrete and placed in a solid array over the entire vault area. Failure of a shield plug requires that the shield plug rupture and be physically removed vertically from its installation because, while the shield plug is in place, it is laterally constrained from horizontal movement by the presence of adjacent shield plugs, facility boundary, and dirt and gravel around the perimeter providing stability. A strong seismic event is an assumed condition that could result in a failure of the concrete vault shield plugs. A seismic event with enough ground motion to fracture or rubbilize the vault shield plug is considered an extremely unlikely event. Other events that could potentially fracture a vault shield plug could not credibly cause the shield plug material to be completely removed and fail to provide shielding.

Dose to the facility worker in this case is assumed to be primarily from direct radiation exposure. Contact exposure rates with the waste container can be as high as $30,000 \mathrm{R} / \mathrm{hr}$ (neutron and gamma) $(60,000 \mathrm{R} / \mathrm{hr}$ for NRF waste streams). As shown in Table 3-9, it is possible that a facility worker could be exposed to high consequences in the immediate vicinity of a failed shield plug. At the distance of the 
INL/EXT-10-19054

Revision 0

collocated worker at $100 \mathrm{~m}$ and the public at $4,000 \mathrm{~m}$, dose rates would be low and negligible, respectively.

\subsubsection{Control Selection and Classification}

Dose consequence EGs for the public and workers are 5 rem and 25 rem, respectively, for unlikely events. As can be seen in the evaluation of dose to public and workers, the dose consequences may exceed EGs for this event when considering direct radiation exposure to facility workers. Therefore, safety-significant SSCs and/or SACs may be required. The control suggested for this event includes:

- Vault shield plug (safety-significant SSC).

\subsubsection{External Events}

Events under this category of accidents include plane crash, vehicle crash, and adjacent building fire/explosion. Plane crashes on the INL are judged to be beyond extremely unlikely due to diversion of air traffic and based on air transportation safety information. As described in Section 1.5, based on an assessment of aircraft impact probabilities at the MFC, an aircraft crash into RH LLW disposal project is considered beyond extremely unlikely (probability of $<10^{-6}$ per year) when considered as an accident initiator. Vehicle crashes and adjacent building fire/explosions do not have a significant impact on the waste containers buried at the RH LLW disposal project. There is no anticipated release of radioactive material from this category of accidents should they occur. The maximum dose from a hypothetical large break LOCA at the ATR is 7.5 rem at the RTA exclusion zone as documented in SAR-153, "Upgraded Final Safety Analysis Report for the Advanced Test Reactor." This location is also approximately 0.5 mile from the RH LLW disposal project site. This dose is less than the EGs for an extremely unlikely event and would not adversely impact the RH LLW disposal project beyond a possible need for evacuation. Therefore, there are no controls required for this category of events.

\subsection{Summary of Significant Facility Worker Hazards and Controls}

There are no significant facility worker hazards identified beyond those discussed in the DBAs in Section 3.5.As the facility design matures, further analyses will be performed evaluating the need for controls for the protection of facility workers.

\subsection{Summary of Safety Functions and SSCs and SACs}

A summary listing of the preliminary set of suggested controls, along with a statement of the necessary safety function, is provided in Table 3-10. 
Table 3-10. Preliminary hazard controls for RH LLW disposal project.

\begin{tabular}{|c|c|c|}
\hline Type & Hazard Control & Summary Safety Function \\
\hline $\begin{array}{l}\text { Safety-class } \\
\text { SSC }\end{array}$ & None & $\mathrm{N} / \mathrm{A}$ \\
\hline \multirow{3}{*}{$\begin{array}{l}\text { Safety- } \\
\text { significant } \\
\quad \text { SSC }\end{array}$} & Robust transportation package & $\begin{array}{l}\text { Prevent/mitigate direct radiation exposure } \\
\text { during transportation package handling } \\
\text { operations. }\end{array}$ \\
\hline & $\begin{array}{l}\text { Waste container transfer system } \\
\text { shielding }\end{array}$ & $\begin{array}{l}\text { Prevent/mitigate direct radiation exposure } \\
\text { during waste container handling operations. }\end{array}$ \\
\hline & Vault shield plug & $\begin{array}{l}\text { Prevent/mitigate direct radiation exposure } \\
\text { during vault storage. }\end{array}$ \\
\hline SAC & $\begin{array}{l}\text { Specific procedures for transferring } \\
\text { waste containers with high contact } \\
\text { exposure rates }\end{array}$ & $\begin{array}{l}\text { Prevent/mitigate direct radiation exposure } \\
\text { during waste container handling operations. }\end{array}$ \\
\hline $\begin{array}{c}\text { Safety } \\
\text { analysis } \\
\text { commitment }\end{array}$ & Waste acceptance criteria & $\begin{array}{l}\text { Mitigate inhalation dose consequences during } \\
\text { waste container handling operations }\end{array}$ \\
\hline
\end{tabular}

Safety-class SSCs are hazard controls for which credit is taken, either preventive or mitigative, to meet the EGs for the off-site public. Based on the results in this PSDR, EGs for the public are not exceeded for unmitigated releases. Therefore, no safety-class SSCs are identified for this facility.

Safety-significant SSCs are hazard controls for which credit is taken to prevent or mitigate postulated anticipated or unlikely accidents that could result in consequences to collocated or facility workers exceeding EGs. Based on the results in this PSDR, it is concluded that the potential exists for an accident that could result in direct radiation exposure exceeding these guidelines to the facility worker. The high-density concrete vault shield plugs are identified as a component that would protect the facility worker from these consequences after the waste containers are placed in the vaults. Any shielding required for waste container transfer systems (e.g., CVAS or equivalent shielding and systems for topunloading transportation packages) are identified as components that would protect the facility worker from these consequences during placement of the waste containers in the vaults. Finally, the transportation packages shielding is required to protect the facility worker from these consequences during transport and handling of waste containers. The vault shield plugs, shielding required for waste container transfer systems, and shielding required for transportation packages are, therefore, designated as safety-significant SSCs for design and facility planning purposes.

The primary mechanical system of the facility is related to operation of the hoisting system associated with the working platform that is used to lower the waste containers into the vaults. The system currently at RWMC is owned by the Office of Naval Reactors and is planned to be transferred to the new disposal facility for use in waste placement operations. This system has not been designated as a safety SSC for handling the NRF activated metal waste. Since the waste stream is the same and handling operations will be similar in the proposed new facility, it is not expected that the safety designation would change. Preliminary consequence evaluations made for a single waste container also supports this position. Development of other waste container transfer systems will need to ensure that all applicable mechanical systems are designed using the appropriate protocols. Any ancillary equipment specifically required to interface with the waste container for transport and unloading, other than the typical hoisting and rigging components, will be provided by the generating facility. 
The pre-cast concrete storage vaults are considered defense-in-depth design features and perform the safety function of shielding and confinement; however, they are not derived as safety-significant SSCs. The vaults are located below ground surface, isolating contents from facility workers, and, upon failure, would not impose any risk of fatality or serious injury to workers. There are no failure scenarios for the vaults that result in a loss of function in an emergency that may be needed to preserve the health and safety of workers. Furthermore, in the improbable event of vault or shield plug failure, there would be no significant offsite consequences.

It is possible that the design-basis contact exposure rates of $30,000 \mathrm{R} / \mathrm{hr}$ (neutron and gamma) $(60,000 \mathrm{R} / \mathrm{hr}$ for NRF waste streams) can be exceeded for individual waste containers. In this case, specific procedures for transferring waste containers with high contact exposure rates are required to protect facility workers from direct radiation exposures. The requirement for specific procedures for handling high contact exposure rate containers is therefore a TSR-level SAC.

Although the inhalation dose consequences for handling individual containers are low, the WAC are identified as a safety analysis commitment for ensuring that the radionuclide distribution and concentration in individual waste containers do not exceed the maximum values evaluated in ECAR-1559. This, in turn, ensures that the inhalation dose consequence EGs for the facility worker are not exceeded.

\subsection{Accidents Beyond the Design Basis}

Consideration of accidents beyond the design basis provides a perspective of the residual risk associated with the operation of the facility. In the case of the RH LLW disposal project, this involves further consideration of the DBAs addressed above.

A review of the hazard and accident analysis has identified one scenario involving a seismic event that exceeds the facility and equipment capacity. Operational beyond DBAs were not considered since the increase in consequences from many of the hazards events and the specific accidents would not be physically possible because the events already analyzed consider maximum bounding inventories.

From the hazard analysis, a design basis seismic event is postulated to cause loss of vault shield plug integrity and result in direct radiation exposure to a worker in the immediate vicinity of a failed shield plug. A beyond design basis seismic event that could cause seismic failure of the concrete vault and waste container could result in a radioactive material release and/or direct radiation exposure. Failure of the shield plug and concrete vault would result in a potential unshielded configuration of radioactive material. Failure of the waste container would result in potential release of radioactive material from the breached container. The loss of shielding due to the failed shield plug and vault would be limited by the partial filling of the hole with shield plug and vault debris as well as sand and soil. The debris filling the vault would prevent a direct line of exposure between the worker and the waste contents and provide a measure of shielding from the concrete rubble. A significant release of radiological material due to the breach of waste containers would be limited by the partial filling of backfill sand and soil into the vault. The backfilled sand and soil would provide a barrier between the worker and the airborne radioactive material preventing its leak to the atmosphere. The potential consequences to a worker due to the loss of shielding and breached waste container would be high. The majority of the dose to the worker would be a result of the direct radiation exposure; the inhalation dose due to airborne radioactive material would be negligible. At the distance of the collocated worker at $100 \mathrm{~m}$ and the public at 4,000 $\mathrm{m}$, dose rates would be negligible. 
INL/EXT-10-19054

Revision 0

The vault shield plugs to be used are robust and placed in a solid array over the entire waste disposal area. Failure of a shield plug requires that the plug rupture and be physically removed vertically from its installation because, while the plug is in place, it is laterally constrained from horizontal movement by the presence of adjacent plugs and the facility boundary. A strong seismic event is an assumed condition that could result in a failure of the high-density concrete vault shield plugs. If a lower probability seismic event occurred and the shield plug failed, the consequences could be of the magnitude discussed in Section 3.5.4.

\subsection{References}

29 CFR 1910.119, "Process Safety Management of Highly Hazardous Chemicals," Code of Federal Regulations, Office of the Federal Register, August 2006.

49 CFR 173.424, "Excepted packages for radioactive instruments and articles," Code of Federal Regulations, Office of the Federal Register, October, 2011.

ANSI/ANS 2.26-2004, "Categorization of Nuclear Facility Structures, Systems, and Components for Seismic Design," American National Standards Institute/American Nuclear Society, December 2004.

DOE-HDBK-3010-2004, "Airborne Release Fractions/Rates and Respirable Fractions for Nonreactor Nuclear Facilities," U.S. Department of Energy.

DOE Guide 420.1-2, "Guide for the Mitigation of Natural Phenomena Hazards for DOE Nuclear Facility and NonNuclear Facilities," U.S. Department of Energy, March 2000.

DOE Order 420.1B, “Facility Safety,” U.S. Department of Energy, December 2005.

DOE Order 435.1, "Radioactive Waste Management," Change 1, U.S. Department of Energy, July 1999.

DOE Order 440.1B, “Worker Protection Program for DOE,” U.S. Department of Energy, May 2007.

DOE-STD-1020-2002, "Natural Phenomena Hazards Design and Evaluation Criteria for Department of Energy Facilities,” U.S. Department of Energy, January 2002.

DOE-STD-1021-93, Reaffirmed with Errata, "Natural Phenomena Hazards Performance Categorization Guidelines for Structures, Systems, and Components,” U.S. Department of Energy, April 2002.

DOE-STD-1027-92, "Hazard Categorization and Accident Analysis Techniques for Compliance with DOE Order 5480.23, Nuclear Safety Analysis Reports," U.S. Department of Energy, September 1997.

DOE-STD-1189-2008, "Integration of Safety into the Design Process," U.S. Department of Energy, March 2008.

ECAR-1559, "Evaluation of Facility Inventory and Radiological Consequences to Support RHLLWDF Safety-Basis and NEPA Documentation," Rev. 1, January 2012.

ICRP-68, "Dose Coefficients for Intakes of Radionuclides by Workers," International Commission on Radiological Protection, 1994. 
INL/EXT-10-19054

Revision 0

ICRP-72, “Age-dependent Doses from Intakes of Radionuclides,” International Commission on Radiological Protection, 1996.

INL, 2009, Radiological Safety Analysis Computer (RSAC) Program Version 7.0 Users' Manual, INL/EXT-09-15275, Idaho National Laboratory, Rev. 0, March 2009.

INL, 2010a, Preliminary Hazard Assessment for the Remote-handled Low-level Waste Disposal Project, INL/EXT-07-12903, Idaho National Laboratory, Rev. 2, February 2010.

INL, 2010b, Safety Design Strategy for the Remote-Handled Low-Level Waste Disposal Project, INL/EXT-09-17117, Idaho National Laboratory, Rev. 31, April 2010July 2012.

INL, 2010c, Conceptual Design Report for the Remote-Handled Low-Level Waste Disposal Project, INL/EXT-07-12901, Rev. 2, June 2010.

NS-18101, “INL Safety Analysis Process,” Idaho National Laboratory, current revision.

NS-18104, "Nuclear Safety Engineering,” Idaho National Laboratory, current revision.

OS-QSD-05-121, CCN 202983, M. L. Adams (DOE-ID Contracting Officer) letter to L. A. Sehlke, "Nuclear Safety Rule Supplementation Information," October 11, 2005.

TEV-1119, “Assessment of Potential for Inadvertent Nuclear Criticality in the RHLLWDF,” Rev. 0, December 2010. 
INL/EXT-10-19054

Revision 0

\section{SAFETY STRUCTURES, SYSTEMS, AND COMPONENTS FOR PRELIMINARY DESIGN}

\subsection{Introduction}

This chapter classifies the suggested safety-class and safety-significant SSCs and SACs associated with the RH LLW disposal project. The determination of the safety-class and safety-significant SSCs and SACs was based on the results of the analyses in Chapter 3 of this document. Criteria for the selection of SSCs and TSRs established for the INL are described in Chapter 3.

\subsection{Safety-Class Structures, Systems, and Components}

Safety-class SSCs generally include those SSCs whose preventive or mitigative functions are necessary to maintain public exposures to hazardous materials below the off-site EGs. Consistent with the definitions of EGs and the results of the hazards and accident analyses presented in Chapter 3, no SSCs in RH LLW disposal project have been designated as safety-class.

\subsection{Safety-Significant Structures, Systems, and Components}

The EGs and selection criteria used to determine when safety-significant SSCs are necessary are presented in Chapter 3. Based on these criteria and the hazards and accident analyses in Chapter 3, the following suggested controls are designated safety-significant SSCs:

- Vault shield plugs

- Waste container transfer system shielding

- Robust transportation packages.

A detailed description of these safety-significant SSCs and a complete discussion of how they meet the functional requirements and perform their safety function are provided in the following sections. A summary of each safety-significant SSC is provided below in Table 4-1. 
INL/EXT-10-19054

Revision 0

Table 4-1. Safety-significant SSCs and performance criteria.

\begin{tabular}{|c|c|c|c|c|}
\hline $\begin{array}{c}\text { Safety-Significant } \\
\text { SSC }\end{array}$ & $\begin{array}{c}\text { Accident Prevented or } \\
\text { Mitigated }\end{array}$ & Safety Function & $\begin{array}{c}\text { Functional } \\
\text { Requirements }\end{array}$ & $\begin{array}{c}\text { Performance } \\
\text { Criteria Requiring } \\
\text { TSR }\end{array}$ \\
\hline Vault shield plugs & $\begin{array}{l}\text { Direct radiation } \\
\text { exposure due to loss of } \\
\text { vault shield plug } \\
\text { integrity caused by } \\
\text { severe seismic event }\end{array}$ & $\begin{array}{l}\text { Prevent/mitigate } \\
\text { direct radiation } \\
\text { exposure during } \\
\text { vault storage. }\end{array}$ & $\begin{array}{l}\text { Provide sufficient } \\
\text { thickness of } \\
\text { shielding media to } \\
\text { reduce external dose } \\
\text { to acceptable level. }\end{array}$ & $\begin{array}{l}\text { Verify design of } \\
\text { vault plug shielding. } \\
\text { Verify placement of } \\
\text { vault shield plug as } \\
\text { required. }\end{array}$ \\
\hline $\begin{array}{l}\text { Waste container } \\
\text { transfer system } \\
\text { shielding }\end{array}$ & $\begin{array}{l}\text { Direct radiation } \\
\text { exposure due to waste } \\
\text { container drop. } \\
\text { Direct radiation } \\
\text { exposure during waste } \\
\text { container transfer from } \\
\text { transportation package }\end{array}$ & $\begin{array}{l}\text { Prevent/mitigate } \\
\text { direct radiation } \\
\text { exposure during } \\
\text { waste container } \\
\text { handling operations. }\end{array}$ & $\begin{array}{l}\text { Provide sufficient } \\
\text { thickness of } \\
\text { shielding media to } \\
\text { reduce external dose } \\
\text { to acceptable level. }\end{array}$ & $\begin{array}{l}\text { Verify design of } \\
\text { transfer system } \\
\text { shielding. } \\
\text { Verify placement of } \\
\text { transfer system as } \\
\text { required. }\end{array}$ \\
\hline $\begin{array}{l}\text { Robust } \\
\text { transportation } \\
\text { packages }\end{array}$ & $\begin{array}{l}\text { Direct radiation } \\
\text { exposure due to } \\
\text { transportation package } \\
\text { drop. } \\
\text { Direct radiation } \\
\text { exposure during waste } \\
\text { container transfer from } \\
\text { transportation package }\end{array}$ & $\begin{array}{l}\text { Prevent/mitigate } \\
\text { direct radiation } \\
\text { exposure during } \\
\text { transportation } \\
\text { package handling } \\
\text { operations. }\end{array}$ & $\begin{array}{l}\text { Provide sufficient } \\
\text { thickness of } \\
\text { shielding media to } \\
\text { reduce external dose } \\
\text { to acceptable level. }\end{array}$ & $\begin{array}{l}\text { Verify design of } \\
\text { transportation } \\
\text { package shielding. } \\
\text { Verify placement of } \\
\text { transportation } \\
\text { package as required. }\end{array}$ \\
\hline
\end{tabular}

\subsubsection{Vault Shield Plugs}

The vault shield plugs are a suggested passive safety-significant SSC due to the RH LLW disposal project design.

\subsubsection{Safety Function}

The vault shield plugs are required to ensure that facility workers are not exposed to high radiation consequences (Chapter 3). The vault shield plugs provide radiation shielding between the waste containers in the vault and the top surface of the plug. The vault shield plugs are required once the waste containers are placed in the vault during all normal and abnormal events.

\subsubsection{System Description}

The vault shield plug detailed design is described in Chapter 2.

The vault shield plugs are designed to provide adequate shielding of waste containers in a structural configuration to permit removal and placement of the plug as required to store waste containers in the vaults. The vault shield plug design must interface with the vault top opening and must be capable of being lifted by the facility crane. A temporary shield plug can be utilized for operational activities as long as it meets the same safety functional requirements specified in TFR-483 and SPC-1437. 
INL/EXT-10-19054

Revision 0

\subsubsection{Functional Requirements}

The functional requirement of the vault shield plug is to provide sufficient thickness of a shielding material to reduce the dose to acceptable levels corresponding to the prolonged presence of a facility worker immediately adjacent to the plug top surface.

\subsubsection{System Evaluation}

Safety significant SSCs are designed to reliably perform their safety function under normal and credible accident conditions. This subsection summarizes the safety design analysis to demonstrate the adequacy of the SSC's ability to reliably perform its safety function. Performance criteria are identified to meet functional requirements.

\subsection{Conservative Design Features}

The vault shield plugs are designed to withstand design basis loadings with an appropriate margin of safety. Consequently, the vault shield plugs design incorporates multiple levels of protection against normal and credible accident conditions. The vault plug shielding design is anticipated to be comparable to the material specification and thickness of the existing RWMC vault shield plug design. The type of shielding is determined by the characteristics of the radiation, structural requirements, fire protection requirements, and radiation damage potential. Since shielding is an integral part of their design, the vault shield plugs are designed and installed to at least the same level of natural phenomenon qualification as the RH LLW disposal project structure. The vault shield plugs design also complies with the requirements in ANSI/ANS 6.4.2-2006, "Specification for Radiation Shielding Materials."

\subsection{Safe Failure Modes}

The only safety failure mode for the vault shield plugs is loss of shielding capability. The passive design feature of the vault shield plugs ensures that the shielding safety function will be performed as long as the approved vault shield plugs are used. The vault shield plugs are also designed to perform their function under all normal and credible accident conditions, including design-basis accidents.

\subsection{Environmental Design}

As stated above, the vault shield plugs are designed to perform their safety functions with no credible failure mechanism that could lead to common cause failures under postulated service conditions. The vault shield plugs are designed for the worst-case environmental conditions that could exist for the postulated credible accident scenarios.

\subsection{Support Systems}

The vault shield plugs rely on support systems to perform their safety function. Devices to monitor individual exposures to external radiation shall comply with the requirements of the INL Radiation Protection Program (SAR-400, Chapter 7).

However, since failure of the vault shield plugs to perform their safety function leads only to accidents with the potential for significant localized consequences, these support systems are not classified as safety significant. 
INL/EXT-10-19054

Revision 0

\subsection{Interface Design}

The safety design of the vault shield plug minimizes interfaces between itself and non-safety SSCs. Interfaces include the lifting crane hook and the vault plug recess. Vault shield plug handling equipment shall enable remote handling and transfer of plug between filled vault and low radiation inspection/maintenance/storage areas. Evaluation of these interfaces shows that failures that could prevent the safety significant SSC from performing its safety function are precluded by the vault shield plug design as well as INL safety management programs such as the hoisting and rigging program (SAR-400, Chapter 12). The vault system is designated defense-in-depth with the same level of seismic design qualification as the vault plug to ensure the vault plug performance goal is preserved.

\subsection{Specific Criteria}

The vault shield plug is designed to meet the specific safety requirements in ANSI/ANS 6.4.2-2006. The intent is to apply this design standard in a manner that will ensure that the vault shield plug will perform its required safety function. Vault shield plug design shall also comply with material specifications in Table 5.1, DOE Guide 420.1-1, "Nonreactor Nuclear Safety Design Criteria and Explosives Safety Criteria Guide for use with DO O 420.1, Facility Safety." The waste container should not be transferred from the cask to a vault having a damaged vault shield plug. If any evidence of a damaged vault shield plug exists, process operation of the RH LLW disposal project facility shall be discontinued until the damage condition has been resolved. A vault shield plug must be considered damaged if:

1. The vault shield plug does not provide adequate shielding.

2. The vault shield plug cannot be placed into nor removed from the vault as required.

\subsubsection{Controls (TSRs)}

The vault shield plug safety function shall be a limiting condition for operation (LCO) requirement in the RH LLW disposal project TSR. The RH LLW shall have one vault shield plug for each filled vault. The vault shield plug shall provide radiation shielding between the waste container(s) in the vault and the top surface of the plug. Vault shield plug design shall be capable of being periodically inspected in a low radiation environment (satisfactory to enable worker presence). Vault shield plug shielding capability shall be verified prior to and after placement in a filled vault.

\subsubsection{Waste Container Transfer System Shielding}

The waste container transfer system shielding is suggested as a safety-significant SSC due to the RH LLW disposal project design. Examples of the waste container transfer system include the RWMC CVAS, other similar systems that may be developed for future cask configurations, and similar apparatus for top-unloading transportation packages.

\subsubsection{Safety Function}

The waste container transfer system is required to ensure that facility workers are not exposed to high direct radiation consequences (Chapter 3). The waste container transfer system provides the necessary radiation shielding between the waste containers and the exterior surface of the transfer system. The transfer system is operated remotely to reduce worker dose. The transfer system is required to move the waste container from the transportation package and into the vault interior. 
INL/EXT-10-19054

Revision 0

\subsubsection{System Description}

The waste container transfer system shielding detailed design is described in Section 2.4.

The waste container transfer system shielding is designed to have sufficient thickness of shielding material and structural support to permit movement and operation of the transfer system with a filled waste container.

\subsubsection{Functional Requirements}

The functional requirement of the waste container transfer system is to provide sufficient thickness of a shielding material to reduce the dose $(\geq 30,000 \mathrm{R} / \mathrm{hr}$ neutron and gamma radiation at the surface of a waste container; $\geq 60,000 \mathrm{R} / \mathrm{hr}$ for NRF waste streams) to acceptable levels corresponding to the prolonged presence of a facility worker immediately adjacent to the transfer system surface.

\subsubsection{System Evaluation}

Safety significant SSCs are designed to reliably perform their safety function under normal and credible accident conditions. This subsection summarizes the safety design analysis to demonstrate the adequacy of the SSC's ability to reliably perform its safety function. Performance criteria are identified to meet functional requirements.

\subsection{Conservative Design Features}

The waste container transfer system shielding must be designed to withstand design basis loadings with an appropriate margin of safety. Consequently, the waste container transfer system shielding design incorporates multiple levels of protection against normal and credible accident conditions. The waste container transfer system shielding design is anticipated to be comparable to the material specification and thickness of the existing RWMC transfer system design. The type of shielding is determined by the characteristics of the radiation, structural requirements, and radiation damage potential. The waste container transfer system shielding design also complies with the requirements in ANSI/ANS 6.4.2-2006.

\subsection{Safe Failure Modes}

The only safety failure mode for the waste container transfer system shielding is loss of shielding capability. The passive design feature of the waste container transfer system shielding ensures that the shielding safety function will be expected to be performed as long as the approved waste container transfer system is used. The waste container transfer system shielding is also designed to perform its function under all normal and credible accident conditions, including design-basis accidents.

\subsection{Environmental Design}

As stated above, the waste container transfer system shielding is designed to perform its safety functions with no credible failure mechanism that could lead to common cause failures under postulated service conditions. The waste container transfer system shielding is designed for the worst-case environmental conditions that could exist for the postulated credible accident scenarios. 
INL/EXT-10-19054

Revision 0

\subsection{Support Systems}

The waste container transfer system shielding relies on support systems to perform its safety function. Devices to monitor individual exposures to external radiation shall comply with the requirements of the INL Radiation Protection Program (SAR-400). However, since failure of the waste container transfer system shielding to perform its safety function leads only to accidents with the potential for significant localized consequences, these support systems are not classified as safety significant.

\subsection{Interface Design}

The safety design of the waste container transfer system shielding minimizes interfaces between itself and non-safety SSCs. Interfaces include the transportation package and the waste container. Transfer system handling equipment shall enable handling and transfer of the transfer system between vault and low radiation inspection/maintenance/storage areas. Evaluation of these interfaces shows that failures that could prevent the safety significant SSC from performing its safety function are precluded by the transfer system design and INL safety management programs such as the hoisting and rigging (SAR-400, Chapter 12).

\subsection{Specific Criteria}

The waste container transfer system shielding is designed to meet the specific safety requirements in ANSI/ANS 6.4.2-2006. The intent is to apply this design standard in a manner that will ensure that the waste container transfer system shielding will perform its required safety function. Transfer systems must be capable of being removed and placed over the vault. The waste container should not be transferred from the transportation package or a vault using a damaged waste container transfer system. If any evidence of a damaged transfer system exists, process operation of the RH LLW disposal project shall be discontinued until the damage condition has been resolved. A transfer system must be considered damaged if:

1. The system does not provide adequate shielding.

2. The transfer system handling equipment is not operational.

3. The transfer system cannot adequately interface with the required transportation package.

No additional supplemental design criteria, as specified in DOE Guide 420.1-1, Chapter 5, apply to the design of radioactive shielding.

\subsubsection{Controls (TSRs)}

The transfer system safety function shall be a LCO requirement in the RH LLW disposal project TSR. The transfer system shall provide radiation shielding during transfer of the waste container between the transportation package and the vault. Transfer system design shall be capable of being periodically inspected in a low radiation environment (satisfactory to enable worker presence). Transfer system shielding capability shall be verified prior to placement on a transportation package.

\subsubsection{Transportation Packages}

The transportation packages shielding is suggested as a safety-significant SSC due to the RH LLW disposal project design. 
INL/EXT-10-19054

Revision 0

\subsubsection{Safety Function}

The transportation packages provide the necessary radiation shielding between the waste containers and the exterior surface of the transportation packages to ensure that facility workers are not exposed to high radiation consequences (Chapter 3). The transportation packages are opened remotely to reduce worker dose. The transportation packages are required to permit the movement of the waste containers to/from the RH LLW disposal project.

\subsubsection{System Description}

The NRF transportation package shielding detailed design is described in Chapter 2. Design of other transportation packages will be determined as other waste streams are identified.

The transportation package shielding is designed to have sufficient thickness of shielding material and structural support to permit transport of waste containers from the waste generator to the RH LLW disposal project site.

\subsubsection{Functional Requirements}

The shielding functional requirement of the transportation packages is to provide sufficient thickness of a shielding material to reduce the dose to acceptable levels corresponding to the prolonged presence of a facility worker immediately adjacent to the transportation package surface.

\subsubsection{System Evaluation}

Safety significant SSCs are designed to reliably perform their safety function under normal and credible accident conditions. This subsection summarizes the safety design analysis to demonstrate the adequacy of the SSC's ability to reliably perform its safety function. Performance criteria are identified to meet functional requirements.

\subsection{Conservative Design Features}

The transportation packages must be designed to withstand design basis loadings with an appropriate margin of safety. Consequently, the transportation packages design incorporates multiple levels of protection against normal and credible accident conditions. The type of shielding is determined by the characteristics of the radiation, structural requirements, and radiation damage potential. The transportation packages shielding design also complies with the requirements in ANSI/ANS 6.4.2-2006.

\subsection{Safe Failure Modes}

The only safety failure mode for the transportation packages is loss of shielding capability. The passive design feature of transportation packages ensures that the shielding safety function will be expected to be performed as long as the approved transportation package is used. The transportation packages are also designed to perform their safety function under all normal and credible accident conditions, including design-basis accidents.

\subsection{Environmental Design}

As stated above, the transportation packages are designed to perform their safety functions with no credible failure mechanism that could lead to common cause failures under postulated service 
INL/EXT-10-19054

Revision 0

conditions. The transportation package is designed for the worst-case environmental conditions that could exist for the postulated credible accident scenarios.

\subsection{Support Systems}

The transportation packages rely on support systems to perform their safety function. Devices to monitor individual exposures to external radiation shall comply with the requirements of the INL Radiation Protection Program (SAR-400, Chapter 7); however, because failure of the transportation packages to perform their safety function leads only to accidents with the potential for significant localized consequences, these support systems are not classified as safety significant.

\subsection{Interface Design}

The safety design of the transportation package shielding minimizes interfaces between itself and non-safety SSCs. Interfaces include the waste container transfer system, the waste container, and the crane lifting hooks. The facility crane shall enable handling and transfer of transportation packages between vault and low radiation inspection/maintenance/storage areas. Evaluation of these interfaces shows that failures that could prevent the safety significant SSC from performing its safety function are precluded by transportation package shielding design and INL safety management programs such as the hoisting and rigging (SAR-400, Chapter 12).

\subsection{Specific Criteria}

The transportation packages shielding is designed to meet the specific safety requirements in ANSI/ANS 6.4.2-2006. The intent is to apply this design standard in a manner that will ensure that the transportation packages will perform their required safety function. The transportation package must be capable of being interfaced with the waste container transfer system. The waste container should not be transferred from a damaged transportation package. If any evidence of a damaged transportation package exists, process operation of the RH LLW disposal project facility shall be discontinued until the damage condition has been resolved. The transportation package must be considered damaged if:

1. The transportation package does not provide adequate shielding

2. The transportation package handling equipment is not operational.

3. The transportation package cannot adequately interface with the waste container transfer system.

No additional supplemental design criteria, as specified in DOE Guide 420.1-1, Chapter 5, apply to the design of radioactive shielding.

\subsubsection{Controls (TSRs)}

The transportation package safety function shall be a SAC requirement in the RH LLW disposal project TSR. Waste containers are intended to be transferred into the RH LLW disposal project site from other facilities in transportation packages. Only approved transportation packages meeting the RH LLW disposal project requirements are permitted entry and use. The transportation package shall provide radiation shielding during transfer of the waste container between the transportation package and the transfer system. The transportation package shielding design shall be capable of being periodically inspected in a low radiation environment (satisfactory to enable worker presence). The transportation 
INL/EXT-10-19054

Revision 0

package shielding capability shall be verified and documented prior to receipt of a waste container in the transportation package at the RH LLW disposal project facility.

\subsection{Specific Administrative Controls}

The EGs and selection criteria used to determine when SACs are necessary are presented in Chapter 3.Based on these criteria, the following is suggested as a SAC:

- $\quad$ Specific procedures for transferring waste containers with high contact exposure rates.

\subsubsection{Specific Procedures for Transferring Waste Containers with High Contact Exposure Rates}

For containers with $>30,000 \mathrm{R} / \mathrm{hr}$ (neutron and gamma) ( $>60,000 \mathrm{R} / \mathrm{hr}$ for NRF waste streams) contact exposure rates, additional controls beyond the waste container transfer system shielding may be required to ensure that EGs for facility workers are not exceeded.

\subsubsection{Safety Function}

Specific procedures for transferring waste containers with high contact exposure rates are required to ensure that facility workers are not exposed to high radiation levels.

\subsubsection{SAC Description}

The safety-significant SSC for waste container transfer system shielding was derived as an SAC since the risk binning in the hazard analysis indicated that risk reduction needed to be at the level provided by a safety SSC if an appropriate SSC were available.

\subsubsection{Functional Requirements}

The functional requirement for this SAC is to prevent/mitigate direct radiation exposure due to normal and abnormal conditions during waste container handling operations.

\subsubsection{SAC Evaluation}

Incorporating shielding requirements in the form of approved procedures serves to control facility worker direct radiation exposure to within the EGs for the hazard evaluation. Controls may include, but are not limited to, personnel protective equipment, maintaining adequate distance from open casks/vaults, and/or limiting facility worker time of exposure. Devices to monitor individual exposures to external radiation and work plans and procedures for limiting exposure shall comply with the requirements of the INL Radiation Protection Program (SAR-400, Chapter 7).Compliance with this control ensures that unallowable worker direct radiation exposures do not occur in the facility.

\subsection{References}

ANSI/ANS 6.4.2-2006, "Specification for Radiation Shielding Materials," American National Standards Institute/American Nuclear Society, 2006.

DOE Guide 420.1-1, "Nonreactor Nuclear Safety Design Criteria and Explosives Safety Criteria Guide for use with DOE O 420.1, Facility Safety," March 2000. 
INL/EXT-10-19054

Revision 0

SAR-400, “INL Standardized Safety Analysis Report,” Rev. 1, October, 2008. 
INL/EXT-10-19054

Revision 0

\section{PRELIMINARY DERIVATION OF TECHNICAL SAFETY REQUIREMENTS}

The RH LLW disposal project TSRs will be established during final design to define the conditions, boundaries, and administrative controls (ACs) necessary to ensure the safe operation of the RH LLW disposal project. The TSRs will consist of LCOs that define the boundaries for operation, surveillance requirements (SRs), and a set of requirements for ACs under which the RH LLW disposal project will be operated. This chapter, to be developed as part of the PDSA, will provide information necessary to support the TSR document that will also be developed as part of the PDSA. Therefore, as documented in DOE-STD-1189-2008, the remainder of this chapter is not required for preliminary design in this PSDR. 
INL/EXT-10-19054

Revision 0

\section{DESIGN FOR THE PREVENTION OF INADVERTENT CRITICALITY}

Based on the facility hazard evaluation documented in Chapter 3 and the conclusions in TEV-1119, "Assessment of Potential for Inadvertent Nuclear Criticality in the RH-LLW Disposal Project," no controls for the prevention of an inadvertent nuclear criticality for the RH LLW disposal project are required. In the conceptual stage of the facility design, the PHA indicates that the waste streams for the facility do not contain sufficient quantities of fissionable material to make nuclear criticality a credible accident. As the design-build process proceeds, the commitment for further criticality safety assessments will be evaluated for design and waste inventory differences which will be properly reflected in this document.

The RH LLW disposal project does not process or package any fissile material received. The mission of the facility is to store LLW in isolated underground disposal vaults. As such, no engineered or administrative criticality concerns have been identified. If a criticality concern is determined in future design efforts, the facility criticality safety program will comply with the requirements of Chapter 6 , "Prevention of Inadvertent Criticality," of SAR-400 which has been standardized and describes the overall INL Criticality Safety Program. 
INL/EXT-10-19054

Revision 0

\section{APPENDIX A. SAFETY MANAGEMENT PROGRAM ROADMAP}

The overall safety management programs that will support safe operation of the RH LLW disposal project are described in SAR-400, "INL Standardized Safety Analysis Report." Table A-1 below provides a roadmap of the SAR-400 safety management programs applicable to the safe operation of the RH LLW disposal project.

Table A-1.Safety management program roadmap.

\begin{tabular}{|c|c|c|}
\hline $\begin{array}{l}\text { Occupational Radiation } \\
\text { Protection Program }\end{array}$ & $\begin{array}{l}\text { - As low as reasonably achievable (ALARA) } \\
\text { analysis and vault shield plug, waste } \\
\text { container transfer system, and transportation } \\
\text { package shielding analysis } \\
\text { - SAR-400, Chapter 7, "Radiation Protection" }\end{array}$ & $\begin{array}{l}\text { ALARA analysis and vault } \\
\text { shield plug, waste container } \\
\text { transfer system, and } \\
\text { transportation package } \\
\text { shielding analysis to be } \\
\text { developed during Critical } \\
\text { Decision (CD)-2 }\end{array}$ \\
\hline $\begin{array}{l}\text { Worker Safety and Health } \\
\text { Program }\end{array}$ & - SAR-400, Chapter 11, "Operational Safety” & \\
\hline Criticality Safety Program & $\begin{array}{l}\text { - Criticality evaluation } \\
\text { - SAR-400, Chapter 6, "Prevention of } \\
\text { Inadvertent Criticality" }\end{array}$ & $\begin{array}{l}\text { Criticality evaluation } \\
\text { documented in TEV-1119. }\end{array}$ \\
\hline $\begin{array}{l}\text { Radioactive Waste } \\
\text { Management Program }\end{array}$ & $\begin{array}{l}\text { - SAR-400, Chapter 9, "Radioactive and } \\
\text { Hazardous Waste Management" }\end{array}$ & \\
\hline Fire Protection Program & $\begin{array}{l}\text { - Fire safety analysis } \\
\text { - SAR-400, Chapter 11, "Operational Safety" }\end{array}$ & $\begin{array}{l}\text { Preliminary FHA documented } \\
\text { in HAD- } 474\end{array}$ \\
\hline $\begin{array}{l}\text { Environmental Protection } \\
\text { Program }\end{array}$ & $\begin{array}{l}\text { - Performance assessment } \\
\text { - SAR-400, Chapter 9, "Radioactive and } \\
\text { Hazardous Waste Management" }\end{array}$ & $\begin{array}{l}\text { Performance assessment } \\
\text { documented in } \\
\text { DOE/ID-11421 }\end{array}$ \\
\hline $\begin{array}{l}\text { In-service Testing, Inspection } \\
\text { and Maintenance }\end{array}$ & $\begin{array}{l}\text { - SAR-400, Chapter 10, "Initial Testing, In- } \\
\text { Service Surveillance, and Maintenance" }\end{array}$ & \\
\hline Engineering Program & $\begin{array}{l}\text { - INL/EXT-07-12901, “Conceptual Design } \\
\text { Report for the Remote-Handled Low-Level } \\
\text { Waste Disposal Project" }\end{array}$ & \\
\hline $\begin{array}{l}\text { Quality Assurance and } \\
\text { Performance Assessment }\end{array}$ & $\begin{array}{l}\text { - BEA-approved design-build subcontractor's } \\
\text { QAPP (during construction) } \\
\text { - SAR-400, Chapter 14, "Quality Assurance" } \\
\text { (during operations) }\end{array}$ & \\
\hline Emergency Management & $\begin{array}{l}\text { - SAR-400, Chapter 15, "Emergency } \\
\text { Preparedness Program" }\end{array}$ & \\
\hline $\begin{array}{l}\text { Management, Organization } \\
\text { and Institutional Safety } \\
\text { Provisions }\end{array}$ & $\begin{array}{l}\text { - SAR-400, Chapter 17, "Management, } \\
\text { Organization and Institutional Safety } \\
\text { Provisions" }\end{array}$ & \\
\hline
\end{tabular}


INL/EXT-10-19054

Revision 0

\section{APPENDIX B. DESIGN APPROACH TO ADDRESS DOE ORDER 420.1B DESIGN REQUIREMENTS}

DOE-STD-1189-2008, Appendix I, Table B-1 below provides a comparative listing of major regulatory requirements for identified SSCs and the project implementing design document. Similarly, DOE O 420-1B, Chapter V, Attachment 2, Table B-2 below provides a listing of the top-level design criteria from DOE O 420.1B, "Facility Safety," and DOE G 420.101,"Nonreactor Nuclear Safety Design Criteria and Explosives Safety Criteria Guide for use with DOE O 420.1, Facility Safety," and their associated applicability to RH LLW disposal project. Table B-2 also provides cross-reference of these criteria to the respective project or site implementing document.

There are currently no safety-related SSCs for the RH LLW disposal facility project. The safetysignificant SSCs for the RH LLW disposal facility project are:

- Vault shield plugs

- Waste container transfer shielding system

- Robust transportation package.

As discussed in Section 4.3, the primary safety function performed by these safety-significant SSCs is to "prevent/mitigate direct radiation exposure either during vault storage, waste container handling operations, and transportation package handling operations." The primary functional requirement for all three of these safety-significant SSCs is to "provide sufficient thickness of shielding media to reduce external dose to acceptable level." 

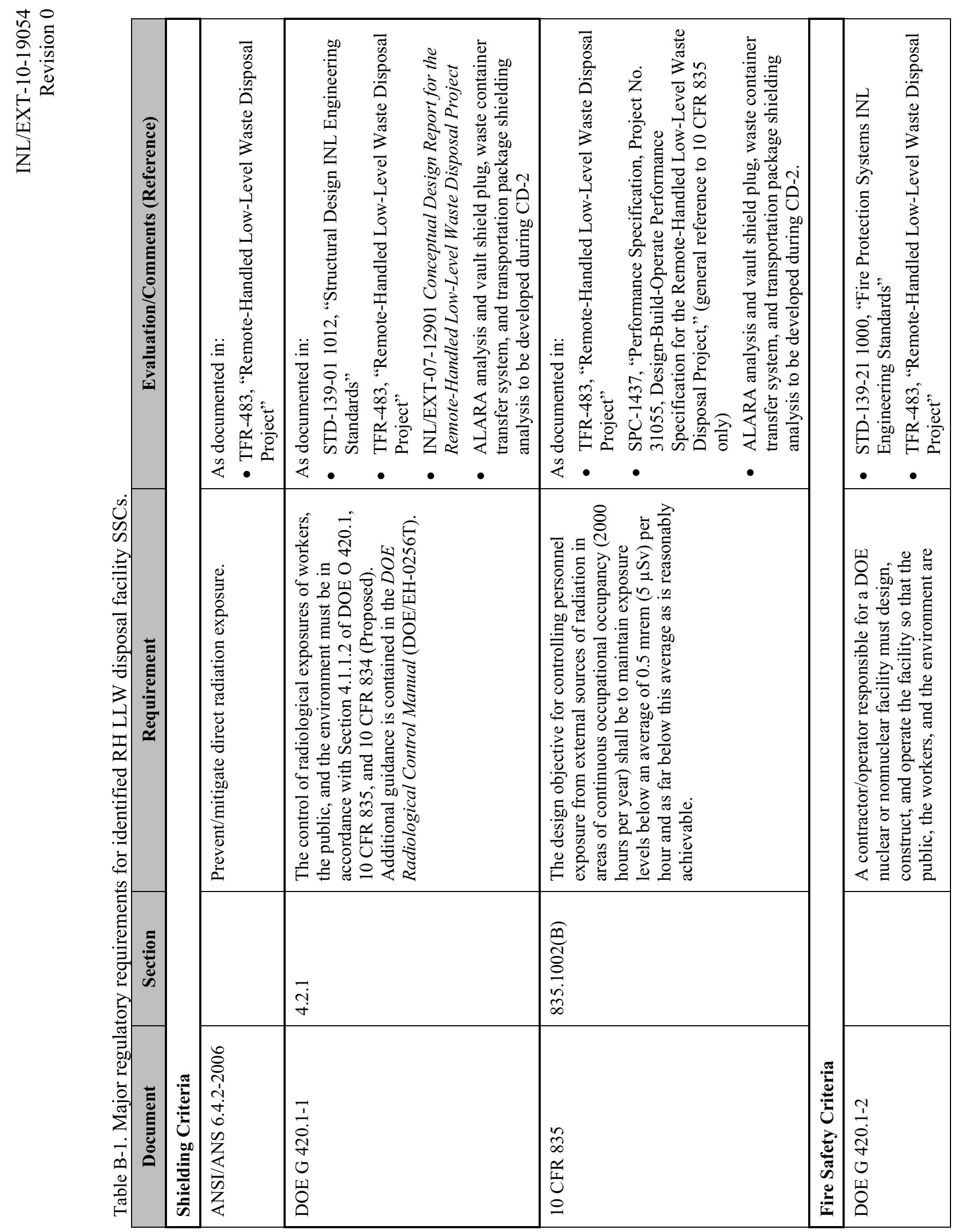

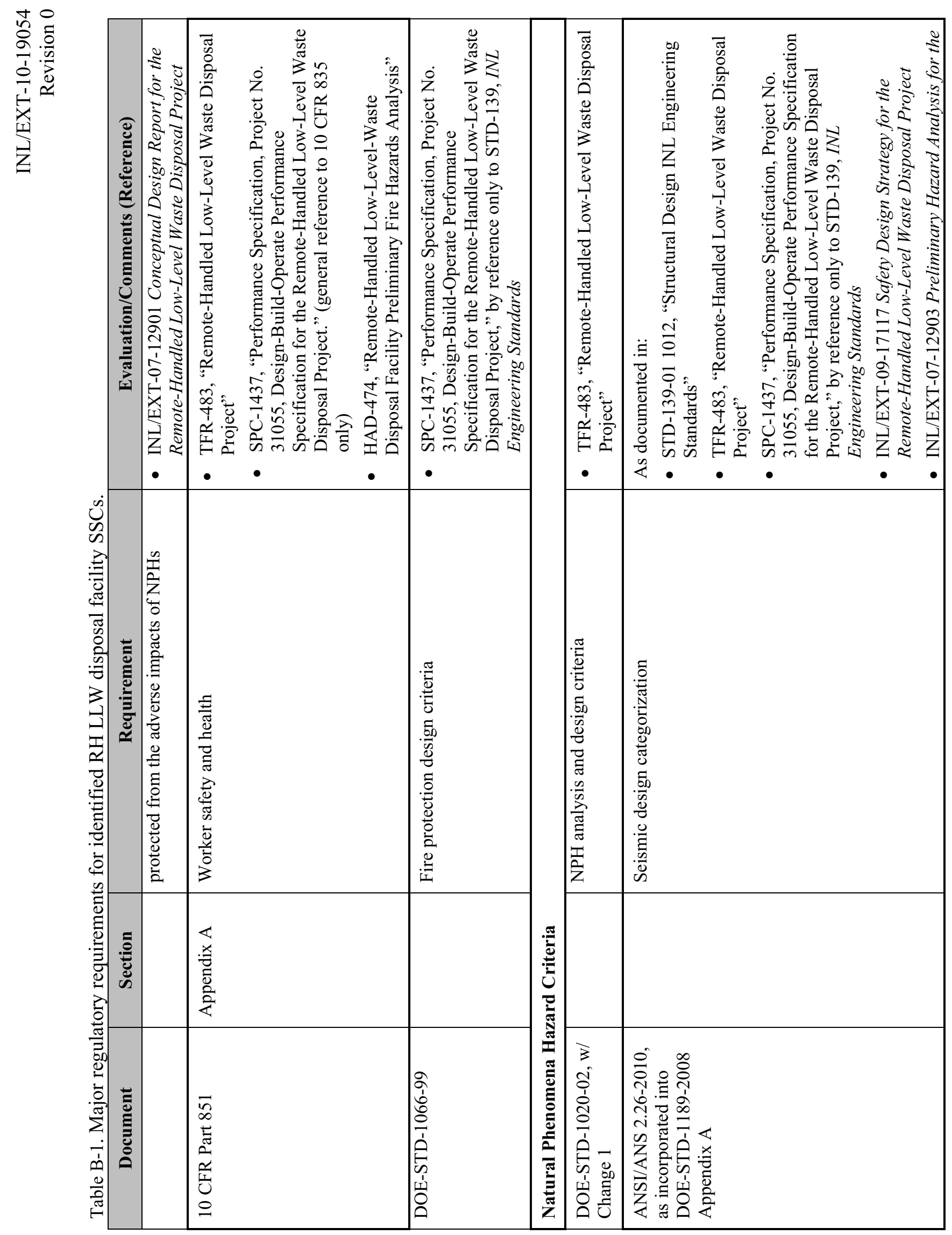

$\tilde{n}$ 

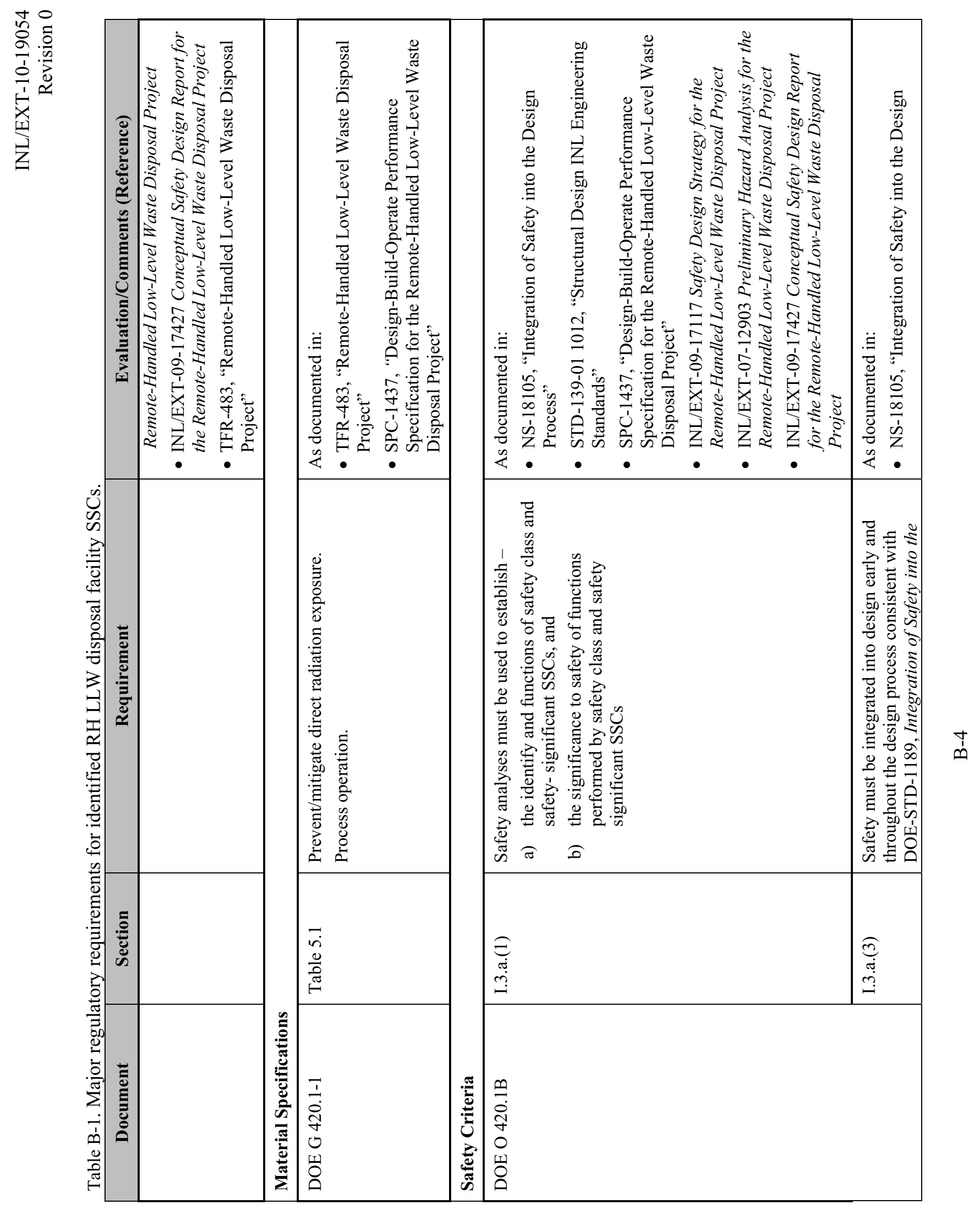

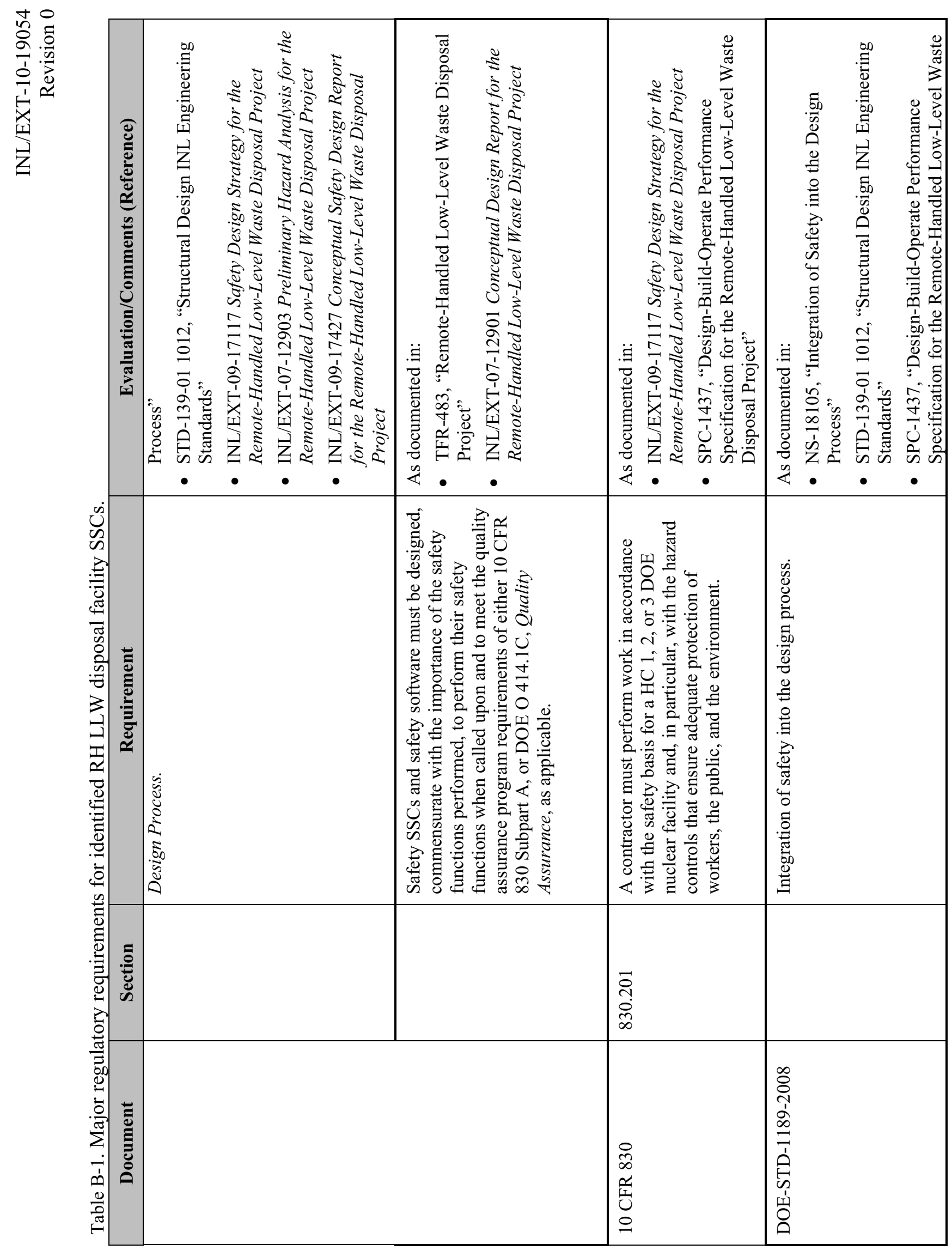

n 

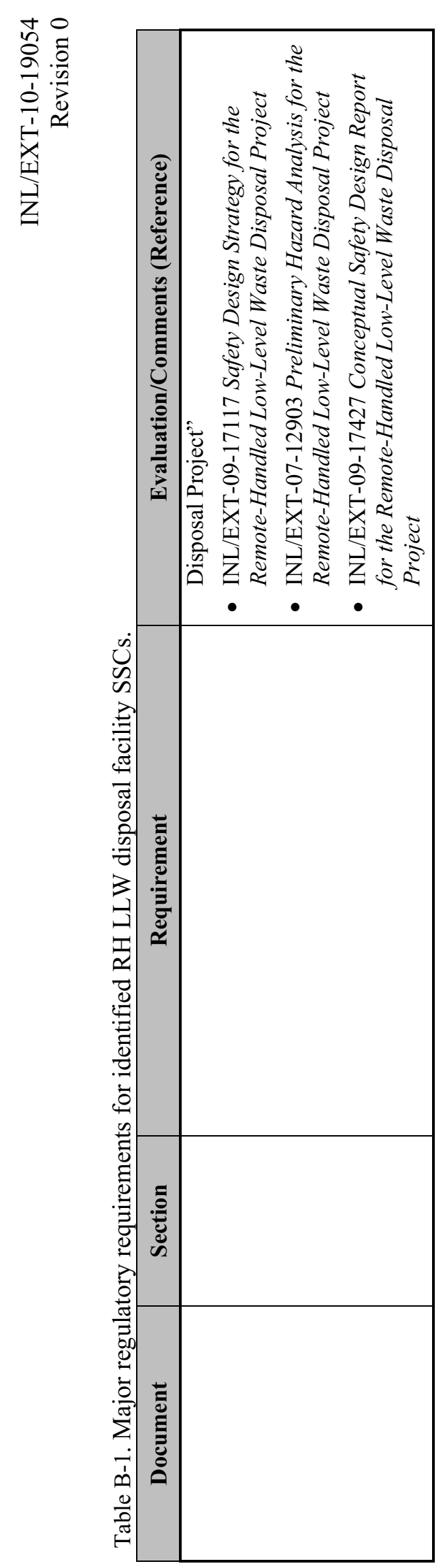

மீ 

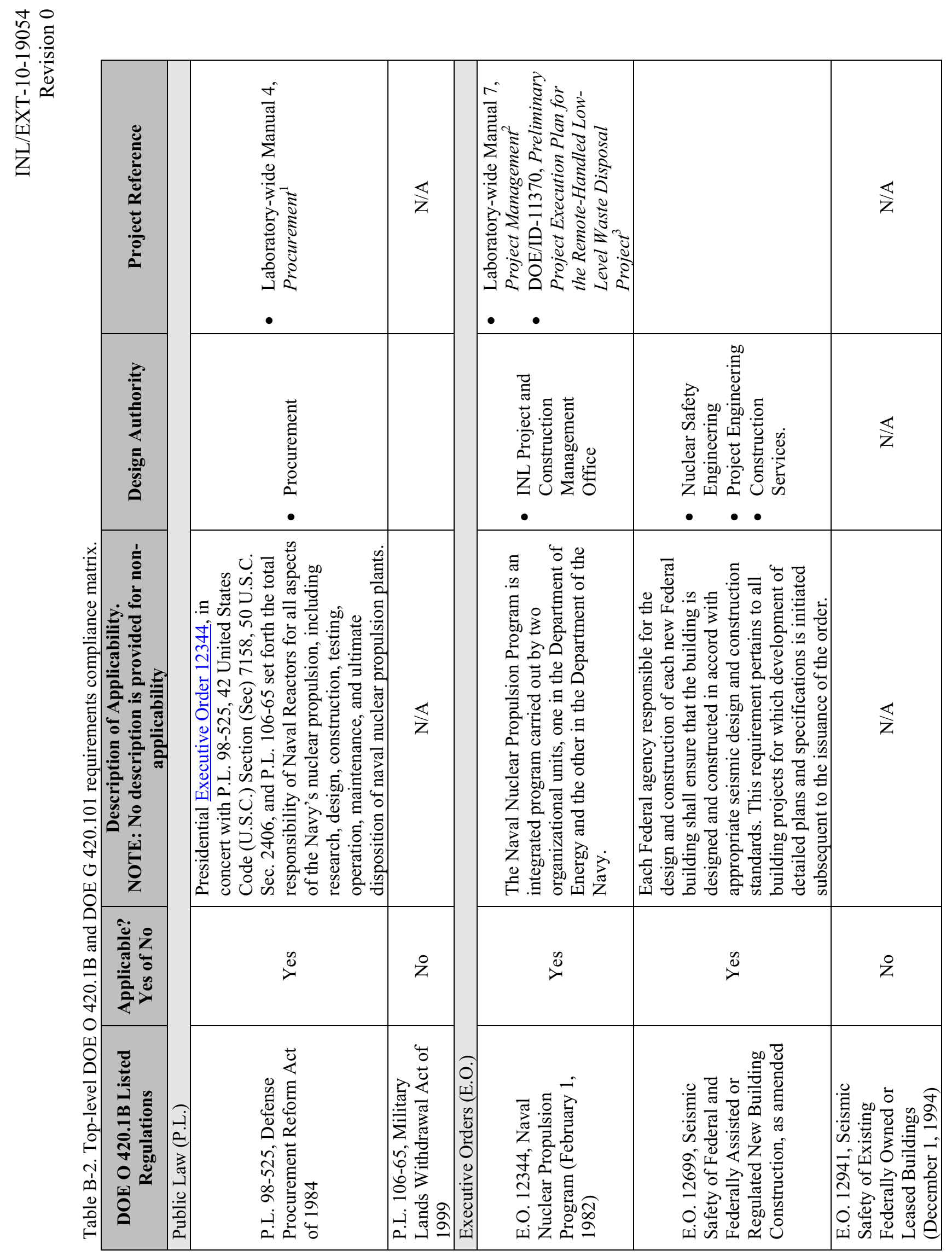

ñ 

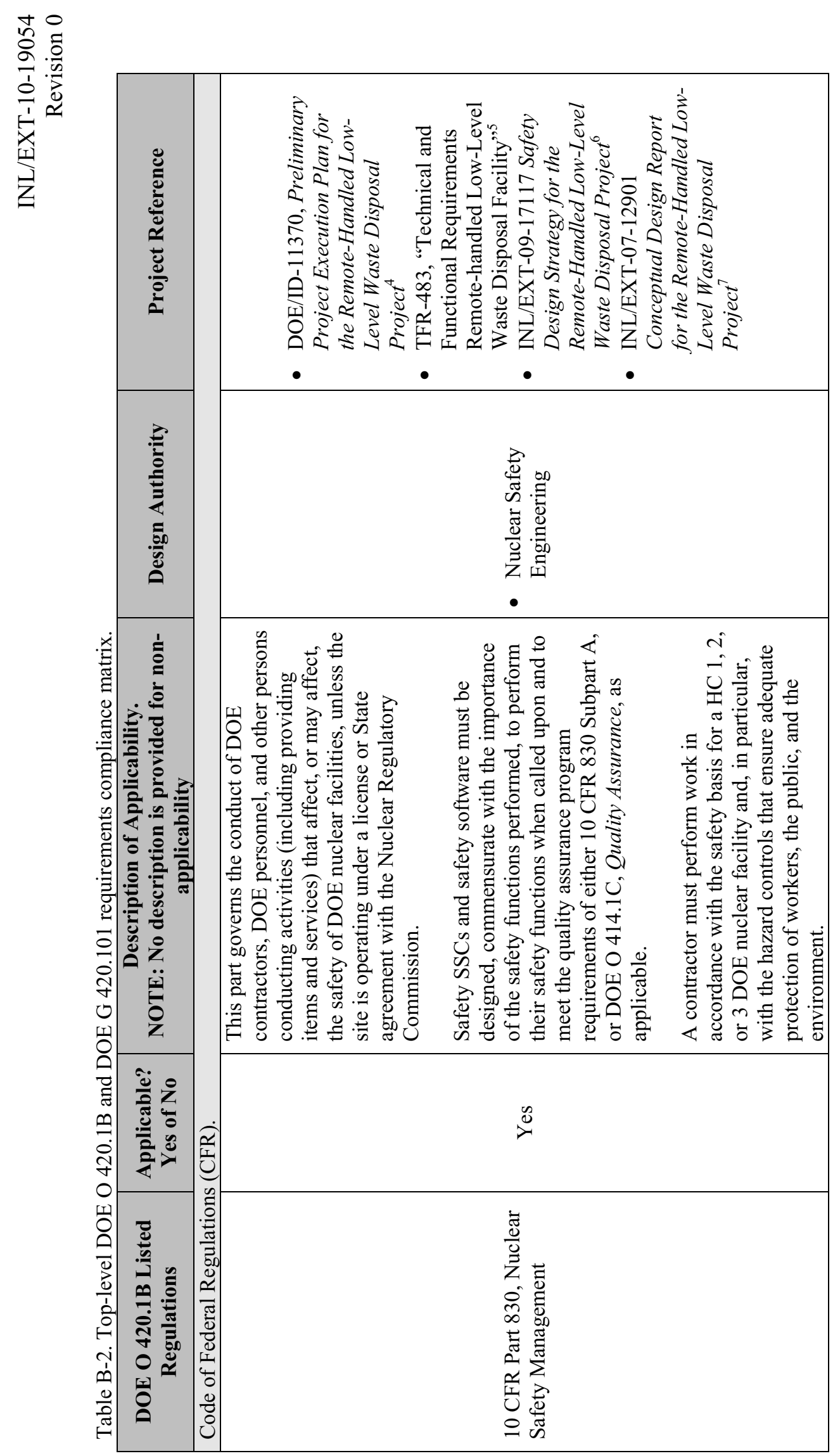


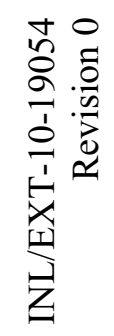

\begin{tabular}{|c|c|c|c|}
\hline & 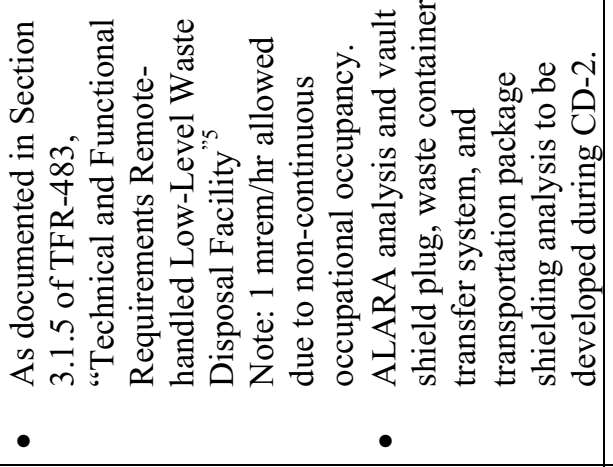 & 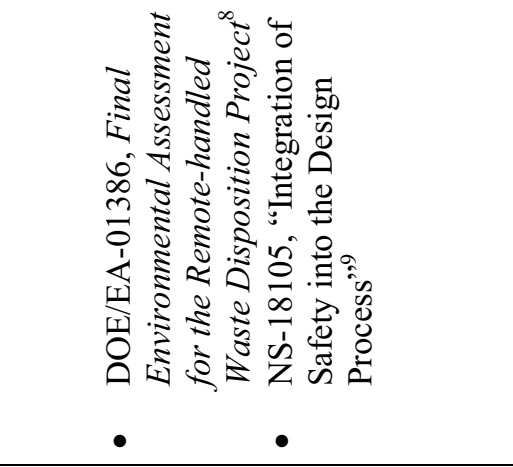 & 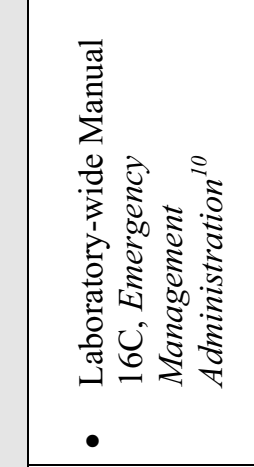 \\
\hline & 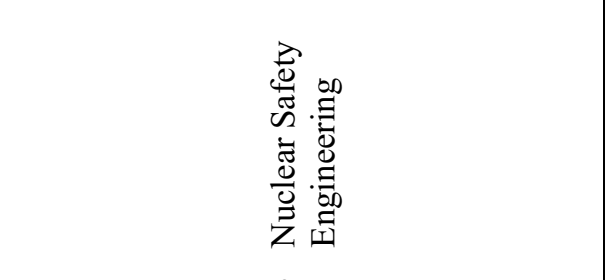 & 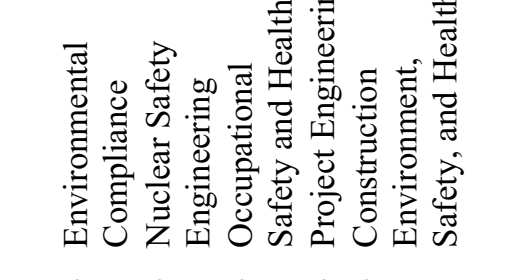 & \\
\hline 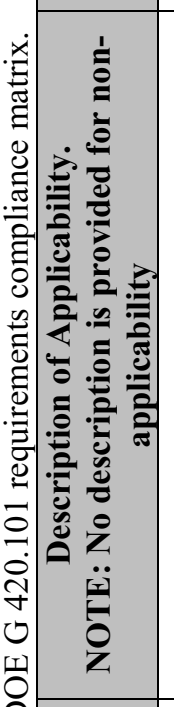 & 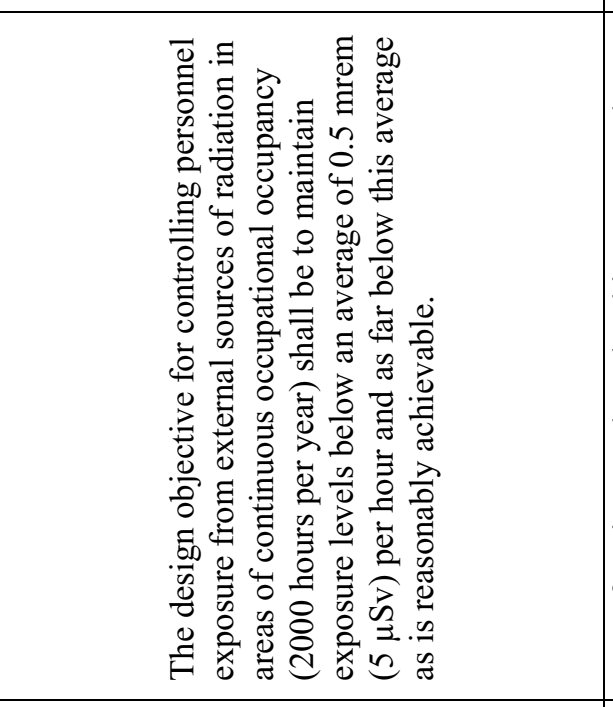 & 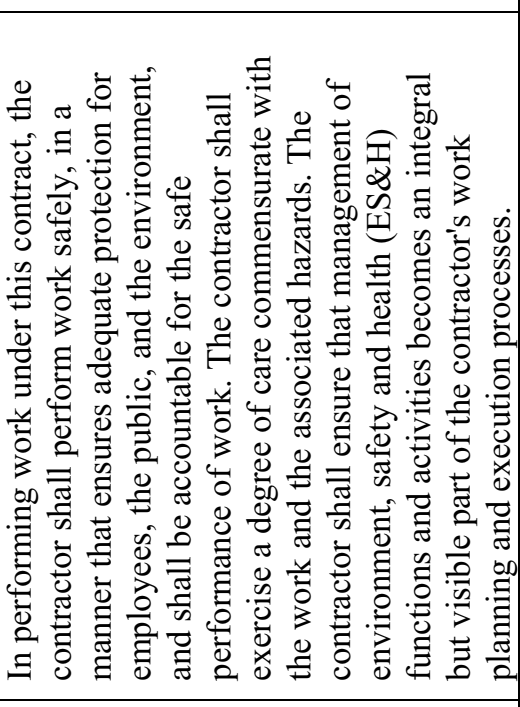 & 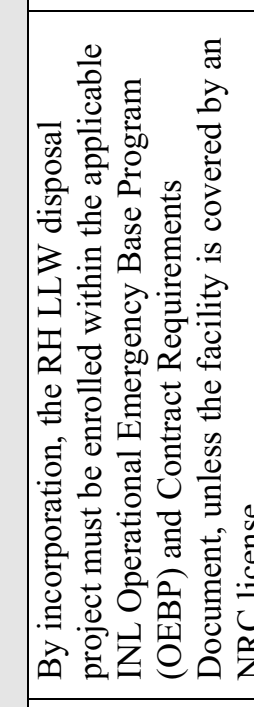 \\
\hline 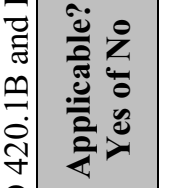 & $\overbrace{0}^{8}$ & $\check{\mathscr{S}}$ & $=$ \\
\hline t & 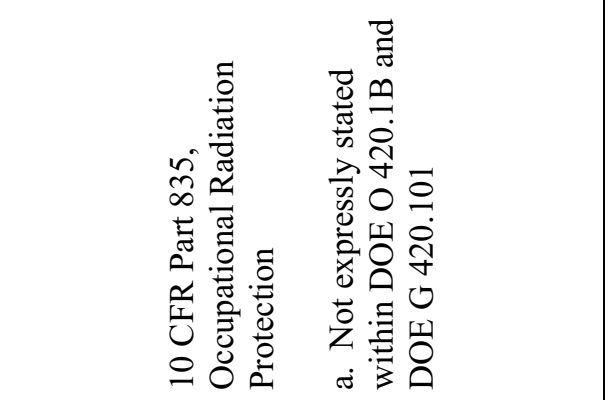 & 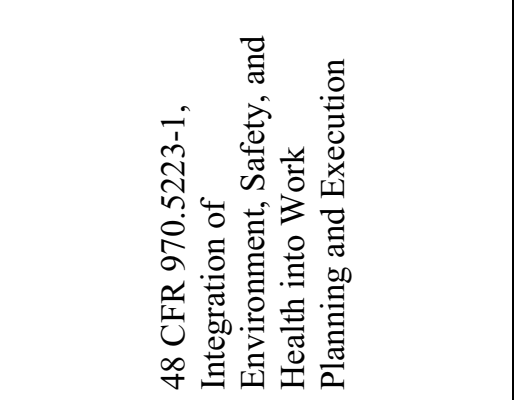 & 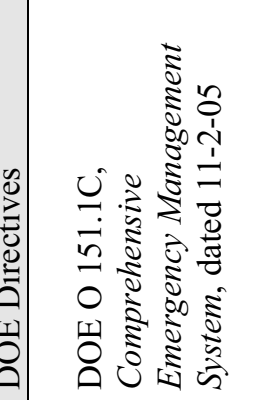 \\
\hline
\end{tabular}

के 

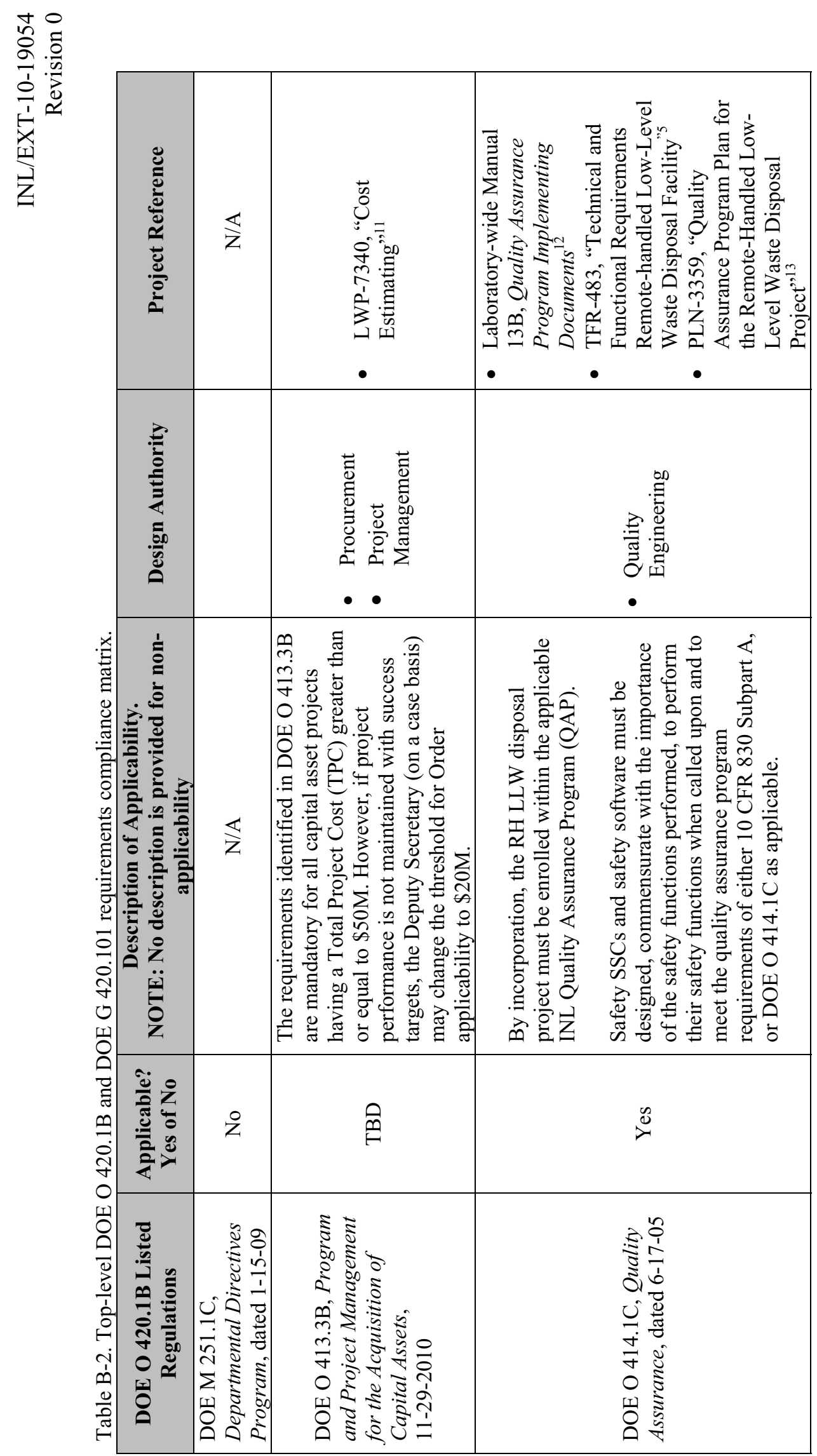

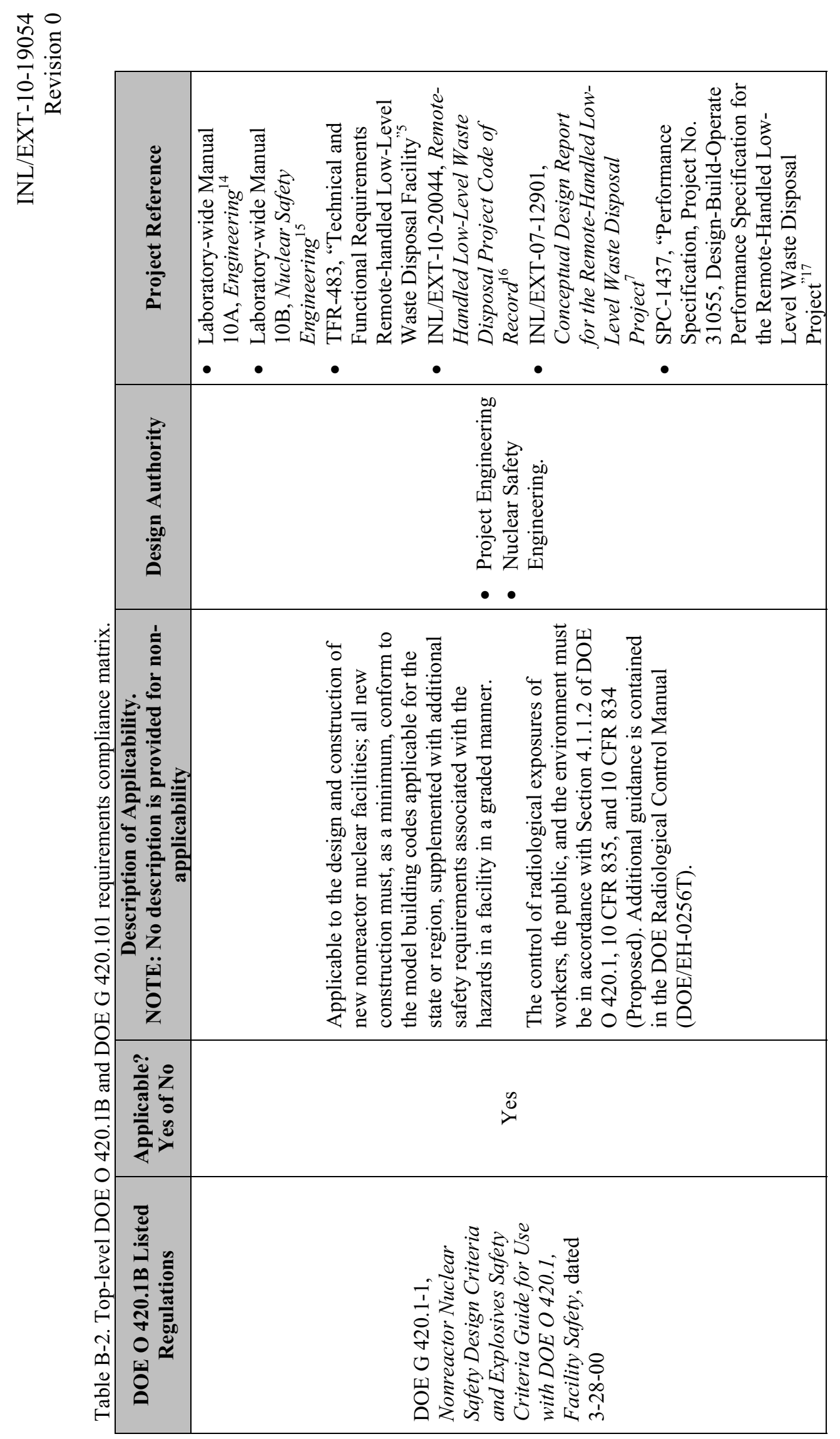

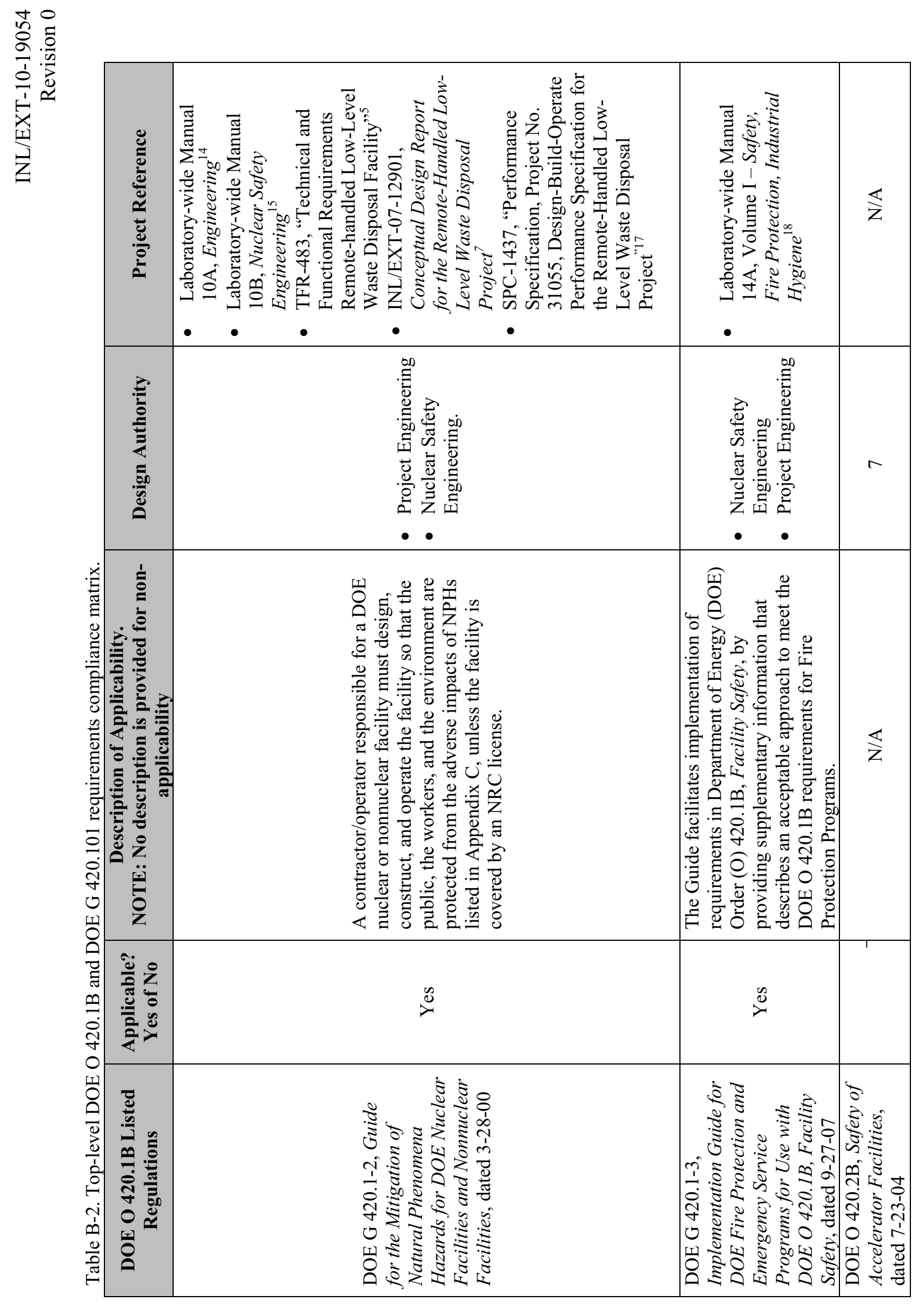

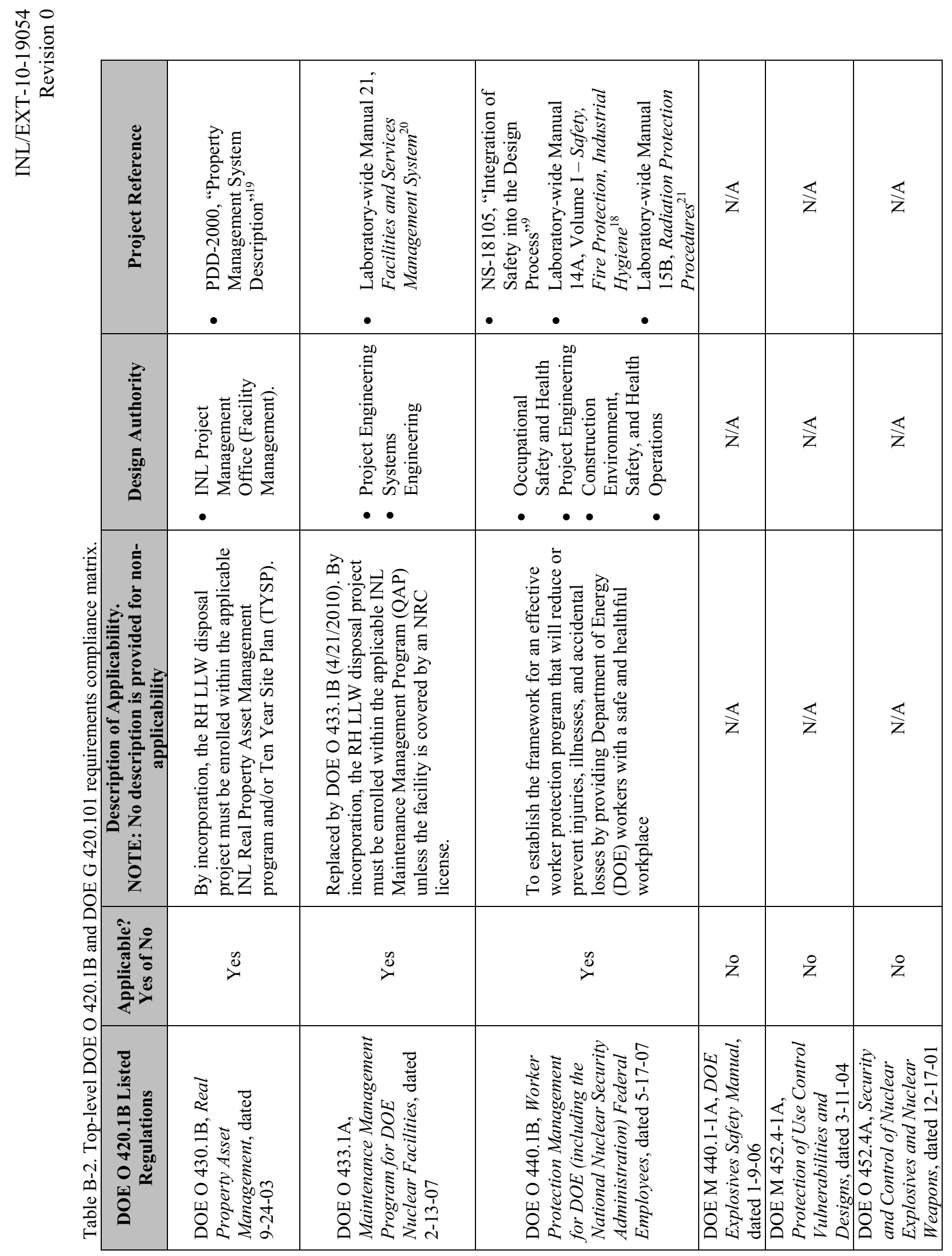

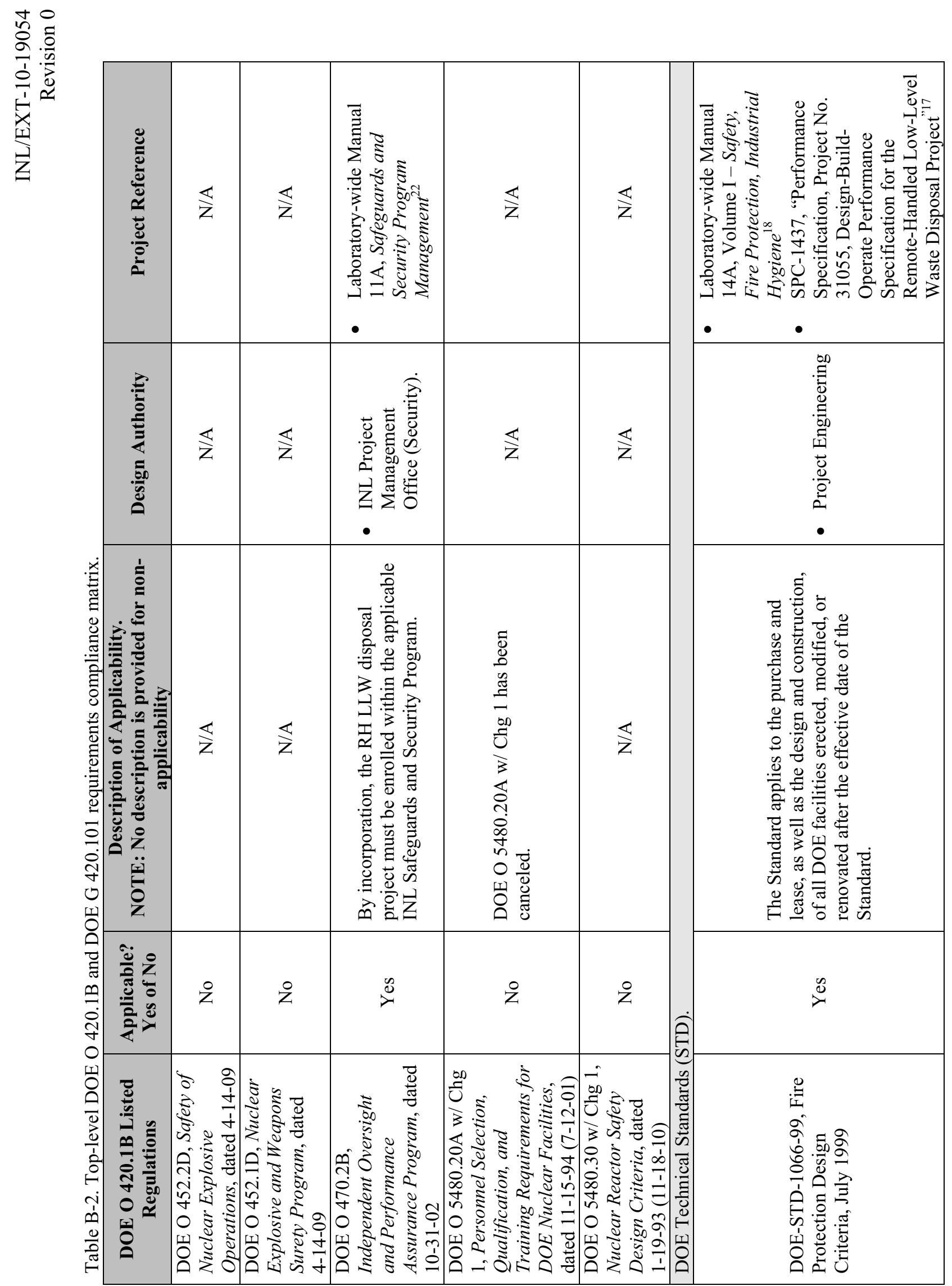

$\frac{\nabla}{D}$ 

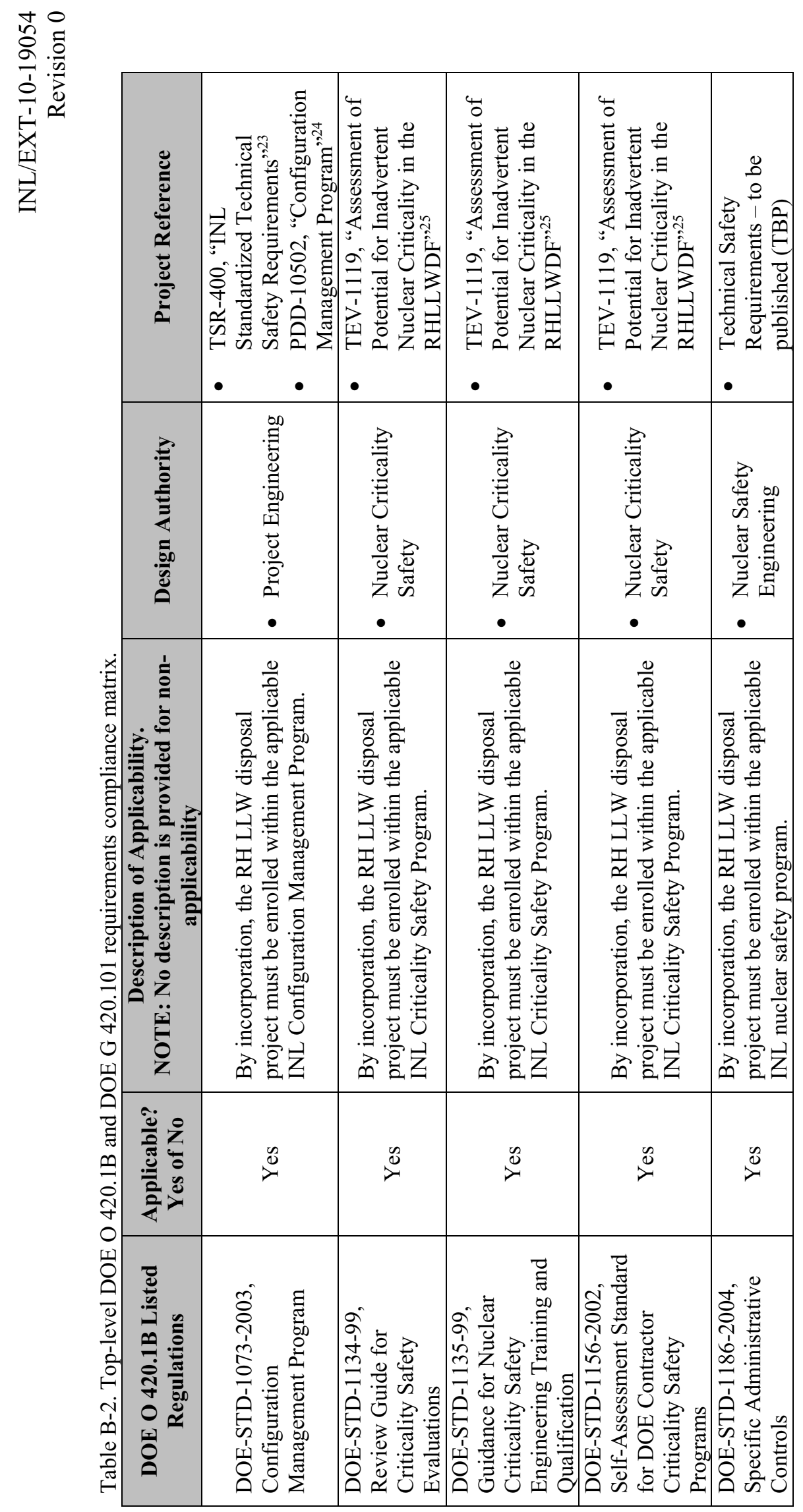

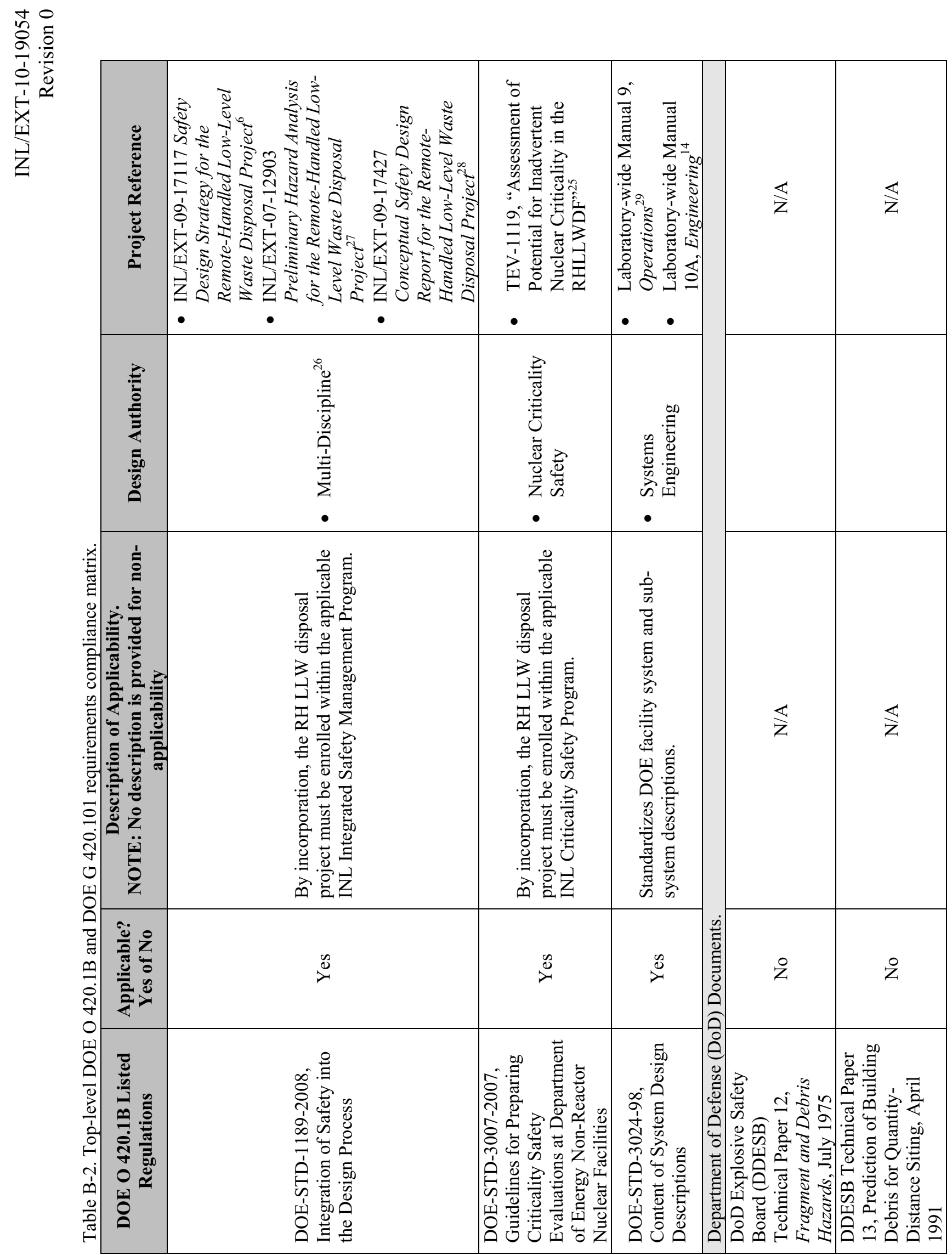

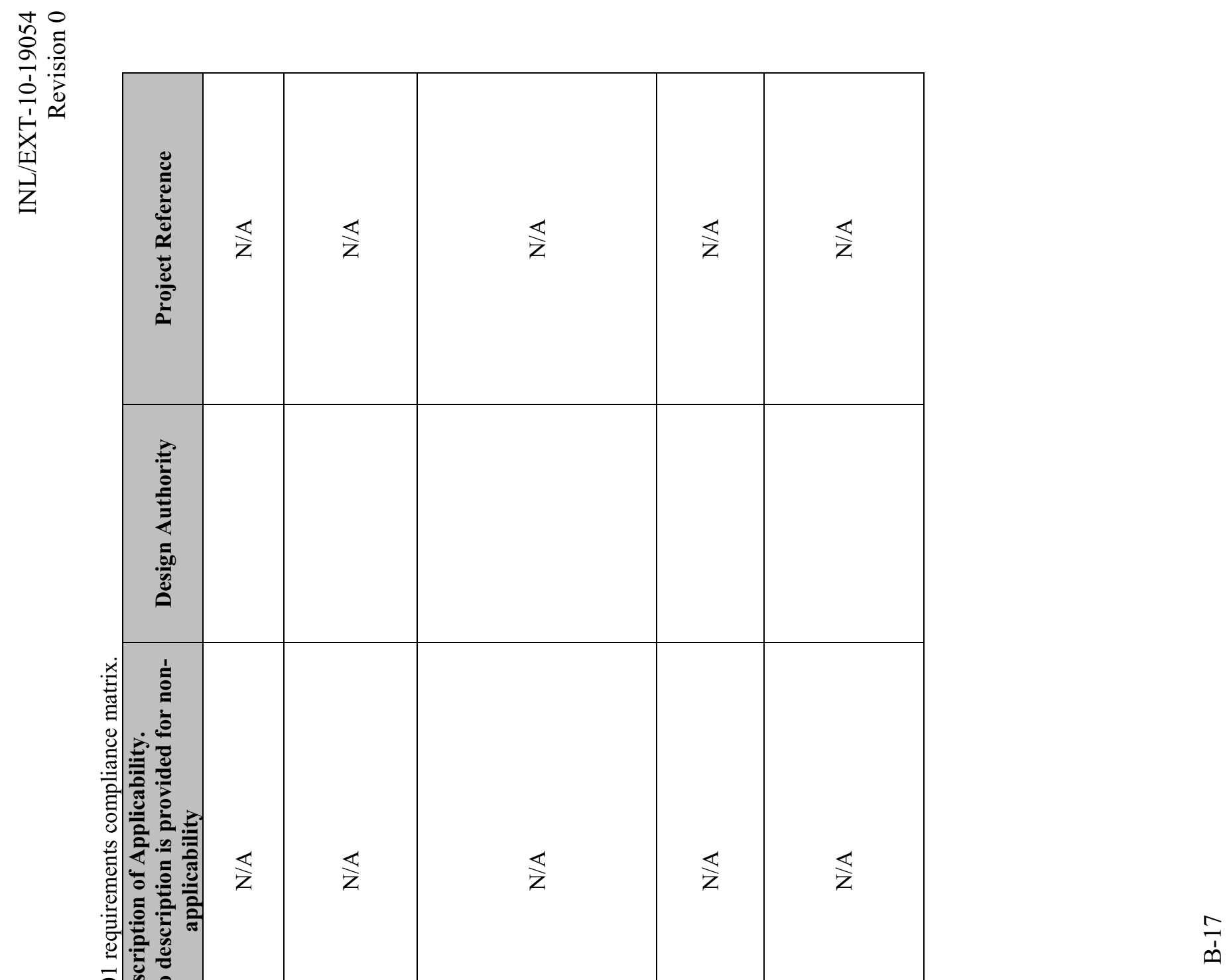

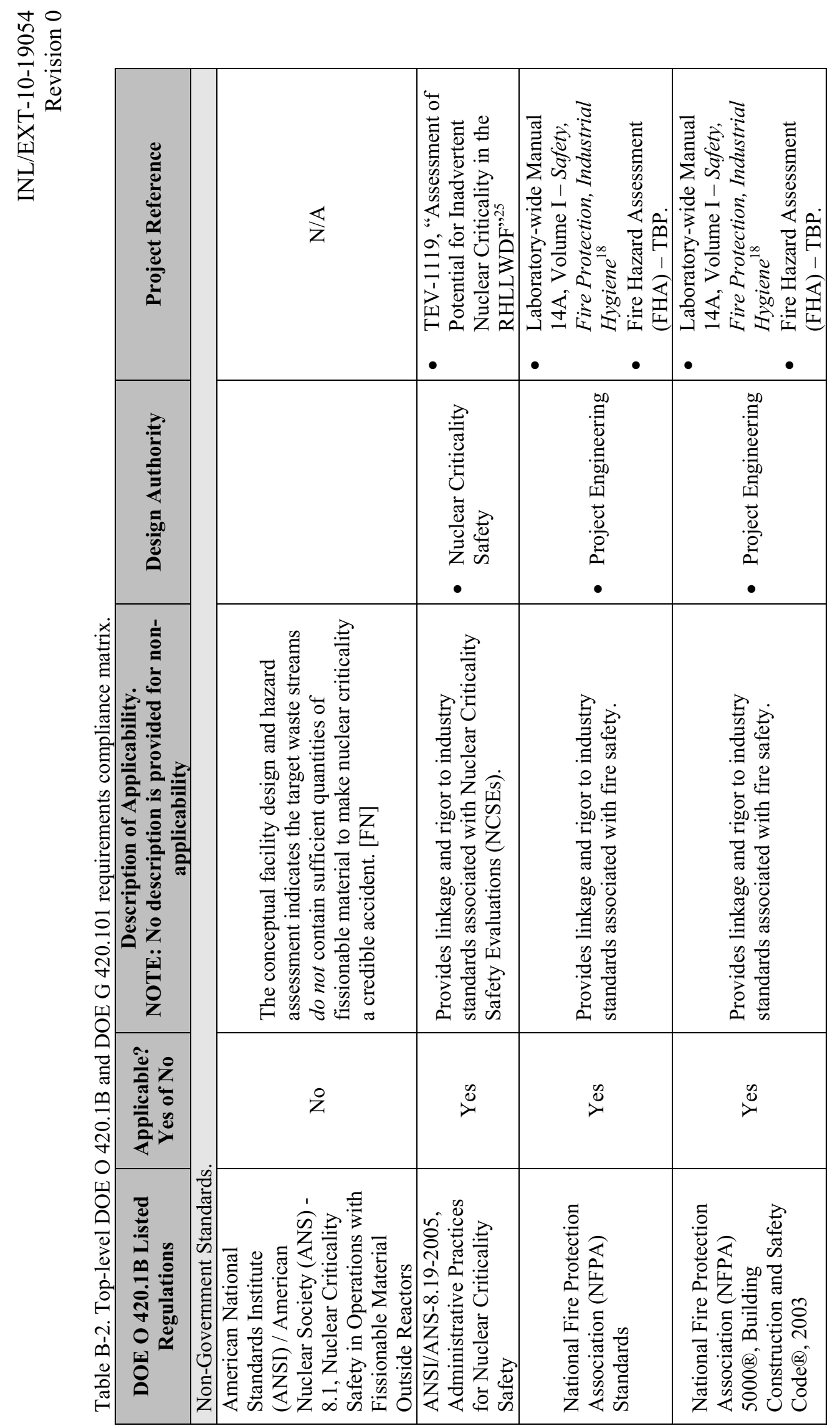
INL/EXT-10-19054

Revision 0

\section{REFERENCES}

1. TOC-34, "Manual 4 - Procurement," Rev. 129, November 2011.

2. TOC-6, "Manual 7 - Project Management,” Rev. 164, January 2012.

3. DOE/ID-11370, Preliminary Project Execution Plan for the Remote-Handled Low-Level Waste Disposal Project May 2011.

4. DOE/ID-11370, Preliminary Project Execution Plan for the Remote-Handled Low-Level Waste Disposal Project, Rev. 6, May 2011.

5. TFR-483, "Technical and Functional Requirements Remote-handled Low-Level Waste Disposal Facility,” Rev. 4, January 2012.

6. INL/EXT-09-17117 Safety Design Strategy for the Remote-Handled Low-Level Waste Disposal Project, Rev. 3z, October 2010 $\underline{\text { July } 2012 .}$

7. INL/EXT-07-12901 Conceptual Design Report for the Remote-Handled Low-Level Waste Disposal Project, Rev. 4, March 2011.

8. DOE/EA-01386, Final Environmental Assessment for the Remote-handled Waste Disposition Project, February 2009.

9. NS-18105, "Integration of Safety into the Design Process," current revision.

10. TOC-53, "Manual 16C- Emergency Management Administration, Rev. 102, March 2012.

11. LWP-7340, “Cost Estimating,” Rev. 5, February 2012.

12. TOC-9, "Manual 13B - Quality Assurance Program Implementing Documents," Rev. 215, January 2012.

13. PLN-3359, "Quality Assurance Program Plan for the Remote-Handled Low-Level Waste Disposal Project," Rev. 3, March 2012.

14. TOC-7, “Manual 10A - Engineering,” Rev. 163, February 2012.

15. TOC-40, "Manual 10B - Nuclear Safety Engineering,” Rev. 92, February 2012.

16. INL/EXT-10-20044, Remote-Handled Low-Level Waste Disposal Project Code of Record, Rev. 2, April 2011.

17. SPC-1437, "Performance Specification, Project No. 31055, Design-Build-Operate Performance Specification for the Remote-Handled Low-Level Waste Disposal Project," Rev. 0, January 2012.

18. TOC-647, "Manual 14A, Volume I - Safety, Fire Protection, Industrial Hygiene,” Rev. 98, December 2011; TOC-648, "Manual 14A, Volume II - Safety, Fire Protection, Industrial Hygiene - Table of Contents," Rev. 34, February 2012. 
19. PDD-2000, "Property Management System Description," Rev. 3, November 2009.

20. TOC-789, "Manual 21 - Work Management,” Rev. 35, March 2012.

21. TOC-5, "Manual 15B - Radiation Protection Procedures,” Rev. 204, January 2012.

22. TOC-1, "Manual 11A - Safeguards and Security, Program Management," Rev. 86, February 2012.

23. TSR-400, "INL Standardized Technical Safety Requirements," current revision.

24. PDD-10502, “Configuration Management Program,” Rev. 1, February 2009.

25. TEV-1119, "Assessment of Potential for Inadvertent Nuclear Criticality in the RHLLWDF," Rev. 0, December 2010

26. NS-18105, “Integration of Safety into the Design Process,” Rev. 0, October 2009.

27. INL/EXT-07-12903 Preliminary Hazard Analysis for the Remote-Handled Low-Level Waste Disposal Project, Rev. 2, February 2010.

28. INL/EXT-09-17427 Conceptual Safety Design Report for the Remote-Handled Low-Level Waste Disposal Project, Rev. 0, February 2010.

29. TOC-46, “Manual 9 - Operations,” Rev. 133, January 2012. 